\title{
7. PALEOCEANOGRAPHY AND BIOSTRATIGRAPHY OF PALEOGENE RADIOLARIANS FROM THE NORWEGIAN-GREENLAND SEA ${ }^{1}$
}

\author{
Donna Meyerhoff Hull ${ }^{2}$
}

\begin{abstract}
Eocene and Oligocene radiolarians were recovered from two sites on Ocean Drilling Program (ODP) Leg 151. Early Oligocene to early late Oligocene radiolarians have been extracted from material cored at Site 908 on the Hovgård Ridge (Fram Strait). Although rare and only moderately preserved, these assemblages represent the northernmost occurrence of radiolarians recovered by either the Deep Sea Drilling Project or ODP thus far. Site 913 on the East Greenland margin has yielded a sequence of moderately diverse middle Eocene to earliest Oligocene radiolarians. In total, $\sim 75$ species have been documented herein from both sites.

Previous radiolarian biostratigraphies developed for the Norwegian-Greenland Sea were used as an initial basis for Leg 151 age dating. However, complications introduced by Leg 38 spot-coring techniques and radiolarian endemism are highlighted by Site 913 material that does not fit easily into either of the previous biostratigraphic zonations proposed for this region. Consequently, age determinations are based in part on comparison of Site 913 with Leg 38 sites as well as calibration of radiolarian events with other microfossil groups (diatoms, silicoflagellates, and dinoflagellates) present in Hole 913B. The combined stratigraphies suggest the presence of the Eocene/Oligocene boundary in the uppermost part of the biosiliceous sequence at Site 913. The uppermost part of this interval is characterized by the dominance of robust radiolarian groups, broken radiolarian tests, rare diatoms and increased reworking of radiolarians and dinoflagellates. These changes are interpreted as evidence for increased bottomwater circulation associated with radiolarian blooms at or just above the Eocene/Oligocene boundary. These findings concur with previous studies indicating increased bottomwater circulation in the North Atlantic during this same period of geologic time.
\end{abstract}

\section{INTRODUCTION}

During Leg 151 of the Ocean Drilling Program (ODP), seven sites were drilled in the Norwegian-Greenland Sea and Arctic Ocean proper. Paleogene biosiliceous sediment bearing radiolarians were cored at two of these sites, Site 908 in the Fram Strait and Site 913 on the East Greenland margin (Fig. 1; Myhre, Thiede, Firth, et al., 1995). Although many of the goals of the cruise were directed towards Neogene studies and the initiation of deep-water exchange with the Arctic Ocean through the Fram Strait (the northern "Arctic gateway"), emphasis has also been placed on developing an understanding of the warmer climatic period of the Early Tertiary. Eocene and Oligocene radiolarians recovered on this cruise provide insight to this period of time from areas of the Norwegian-Greenland Sea that had not been deeply cored prior to Leg 151 .

Site 908 was drilled on the Hovgård Ridge in the southern part of the Fram Strait (Fig. 1). This site was selected to determine the age and lithology of sediments on the ridge crest and to study the subsidence and water-mass exchange histories of the area. Mapped as a fracture zone by Johnson and Eckhoff (1966), the Hovgård Ridge consists of a western ridge block and an eastern seamount-like feature (Eldholm and Myhre, 1977) along the northern boundary of the Boreas Basin. Prior to Anomaly 13 time ( 33 to $34 \mathrm{Ma}$ in Cande and Kent, 1992; approximately at the Eocene/Oligocene boundary), the Fram Strait is thought to have been closed (Fig. 1). During Anomaly 13 time, the poles of rotation changed in the Norwegian-Greenland Sea, and rifting was initiated between Greenland and Svalbard (Tal-

'Thiede, J., Myhre, A.M., Firth, J.V., Johnson, G.L., and Ruddiman, W.F. (Eds.), 1996. Proc. ODP, Sci. Results, 151: College Station, TX (Ocean Drilling Program).

${ }^{2}$ Programs in Geosciences, The University of Texas at Dallas, P.O. Box 830688 Richardson, TX 75083-0688,U.S.A.dmhull@utdallas.edu wani and Eldholm, 1977; Sundvor and Eldholm, 1979). Myhre et al. (1982) and Myhre and Eldholm (1988) have suggested that the Hovgård Ridge split off from the Svalbard margin during this time, and moved as a small microcontinent towards its present position. Other workers (Vogt, 1986; Grønlie and Talwani, 1982) have argued that high gravity and magnetic anomalies on the Hovgård Ridge are more consistent with gabbroic bodies typical of oceanic crust, rather than continental crust. Regardless, water exchange through the initial opening of the Fram Strait during the Oligocene is thought to be controlled by the gradual widening of the Fram Strait and submergence of the Yermak Plateau (Thiede et al., 1990b), and although shallow water exchange may have begun with the early phase of the opening, tectonic models (e.g., Kristoffersen, 1990; Lawver et al., 1990) and sedimentological evidence from deep coring (Myhre, Thiede, Firth et al., 1995) do not support deep-water exchange through the Fram Strait prior to the late Miocene.

Early Oligocene to late Miocene radiolarians were recovered in the Fram Strait from Hole 908A. Late Miocene radiolarians are present only in Core 151-908A-20X; early to early late Oligocene radiolarians are present in biosiliceous sediments underlying an unconformity at the base of Core 151-908A-20X ( 185 meters below sea floor [mbsf]). They continue sporadically down to Core 151-908A$34 \mathrm{X}$ ( $317 \mathrm{mbsf}$ ), are rare and moderately to very poorly preserved. High sedimentation rates and the taxonomic composition of diatoms and silicoflagellate assemblages suggest a neritic (outer) depositional environment, a setting that is probably accountable for the poor representation of radiolarians at this site. Nonetheless, these assemblages represent the most northerly occurrence of Paleogene radiolarians recovered by either the Deep Sea Drilling Project (DSDP) or ODP thus far.

Site 913 is located on the eastern margin of Greenland in the western portion of the Greenland Basin (Fig. 1). The drill site is located on crust that formed during symmetric seafloor spreading along the 


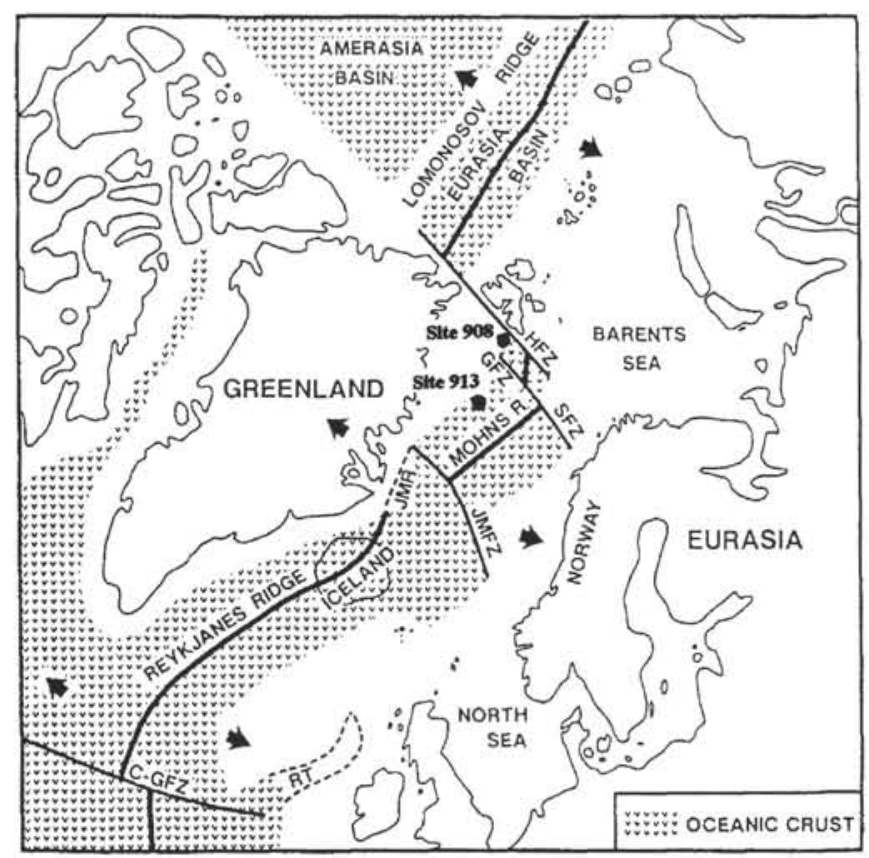

Figure 1. Plate-tectonic reconstruction of the Norwegian-Greenland Sea at the Eocene/Oligocene boundary. Approximate positions of Sites 908 and 913 indicated. C-GFZ $=$ Charlie-Gibbs Fracture Zone; RT = Rockall Trough; $\mathrm{JMFZ}=$ Jan Mayen Fracture Zone; SFZ = Senja Fracture Zone; HFZ = Hornsund Fault Zone; GFZ = Greenland Fracture Zone. Modified from Myhre et al., 1992.

Mohns Ridge, beginning in approximately Anomaly 24B time (53$55 \mathrm{Ma}$; Talwani and Eldholm, 1977; Eldholm and Thiede, 1980). Hole $913 \mathrm{~B}$ yielded a thick succession of brightly colored, laminated biosilica-rich clays and oozes, composed of diatoms, radiolarians, silicoflagellates, and dinoflagellates. This sedimentary sequence is a reflection of one of the oldest environments on the western side of the Cenozoic Norwegian-Greenland Sea, which was at that time a very young and relatively narrow basin (Fig. 1). Potential paleoceanographic influences on the Eocene and Oligocene floras and faunas have been discussed by several workers (e.g., Berggren and Schnitker, 1983; Kaminski, 1988; Thiede et al., 1989) and include water exchange with the North Atlantic across shallow interruptions in the Greenland-Scotland Ridge, across epicontinental seaways, with the North Sea through deeper water connections, and with the Arctic Ocean.

Radiolarians are present from Cores 151-913B-23R to 32R (453.1 to $542.5 \mathrm{mbsf}$ ); they are most abundant and best preserved from the top of Core 151-913B-24R to the middle of Core 151-913B-27R ( 494 mbsf). Below Section 151-913B-27R-3, radiolarians are rare and poorly preserved, but consist of a few biostratigraphically important species. Efforts to use radiolarians in resolving biostratigraphic and paleoceanographic questions of the Norwegian-Greenland Sea have been challenging at the very least. Stratigraphic marker species used for tropical, subtropical, temperate, and subantarctic radiolarian zonations are absent from the Norwegian-Greenland Sea. Consequently, two separate zonations, one by Bjørklund (1976) and a second by Dzinoridze et al. (1978), were proposed for the Paleogene of the Norwegian-Greenland Sea based on Leg 38 data. Both zonations were the first attempts to zone Eocene and Oligocene radiolarian assemblages and for many years they have provided workers with an initial stratigraphic base. However, problems have been encountered in applying either zonation to Leg 151 material because: (1) spot-coring of the Leg 38 material resulted in a succession of radiolarian zones that may be stratigraphically ordered, but which include many zones that have undefined boundaries that are questionably calibrated with the geologic time scale; (2) some of the key stratigraphic markers used for Leg 38 do not occur at Sites 908 or 913; (3) there are significant differences in taxonomic concepts between Bjørklund and Dzinoridze et al., resulting in difficulties comparing the zonations; and (4) although short intervals of the Leg 151 material provide wellpreserved assemblages, good preservation and stratigraphic completeness are not extensive enough to answer all of the questions raised by the Leg 38 material. Magnetostratigraphic studies of Site 913 have not been successful; dinoflagellate, silicoflagellate, and diatom studies help calibrate the Leg 151 material, but are complicated by similar problems.

In this report, therefore, emphasis is placed on: (1) describing the faunas discovered at Sites 908 and 913 (Tables 1, 2; Plates 1-8); (2) noting variations in the assemblages which may be related to paleoclimatic and/or paleoceanographic changes; and (3) noting the precise stratigraphic order in which species events occur both within the cores and relative to the stratigraphies provided by dinoflagellates, diatoms, and silicoflagellates (Fig. 2). Also, other occurrences of these species are noted both within the Norwegian-Greenland Sea and where possible in other sections globally (e.g., Labrador Sea, Antarctica, Siberia and California; Table 3), with the goal of creating a broader view of the full possible stratigraphic and paleogeographic range of these taxa.

\section{METHODS}

Two sets of samples were analyzed in preparation for this report. Approximately 200 samples were collected on board according to the preapproved request. Smear slides were prepared for each sample at The University of Texas at Dallas, after which the remainder of the sediment was broken down using a solution of sodium pyrophosphate, hydrogen peroxide, and water (methodology of Sanfilippo et al., 1985). Because high-latitude northern hemisphere radiolarians include many small species, residues were sieved through $38 \mu \mathrm{m}$ and larger sieves. Most samples had to be processed at least twice to remove most of the clays, although a few samples from Site 913 and all samples from Site 908 required three to five processing sessions.

After the initial set was analyzed, additional samples ( 40) were requested and collected by the author at the Bremen Core Repository (Bremen, Germany) to fill in gaps where more data were desired or needed. These samples were processed using the method of J.-P. Caulet (pers. comm., 1994), which uses two separate solutions - one, a mixture of water and hydrogen peroxide and two, a mixture of ammonium liquid and water-plus brief, gentle boiling, and extended soaking periods to attempt to disaggregate fossils and clays with less mechanical working of the sample in the laboratory. In general, results showed that this method does increase abundance and diversity of radiolarians in the samples by reducing the amount of breakage, but it does not remove clays from the internal radiolarian tests as well as the previous method.

Slide mounts were prepared using Canada Balsam and Permount mounting mediums. A randomly sampled mixture of water and residue was extracted from each sample by pipette and spread (strewn) onto a clean glass slide. After drying, two to three drops of xylene were placed on the slides to reduce air bubbles. After applying the mount and glass cover slips, the strewn slides were slowly heated for one to three days. Visual radiolarian studies were conducted using a Nikon transmitted light optical microscope at $50 \times$ to $250 \times$ magnification. Although black and white photographs were made of some specimens, the majority of the fauna was studied via video-print images taken at the Scripps Institute Microfossil Reference Center. The use of a video printer allows for a greater number of pictures to be taken in a much shorter time, allowing for maximum study of the full diversity of the fauna present. After selecting the more important or 
Table 1. Preservation, abundance, and occurrence of radiolarians in Hole 908A.

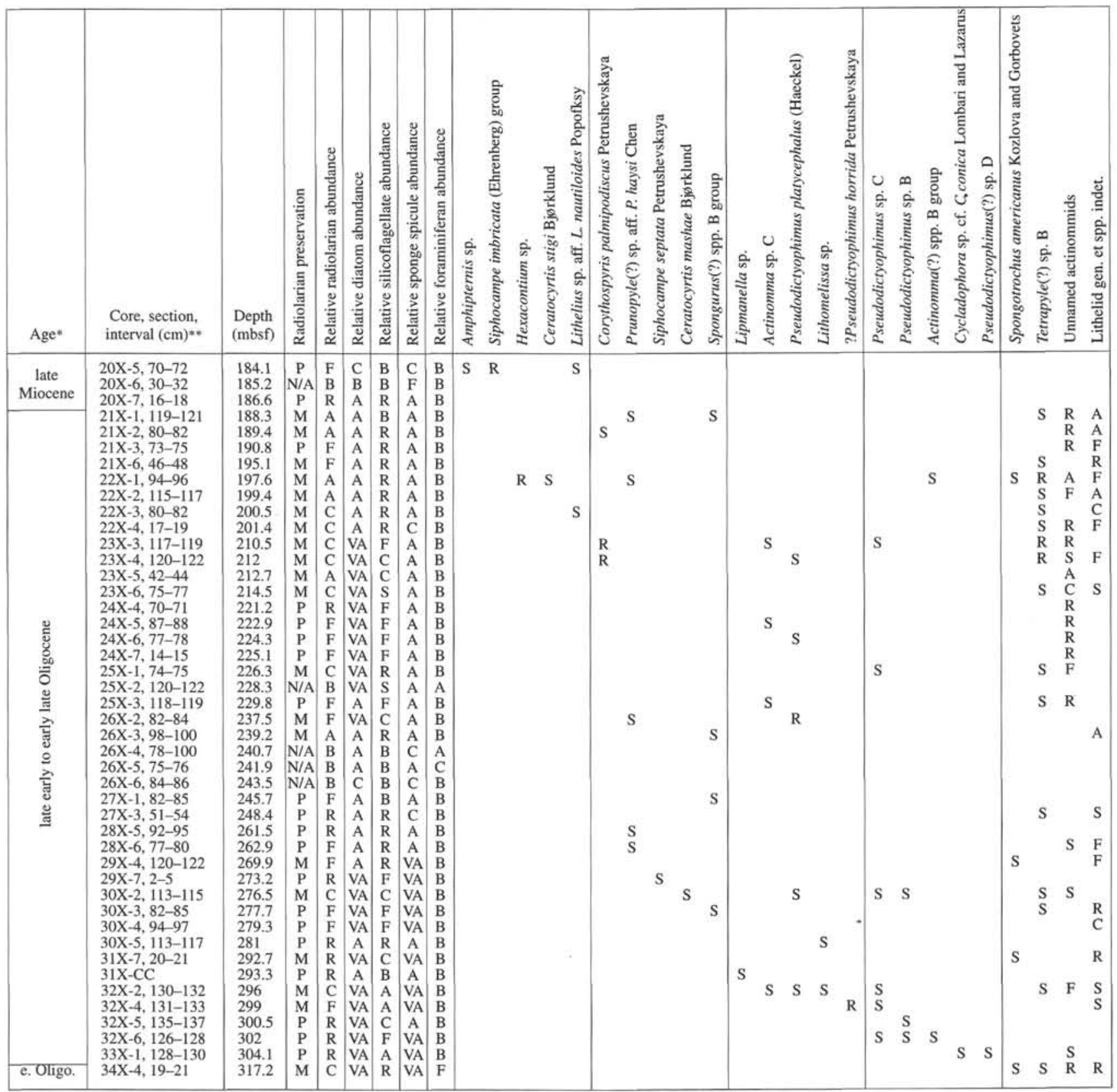

Note: * Age is based on correlation with diatom, silicoflagellate, and palynomorph stratigraphies. * Over 100 samples were analyzed for this site; only those samples containing radiolarians are listed. For symbol explanations, see introduction to the "Systematics" section of text.

distinctive forms from Sites 908 and 913, relative abundance and occurrence charts were constructed (Tables 1,2 ) and the preservation recorded. Definitions of the symbols used in these charts are presented below in the "Systematics" section.

Finally, because so little is known about the Paleogene faunas of the Norwegian-Greenland Sea, direct comparisons were made with several other slide collections of high-latitude Eocene and Oligocene radiolarians. These included collections from Leg 38 sites (K. Bjørklund and the Microfossil Reference Collections at Scripps Institute and ODP Headquarters), Labrador Sea (D. Lazarus), and Antarctica (A. Abelmann and J.-P. Caulet). Additional exchanges of information and photographs were made with I. Popova and R. Goll. The result of these efforts was to expand the known paleogeographic distri- bution of some high-latitude species, both named and unnamed. The distribution information gathered to date is presented on Table 3 and in the taxonomic portion of the text, under "occurrence" for each species.

\section{EOCENE-OLIGOCENE PALEOCEANOGRAPHY OF THE NORWEGIAN-GREENLAND SEA}

Only two ocean drilling legs, DSDP Leg 38 and ODP Leg 104, and a sparse number of shallow cores (e.g., Vema Core 28-43) have recovered Paleogene sediments for scientific study. Thus, the extent of our understanding of the early paleoceanographic evolution of the 
Table 2. Preservation, abundance, and occurrence of radiolarians in Hole 913B.

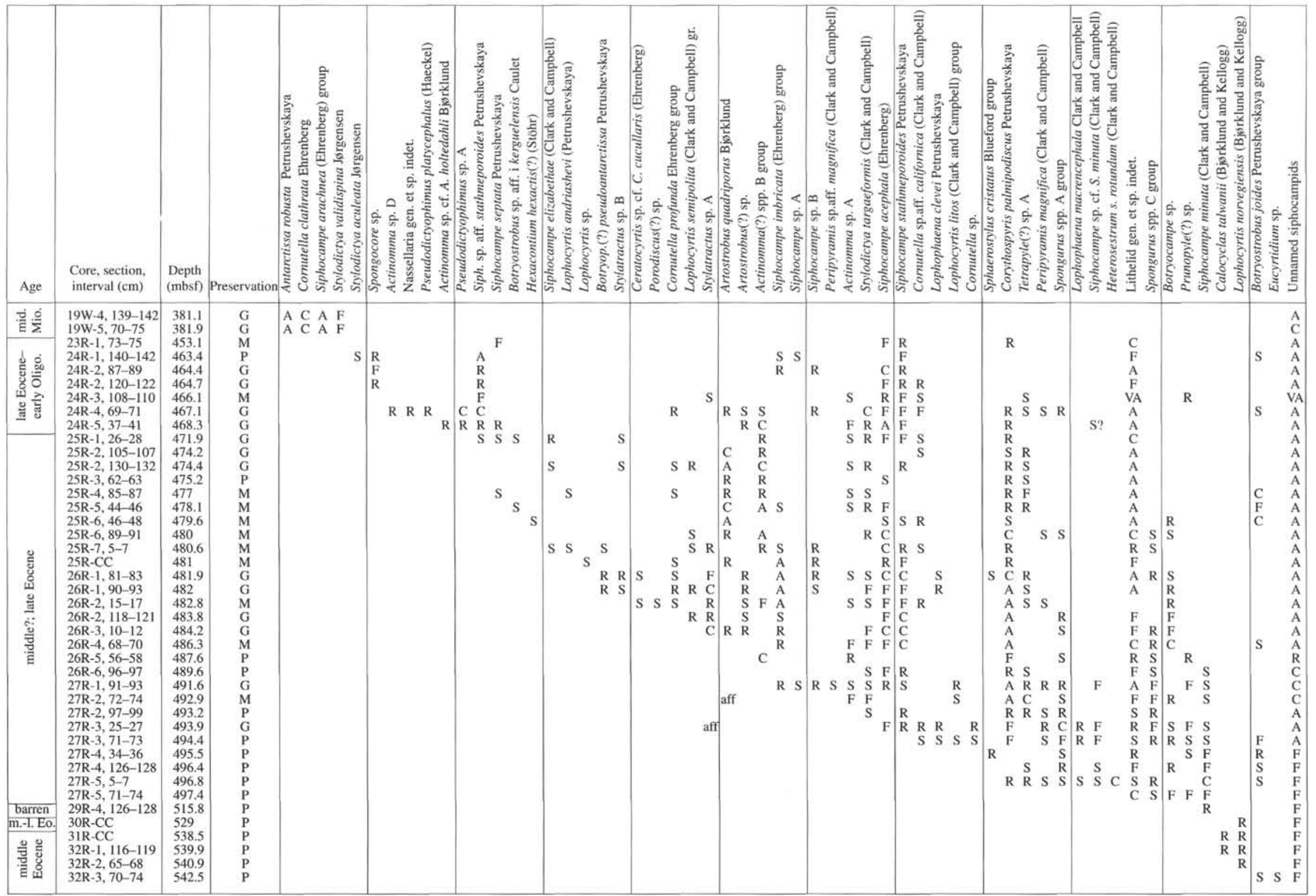

Notes: Ages based in part on suggested age ranges of radiolarian species from within and outside of the Norwegian-Greenland Sea, and on dinoflagellate, diatom, and silicoflagellate stratigraphies (Firth; Scherer and Koç; and Locker, all this volume). See introduction to "Systematics" section in text for explanations of symbols. 


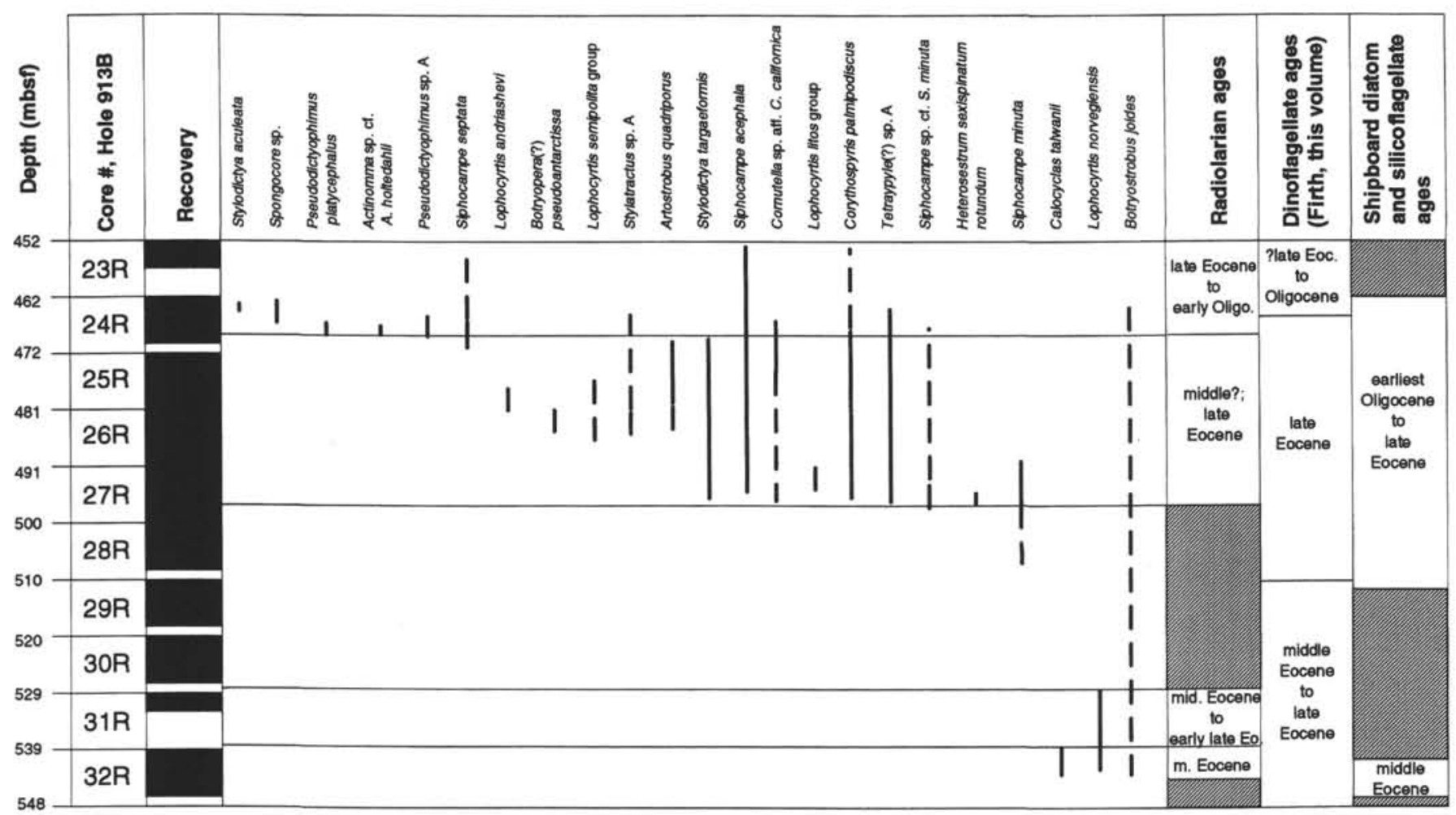

Figure 2. Selected radiolarian ranges in Hole 913B correlated with dinoflagellate (Firth, this volume) and shipboard diatom and silicoflagellate stratigraphies (Myhre, Thiede, Firth, et al., 1995). Magnetostratigraphic record not available for Site 913. Dashed lines = range of sporadic occurrences; solid lines = continuous or nearly continuous occurrences. Cross-hatch pattern $=$ barren intervals or those containing only non-diagnostic species.

Norwegian-Greenland Sea remains limited, but each Paleogene core brings new insights and allows for further comparisons and contrasts with what is known about the early Tertiary climate and tectonic evolution of this area.

After reaching peak warmth during the early Eocene, the earth's climate is thought to have cooled in a stepwise fashion over a 10-m.y. period from the middle Eocene to earliest Oligocene, with the most significant cooling events taking place during the early/middle Eocene and middle/late Eocene transitions and during the earliest Oligocene (Miller et al., 1987; Boersma et al., 1987; Aubry, 1992; Berggren and Prothero, 1992; Prothero, 1994). As currently defined (at $\sim 34.0 \mathrm{Ma}$ ), the Eocene/Oligocene boundary itself was a fairly quiet period geologically and climatically; this was followed by a 1- to 2-m.y. period of faunal and floral changes (Miller et al., 1982; Boersma et al., 1987; Kaminski, 1988; Thomas, 1992; Aubry, 1992; Baldauf 1992).Oxygen and carbon isotope studies of the late Eocene to early Oligocene boundary period support climatic cooling (e.g., Miller et al., 1987; Zachos et al., 1993) and/or changes in oceanic circulation as the causes of these faunal and floral extinctions, and they indicate the possibility for bipolar formation of deep waters in the earliest Oligocene. On the basis of oxygen isotope data, Miller and Tucholke (1983) suggested that northern sources for bottom water began to form near the end of the Eocene and resulted in strong bottom-current erosion and current-controlled sedimentation which persisted throughout the Oligocene to early Miocene. Miller and Fairbanks (1983) corroborated these conclusions with the addition of carbon isotope data. Nonetheless, although it has been well established that continental glaciation of Antarctica began in the earliest Oligocene (and hence also the formation of southern hemisphere cold, deep waters; Barron, Larsen, et al., 1989), the source and influence of such bottom waters in the northern hemisphere is still debated. Wold et al. (1993) suggest that a raised shelf near the Rockall Trough served as a site for cold deep-water formation in the North Atlantic during the early Oligocene.
Seismic evidence for increasing bottom water circulation around the time of the Eocene/Oligocene boundary has been noted in the North Atlantic for over two decades (e.g., Johnson and Schneider, 1969; Ruddiman, 1972). Roberts (1975) distinguished "reflector R4", a subhorizontal sedimentary reflector overlain by sediment drifts. The age of the reflector is thought to be latest Eocene in the Rockall Plateau and Rockall Trough (Roberts, 1975) and the Reykjanes Ridge (Ruddiman, 1972), and earliest Oligocene in the Labrador Sea (Miller et al., 1982). Miller et al. (1982) note that the timing of increased bottom circulation suggested by reflector $\mathrm{R} 4$ provides an explanation for the widespread hiatuses in late Eocene to Oligocene sections, particularly in the North Atlantic (Moore et al., 1978; Keller et al., 1987). Coincident with these hiatuses, Haq et al. (1987) show a short-term fall in eustatic sea level in the earliest Oligocene. Global causes for the increased bottom circulation may therefore be related to increased cooling and southern hemisphere ice formation resulting in increased production of cold bottom waters, as well as lower sea levels. In affirmation of these global patterns, there is increased reworking of Cretaceous to Eocene dinoflagellates around the Eocene/ Oligocene boundary on Leg 151 (see Firth, this volume).

\section{Paleoceanographic Results from Previous Legs}

Leg 38 drilled and spot-cored 16 separate sites in the southern and eastern portions of the Norwegian-Greenland Sea. At least 10 of these sites recovered Oligocene and older sequences (Talwani, Udintsev, et al., 1976). Studies of the microfossils extracted from these sequences have indicated differing degrees of endemism and communication between this sea and the world's oceans. In an overview of the faunas and floras of the northern North Atlantic, Berggren and Schnitker (1983) noted that floral and faunal data show the existence of marine communication between the Norwegian-Greenland Sea and the North Atlantic as early as the early Eocene. They suggest further that the oceanic link may have been across the Iceland-Faeroe 
Table 3. Paleogeographic distribution of selected radiolarian species from the Norwegian-Greenland Sea.

\begin{tabular}{|c|c|c|c|c|c|}
\hline Radiolarian species & Leg 151 sites* $^{*}$ & $\begin{array}{l}\text { Other Norwegian-Greenland Sea } \\
\text { sites }\end{array}$ & $\begin{array}{l}\text { Labrador Sea } \\
\text { (Leg 105) }\end{array}$ & $\begin{array}{c}\text { Antarctica } \\
\text { (Legs 28, 29, 113, 119, 120) }\end{array}$ & $\begin{array}{l}\text { Other occurrences } \\
\text { (incl. land sections) }\end{array}$ \\
\hline $\begin{array}{l}\text { Antarctissa robusta } \\
\text { Petrushevskaya }\end{array}$ & $\begin{array}{l}\text { Hole 913B, 19W (middle } \\
\text { Miocene) }\end{array}$ & Unknown & $\begin{array}{c}\text { Hole } 647 \mathrm{~A}, \text { Core } \\
13 ; \text { common in } \\
\text { early Miocene }\end{array}$ & $\begin{array}{l}\text { late Oligocene? late } \\
\text { Miocene }\end{array}$ & Unknown \\
\hline $\begin{array}{l}\text { Artostrobus quadriporus } \\
\text { Bjørklund }\end{array}$ & Hole $913 B$, Cores 24 to 26 & $\begin{array}{l}\text { Site } 337 \text {, Cores } 9,11 \text {; Site } 339 \text {, } \\
\text { Core } 11,12 \text {; Site } 340 \text {, Cores } 3 \text { to } \\
11\end{array}$ & Unknown & Leg 28 , Hole $280 \mathrm{~A}$, Core 4 & Unknown \\
\hline $\begin{array}{l}\text { Botryostrobus sp. aff. } B \text {. } \\
\text { kerguelensis Caulet }\end{array}$ & Hole 913B, Core 25 & $\begin{array}{l}\text { Closely related form at Site } 338 \text {, } \\
\text { Core } 29 \text { (Hull, pers. obs.) }\end{array}$ & $\begin{array}{l}\text { Hole } 647 \mathrm{~A} \text {, Core } \\
21\end{array}$ & Unknown & Unknown \\
\hline $\begin{array}{l}\text { Botryostrobus joides } \\
\text { Petrushevskaya group }\end{array}$ & Hole $913 \mathrm{~B}$, Cores 24 to 27 & $\begin{array}{l}\text { Site } 338 \text {, Cores } 26-28 ; \text { Site } 340, \\
\text { Core } 11 \text {; Site } 339 \text {, Cores } 8 \text { and } 9\end{array}$ & Unknown & Leg 119, Kerguelen Plateau & $\begin{array}{l}\text { Leg } 12, \text { Site } 112 \text {, Core } \\
11(\mathrm{CC}) \text { and } 5(\mathrm{CC})\end{array}$ \\
\hline $\begin{array}{l}\text { Calocyclas talwanii } \\
\text { Bjørklund and Kellogg }\end{array}$ & Hole 913B, Cores $31 \& 32$ & $\begin{array}{l}\text { Site 338, Cores 27-29; Site 340; } \\
\text { Cores 7-10; Vema Core 28-43 }\end{array}$ & Unknown & Unknown & ?Eocene of California \\
\hline $\begin{array}{l}\text { Ceratocyrtis mashae } \\
\text { Bjørklund }\end{array}$ & Hole $908 \mathrm{~A}$, Core 30 & Site 338 , Cores $11-16$ & Unknown & $\begin{array}{l}\text { Legs } 113,119 \text {, and } 120 ; \\
\text { early Oligo.-middle Mio. }\end{array}$ & Unknown \\
\hline Ceratocyrtis stigi (Bjørklund) & Hole $908 \mathrm{~A}$, Core 22 & Site 338 , Core 8 & Unknown & $\begin{array}{l}\text { Leg } 28,113,119 \text {; early } \\
\text { Oligo.-middle Mio. }\end{array}$ & Unknown \\
\hline $\begin{array}{l}\text { Corythospyris palmipodiscus } \\
\text { (Petrushevskaya) }\end{array}$ & $\begin{array}{l}\text { Hole } 913 \mathrm{~B}, \text { Cores } 24 \text { to } 27 \\
\text { Hole } 908 \mathrm{~A} \text {, Core } 23\end{array}$ & $\begin{array}{l}\text { Sites } 337 \text { (Core 9), } 338 \text { (Cores 19- } \\
\text { 21), } 340 \text { (Core 11) }\end{array}$ & Unknown & Unknown & $\begin{array}{l}\text { middle(?) Eocene } \\
\text { Oceanic Fm., Barbados }\end{array}$ \\
\hline $\begin{array}{l}\text { Heterosestrum sexispinatum } \\
\text { rotundum (Clark and } \\
\text { Campbell) }\end{array}$ & Hole 913 B, Core 27 & Site 338 , Core 28 ; Site 340 , Core 4 & Unknown & Unknown & Eocene of California \\
\hline $\begin{array}{l}\text { Lophocyrtis litos (Clark and } \\
\text { Campbell) group }\end{array}$ & $\begin{array}{l}\text { Hole } 913 \mathrm{~B} \text {, Cores } 26 \text { to } \\
27(-2)\end{array}$ & $\begin{array}{l}\text { Site } 338 \text {, Core } 26 \text {; Site } 339 \text {, Core } \\
12 \text {; Site } 340 \text {, Cores } 9 \text { to } 11\end{array}$ & Unknown & Unknown & Eocene of California \\
\hline $\begin{array}{l}\text { Lophocyrtis norvegiensis } \\
\text { Bjørklund and Kellogg }\end{array}$ & Hole $913 \mathrm{~B}$, Cores 30 to 32 & $\begin{array}{l}\text { Site 338, Cores 26-28; Site 339, } \\
340 \text { (Core 11) }\end{array}$ & Unknown & $\begin{array}{l}\text { Site } 699 ; \text { broader range if } \\
\text { junior synonym of } \\
\text { Lophocytis biaurita }\end{array}$ & Rockall Plateau \\
\hline $\begin{array}{l}\text { Lophocyrtis semipolita } \\
\text { (Clark and Campbell) group }\end{array}$ & Hole $913 \mathrm{~B}$, Cores 26 to 32 & Site 340 , Core 10 & Unknown & Leg 119, Kerguelen Plateau & Eocene of California \\
\hline $\begin{array}{l}\text { Lophophaena macrencephala } \\
\text { Clark and Campbell }\end{array}$ & Hole 913B, Core 27 & $\begin{array}{l}\text { Site } 340, \text { Core 7: Site 338, Core } 28 \\
\text { (Hull, pers. obs.) }\end{array}$ & Unknown & Unknown & $\begin{array}{l}\text { Kreyenhagen Formation } \\
\text { (Eocene) of California }\end{array}$ \\
\hline $\begin{array}{l}\text { Pseudodictyophimus } \\
\text { platycephalus (Haeckel) }\end{array}$ & $\begin{array}{l}\text { Hole } 913 \mathrm{~B} \text {, Core } 24 \text {; Hole } \\
908 \mathrm{~A} \text {, Cores } 26 \text { to } 32 .\end{array}$ & Site 338 , Core 9 & $\begin{array}{l}\text { Hole } 647 \mathrm{~A}, \text { Cores } \\
15 \text { and } 25 \text { (Hull, } \\
\text { person. observ.) }\end{array}$ & $\begin{array}{l}\text { Leg 113, Hole 689B, Core } 8 \\
\text { (Hull, pers. obs.) }\end{array}$ & Unknown \\
\hline $\begin{array}{l}\text { Siphocampe minuta (Clark } \\
\text { and Campbell) }\end{array}$ & Hole $913 B$, Cores 26 to 29 & Site 337 , Core 11 & Unknown & Unknown & Eocene of California \\
\hline $\begin{array}{l}\text { Siphocampe septata } \\
\text { Petrushevskaya }\end{array}$ & $\begin{array}{l}\text { Hole 913B, Cores 23-25; } \\
\text { Hole 908A, Core } 29\end{array}$ & $\begin{array}{l}\text { Site 337, Cores 9-11; Site 338, } \\
\text { Cores 26-29; Site 339, Core 10; } \\
\text { Site } 340\end{array}$ & Unknown & $\begin{array}{l}\text { Hole 766A (Leg 119), early } \\
\text { Oligocene }\end{array}$ & $\begin{array}{l}\text { Leg } 12 \text {, Site } 112 \text {, Core } 11 \\
\text { (CC) }\end{array}$ \\
\hline $\begin{array}{l}\text { Siphocampe stathmeporoides } \\
\text { Petrushevskaya }\end{array}$ & Hole $913 \mathrm{~B}$, Cores 23 to 27 & Site 337 , Core 11 & Unknown & $\begin{array}{l}\text { Leg 29, Sites 275, 278, and } \\
280 \mathrm{~A}\end{array}$ & Leg 14, Site 144, Core 2 \\
\hline $\begin{array}{l}\text { Sphaerostylus cristatus } \\
\text { Blueford group }\end{array}$ & Hole $913 \mathrm{~B}$, Cores 26 to 27 & ?Sites $338,340,339$ & $\begin{array}{l}\text { Hole } 647 \mathrm{~A} \text {, } \\
\text { Oligocene to } \\
\text { early Miocene }\end{array}$ & Unknown & $\begin{array}{l}\text { Eocene of California; } \\
\text { mid.-late Mio., } \\
\text { equatorial Pacific }\end{array}$ \\
\hline Spongocore sp. & $\begin{array}{l}\text { Hole } 913 \text { B, Core } 24 \\
\text { (Sections } 1 \text { \& } 2 \text { only) }\end{array}$ & Unknown & $\begin{array}{l}\text { Hole } 647 \mathrm{~A} \text {, } \\
\text { Oligocene to } \\
\text { early Miocene }\end{array}$ & Oligocene of Leg 29 & $\begin{array}{l}\text { middle to late Miocene of } \\
\text { California Monterey } \\
\text { Formation }\end{array}$ \\
\hline $\begin{array}{l}\text { Spongotrochus americanus } \\
\text { Kozlova and Gorbovets }\end{array}$ & Hole $908 \mathrm{~A}$, Cores 22 to 29 & Unknown & Unknown & Unknown & $\begin{array}{l}\text { late Eocene of western } \\
\text { Siberia }\end{array}$ \\
\hline
\end{tabular}

Notes: *See Tables 1 (Site 908) and 2 (Site 913) for more detailed abundance and occurrence data. Sources: Bjørklund, 1976; Dzinoridze et al., 1978; Petrushevskaya, 1975, 1979; Petrushevskaya and Kozlova, 1972; Benson, 1972; Lazarus and Pallant, 1989; Chen, 1975; Abelmann, 1990; Caulet, 1991; Takemura, 1992; Clark and Campbell, 1942, 1945; Westberg-Smith and Riedel, 1984; Kozlova and Gorbovets, 1966; J.-P. Caulet, R. Goll, and A. Sanfilippo, pers. comms., 1994 \& 1995 ; Hull, pers. obs., 1994 \& 1995.

Ridge, through the North Sea, or via epicontinental seas, such as the shallow sea that existed on the margin of Greenland and Scandinavia in the Late Cretaceous and Paleocene before the initiation of seafloor spreading. The northward spread of warmer North Atlantic waters would have been vital in maintaining the relatively mild climate of Svalbard, which supported a much warmer fauna and flora during at least the early Eocene. Principal lines of evidence for Berggren and Schnitker's conclusions include nannofossils from Sites 338 and 343, which share close affinities with Site 117A (Rockall Plateau) and northwest Germany (Müller, 1976), and planktonic and benthic foraminifers (Saito et al., 1967; Berggren and Schnitker, 1983). Although siliceous assemblages contain a significant level of endemism, they do contain a few markers that can be recognized outside the Norwegian-Greenland Sea. The exception was noted by Bjørklund (1976), who stated that Eocene and Oligocene radiolarians from Leg 38 were more similar to those of Siberia than those of the North Atlantic. As a possible explanation, Berggren and Schnitker (1983) proposed that the Greenland-Scotland Ridge may have been shallow enough to have acted as a filter to radiolarians (which are most abundant in the oceans today at depths between 50 and 200 meters below sea level [mbsl]; Petrushevskaya, 1971).

ODP Leg 104 recovered Paleogene rocks at Sites 642 and 643, but interpretations of both sections are complicated by difficulties in biostratigraphic resolution (Goll, 1989; Eldholm, Thiede, Taylor, et al., 1987; Thiede et al., 1989). Eocene flora and fauna recovered at Site 642 entered the Norwegian-Greenland Sea with the first marine transgressions that filled the newly opened basins in the central portion of the sea. Thiede et al. (1989) suggest that this marine transgression may have come from either the Arctic Ocean or across the Greenland-Scotland Ridge during its early history. The similarities between hiatuses in the Norwegian-Greenland Sea (Goll, 1989) and the global record (Keller et al., 1987) provide support for the latter, but nonetheless there is little evidence against an Arctic incursion, inasmuch as little is known about the Paleogene Arctic. Kaminski (1988) stated that similarities between agglutinated foraminifers in the North Sea and on the Vøring Plateau during the early Eocene make a bathyal connection between these areas a strong possibility as well. 


\section{Implications of Leg 151 Radiolarians}

Radiolarians recovered from Sites 908 and 913 provide a valuable opportunity to study siliceous microfossils at an interesting time both in the evolution of the Norwegian-Greenland Sea and in the evolution of global climate. Endemism, preservation, and less-than-optimal environments hamper efforts, but, nonetheless, several observations can be made. In particular, Site 913 faunas illustrate an increase in productivity, and probably upwelling, during the late Eocene and earliest Oligocene (Myhre, Thiede, Firth, et al., 1995). Intervals of true "siliceous ooze" were recovered at this site, and $\mathrm{C} / \mathrm{N}$ ratios indicate that the organic carbon is marine in origin. The timing of this increased biogenic silica productivity corresponds approximately with the increase in biogenic silica deposition discovered at previously drilled Norwegian-Greenland Sea sites, in the Labrador Sea and in the North Atlantic (Riech and von Rad, 1979; Ehrmann and Thiede, 1985; Bohrmann and Stein, 1989).

The lack of abundance and good preservation of radiolarians at Site 908 is probably the result of the depositional environment; diatoms and silicoflagellate floras indicate deposition on a shelf with water depths of $\sim 150 \mathrm{~m}$ (R. Scherer and S. Locker, pers. comms., 1994). Such an environment is less than ideal for radiolarians, which usually prefer a more open ocean setting. High sedimentation rates at the site (Myhre, Thiede, Firth, et al., 1995) also have diluted what few radiolarians did thrive in this environment. Calcareous microfossils are preserved in a few intervals: Sections 151-908A-25X-2, 26X-4, and $26 \mathrm{X}-5$ contain abundant benthic foraminifers, and calcareous nannofossils were extracted from an interval in Core 151-908A-31X.

Silicoflagellates from Site 908 show affinities with both western Siberia (Barents shelf region) and with the North Atlantic (S. Locker, pers. comm., 1994). Although at least one radiolarian species present at Site 908 is known from western Siberia, most of the fauna is dominated by unnamed and unknown species of pseudodictyomitrids, actinommids, and lithelids. The few formalized species are principally known only from the Norwegian-Greenland Sea, with the exception of four species that are also present in Oligocene sequences drilled off of Antarctica (Ceratocyrtis mashae, C. stigi, Pseudodictyophimus platycephalus, and Siphocampe septata; see Tables 1,3).

Site 913 radiolarians from the Greenland Basin support Bjørklund's (1976) assertion that the Paleogene Norwegian-Greenland Sea faunas have little in common with North Atlantic faunas, including those from the Rockall Plateau just south of the Greenland-Scotland Ridge. However, Norwegian-Greenland Sea faunas should not be considered entirely endemic and isolated. With the continuation of deep-sea drilling at high latitudes, it is now possible to compare Eocene Norwegian-Greenland Sea radiolarians with other high-latitude sections globally. The resulting picture is that of a largely endemic fauna that has its strongest affinities with western Siberia and the eastern Pacific basin (California), less significant but very real ties with Antarctica, and its weakest affinities with the tropical to temperate Atlantic (Table 3). Dzinoridze et al. (1978) have also noted similarities of the Norwegian-Greenland faunas with other parts of Eurasia (e.g., Ukraine, Kazakhstan). Affinities with the Labrador Sea cannot be ascertained because these faunas overlap only in the poorly biostratigraphically constrained Oligocene; no radiolarian-bearing Eocene sediments were recovered from the Labrador Sea on ODP Leg 105 (Lazarus and Pallant, 1989). Similarly, any "Arctic" affinity of these faunas cannot be determined inasmuch as no radiolarianbearing Paleogene sediments have been recovered from the Arctic basin, although biosilica-rich floras have been cored (Barron, 1985; Dell'Agnese and Clark, 1994). The Norwegian-Greenland Sea-Siberia-eastern Pacific connection does suggest that if Eocene radiolarians found the Arctic region to be habitable, there should be close affinities with this region as well.

Another "phenomena" associated with Site 913 radiolarians deserves brief mention. At the top of Sections 151-913B-24R-1 and
$24 \mathrm{R}-2$, up to $60 \%$ or more of the radiolarian assemblages, which are low in diversity and dominated by artostrobiids, lithelids, and large actinommids, exhibit some mechanical breakage, mostly in the loss of artostrobiid cephalises at the stricture between the cephalis and thorax. This breakage is also visible on smear slides of unprocessed sediment, and thus is not a result of laboratory methods. These same sections contain: (1) rare Cretaceous? reworked radiolarians (e.g., species of Dictyomitra) and a larger number of reworked Late Cretaceous to Eocene dinoflagellates (Firth, this volume); (2) slightly coarser grain sizes than the intervals above and below; and (3) much reduced abundance and diversity of diatom floras (Scherer, this volume). The predominance of radiolarians over diatoms is not at all common in the high latitudes, which typically favor diatom blooms over radiolarian blooms. Although there have been no quantitative analyses published, it is generally thought that robust artostrobiids tend to be "upwelling enhanced" in high latitudes (Casey, 1993; K. Bjørklund, pers. comm., 1994). Thus, the artostrobiid bloom may be a good upwelling indicator, but either the upwelling did not produce a simultaneous diatom bloom or a large percentage of the diatoms were removed by other processes. In view of the cumulative evidence, it is likely that the diatoms were winnowed away by increased bottom circulation; there is only minor observable evidence in the faunas that dissolution has played a role as well.

The approximate age of the sequence in this interval according to the microfauna and microflora is latest Eocene to earliest Oligocene (i.e., the approximate position of the Eocene/Oligocene boundary) or slightly younger. Therefore, the "boundary" in this succession rests within a reworked interval that may or may not include a brief hiatus; although precise correlations are difficult, the age range of this interval coincides in general with Keller et al.'s (1987) global hiatus "PHc" and the age of reflector R4, dated as latest Eocene on the Iceland Plateau (Ruddiman, 1972). Reflector R4 is dated as early Oligocene in the Labrador Sea, where it appears to define the lower limit (rather than the upper limit as in the Norwegian-Greenland Sea) of sediments rich in biogenic silica (Srivastava, Arthur, Clement, et al., 1987). Thus, even though the extent of bottom water communication with the North Atlantic, Arctic and adjacent regions is uncertain (Thiede et al., 1989), evidence from Site 913 argues for increased bottom-water circulation around the Eocene/Oligocene transition, similar to the sedimentologic records of the North Atlantic and elsewhere in the Norwegian-Greenland Sea.

\section{EOCENE-OLIGOCENE RADIOLARIAN BIOSTRATIGRAPHY}

As currently defined by stratigraphic convention, the Eocene/Oligocene boundary is at the 19-m mark in the Massignano section of the Italian Apennines. It is recognized by the last appearance of the planktonic foraminifer genus Hantkenina, which occurs in the upper third of Chron C13R at $\sim 34.0 \mathrm{Ma}$ (Premoli-Silva et al., 1988; Berggren and Prothero, 1992). One of four candidates considered for the stratotype, the Massignano section was selected because of its rich calcareous microfossil assemblages (planktonic foraminifers and calcareous nannofossils), magnetic record, and datable ash layers (Premoli Silva et al., 1988; Berggren and Prothero, 1992). Despite the vote of approval, however, many workers remain unsatisfied with the selection (Brinkhuis, 1992; McGowran et al., 1992), inasmuch as most major global changes and extinctions of this time period occur in what is now the early Oligocene, about $1 \mathrm{~m} . \mathrm{y}$. after the extinction of Hantkenina (Prothero, 1994).

Recognition of the Eocene/Oligocene boundary in the Norwegian-Greenland Sea is met with difficulty from the outset on three counts: (1) the boundary stratotype is selected from the TethyanMediterranean region and, by their very nature, the low-latitude markers are unlikely to be found in high-latitude regions; (2) high-lat- 
itude stratigraphies developed by interpolating from low-latitude zonations to high-latitude zonations may not have incorporated the relatively new definition of the Eocene/Oligocene boundary (noted above) into their schemes; and (3) the high level of endemism in the Norwegian-Greenland Sea makes correlation via geographic stepping stones very difficult, even from the temperate North Atlantic. As noted by Riedel and Sanfilippo (1986), because the stratotype for the Eocene/Oligocene boundary does not contain radiolarians, this group cannot be used independently to recognize the boundary in other successions. Radiolarian first and last occurrences can, however, be compared and contrasted to calcareous microfossil events defined at the boundary. Riedel and Sanfilippo (1986) conducted this type of radiolarian study for the Bath Cliffs section of Barbados, one of the original four Eocene-Oligocene stratotype candidates. They recorded five extinction events $\sim 0.5 \mathrm{~m} . \mathrm{y}$. before the boundary and three last occurrences and an evolutionary transition $\sim 0.5 \mathrm{~m}$.y. after the last appearance of Hantkenina; no events coincided directly.

Numerous radiolarian events at or near the Eocene/Oligocene boundary have been identified in the subantarctic. Caulet (1991) noted six LCOs (last common occurrence) and six FCOs (first common occurrence) at or just above the Eocene/Oligocene boundary at Site 738 on the southern tip of the Kerguelen Plateau. Correlations of his radiolarian events to the time scale were made via calcareous nannofossils and planktonic foraminifers. Among the Paleogene species identified by Caulet (1991) is the Calocyclas semipolita (Clark and Campbell) group, which has its last occurrence in the early Oligocene. C. semipolita has been identified in this study at Site 913 in the Norwegian-Greenland Sea (=Lophocyrtis semipolita), although specimens are rare and tend to be broken. Nonetheless, the species may provide a link between the northern and southern polar regions. Takemura (1992) also studied radiolarian events across the Eocene/ Oligocene boundary in the Southern Ocean and noted several first occurrence events in the early Oligocene of Hole 748B, marking the top of his Eucyrtidium spinosum Zone, which straddles the boundary.

\section{Eocene-Oligocene Radiolarian Biostratigraphy of the Norwegian-Greenland Sea}

Primary Paleogene radiolarian studies for the Norwegian-Greenland Sea include Bjørklund (1976), Dzinoridze et al. (1978), Petrushevskaya (1979), and Bjørklund and Kellogg (1972). The former three are based on material collected on Leg 38. The latter reference describes new Eocene species from Vema Core 28-43 collected from the Norwegian Sea. In addition, there are a very few group-specific publications of Norwegian-Greenland Sea radiolarians that deal strictly with taxonomy (e.g., Goll, 1978).

Discontinuous sequences recovered by spot coring at different sites on Leg 38 were arranged in stratigraphic context with respect to one another without definitive age control. The result, in the case of the radiolarians, is a set of stratigraphically ordered radiolarian zones (Bjørklund, 1976; Dzinoridze et al., 1978) with weakly defined (or undefined) tops and bases that were calibrated to the geologic time scale through other microfossil stratigraphies. Some of these stratigraphies (e.g., diatoms, in Fenner, 1985) have since been revised; no revisions of the radiolarian zones have been published.

As an example of the complexities of these zonations, the lowermost biostratigraphic unit of the Oligocene, and hence potential recognition of the Eocene/Oligocene boundary, is represented by the base of the Lithomitra sp. A Zone in the Bjørklund (1976) radiolarian zonation. The creation of this zone at that time was based on the recovery of an assemblage recovered from a single site (Site 339), and its precise stratigraphic utility or position undetermined, which Bjørklund (1976) recognized. This zone has an undefined base and top, and its stratigraphic usefulness on Leg 151 has not been realized. Part of the complication is because the nominal species for which the zone was named is not defined in Bjørklund's (1976) study. "Lith- omitra spp." are illustrated in the report (plate 23, figs. 1-6), but no specimen is distinguished as Lithomitra sp. A. The illustrated group does include a morphotype assigned herein to Siphocampe acephala, but this species has a long stratigraphic range extending from at least the middle Eocene to the early Miocene, and thus does not serve as a useful biostratigraphic marker. Also, there is some question regarding the precise stratigraphic position of the two "late Eocene" radiolarian zones underlying the Lithomitra sp. A Zone in the Bjørklund zonation. Studies by Fenner (1985), Ciesielski and Amigo (unpubl. data; pers. comm., 1995), and herein suggest that the original calibrations between Eocene radiolarians and other microfossil groups on Leg 38 need refinement (see discussion of Site 913 below).

The Dzinoridze et al. (1978) zonation, based on the same Leg 38 material, consists of a greater number of zones utilizing a larger number of species than Bjørklund (1976). Limited by the same difficulties caused by spot-coring techniques, Dzinoridze et al. (1978) derived their calibrations by comparing their diatom and radiolarian assemblages with similar assemblages in sections throughout Eurasia (West Siberia, Kazakhstan, Ukraine, etc.) and elsewhere. There are difficulties in using Dzinoridze et al.'s radiolarian taxonomy, inasmuch as western and Russian workers have often emphasized different groups and used different criteria for distinguishing between species and genera. Dzinoridze et al. also introduced a number of new morphotypes (distinguished as "var." or "forma Cr," etc.) without any written explanations for the distinctions made. Consequently, it is difficult to compare Bjørklund's and Dzinoridze et al.'s zonations directly. In this study, references to their zones are used where possible in describing the Leg 151 faunas. Clearly, Paleogene biostratigraphy of the Norwegian-Greenland Sea is in need of long, continuously cored Eocene and Oligocene sections in order to produce more accurate biostratigraphic zonations.

\section{EOCENE AND OLIGOCENE RADIOLARIANS AT LEG 151 SITES}

\section{Site 908}

Radiolarians from Site 908 on the Hovgård Ridge are very rare and poorly to moderately preserved from Core 151-908A-20X to $34 \mathrm{X}$ (Table 1). The most abundant forms are unnamed genera and species of actinommids and lithelids. The latter is a group of radiolarians that are not well understood and thus far have no biostratigraphic utility, although efforts are being made to study this group in greater detail (I. Popova and D. Lazarus, pers. comms., 1994). Only 22 other taxa have been identified at this site, and most of these are single occurrences of specimens. There are a few species present that have known occurrences outside of the Norwegian-Greenland Sea, including Siphocampe imbricata, S. septata, Corythospyris palmipodiscus, Ceratocyrtis stigi, C. mashae, Pseudodictyophimus platycephalus, and Spongotrochus americanus (see Table 3).

Core 151-908A-20X is late Miocene, based on diatoms, palynomorphs, and ebridians. Radiolarians present include $S$. imbricata, Amphipternis sp., and Lithelius sp. aff. L. nautiloides. An unconformity is recognized at the base of Core 151-908A-20X at 185 mbsf. Below this, the section is late early Oligocene to early late Oligocene from Core 151-908A-21X to $33 \mathrm{X}$ based on palynomorphs, radiolarians, diatoms, and silicoflagellates. Core $34 \mathrm{X}$ and lower may be restricted to the early Oligocene based on diatoms (Scherer and Koç, this volume). Benthic foraminifers are present in the lower succession, but provide limited age control (Myhre, Thiede, Firth, et al., 1995).

The Oligocene radiolarian fauna ranges from Bjørklund's (1976) "Phorticium sp. A Zone" (Phorticium sp. A = Tetrapyle(?) sp. B herein) to his Velicucullus oddgurneri Zone. Because the markers used to define these zones are mostly absent, the assignment can only be based on the presence of "Phorticium sp. A," which is present 
from Sample 908A-21X-1, 119-121 cm to Section 151-908A-34X4. The Phorticium sp. A Zone was defined in Site 338 material from Cores 338-21 to 24-3, then calibrated to the diatoms zones Pseudodimerogramma filiformis and Sceptroneis pupa of Schrader and Fenner (1976). Originally assigned to the middle Oligocene to early late Oligocene, Fenner (1985) recalibrated these two diatom zones to the late early to early late Oligocene. Diatom data from Site 908 may extend the $S$. pupa Zone farther down into the early Oligocene (Scherer and Koç, this volume), but the age of the lowermost portion of the hole is constrained by a single nannofossil horizon, Sample 151-908A-31X-1, $8 \mathrm{~cm}$, dated as lower NP 23 ( $32 \mathrm{Ma}$; J. Backman, pers. comm., 1995).

The Dzinoridze et al. (1978) radiolarian zonation includes two formal and two unnamed units for the Oligocene. Although a number of radiolarian species are listed for the Oligocene units (including unnamed ones), none of these species have been identified at Site 908 , and thus the Dzinoridze et al. radiolarian zonation cannot be applied directly to this material. This is probably due in part to the northerly location of Site 908 as well as the inferred neritic environment and poor preservation of the material. Fenner (1985, fig. 4) correlated part of Dzinoridze et al.'s "Unit with Gonothecium decoratum-Coscinodiscus vigilans" and all of their "Unit with Pseudotriceratium radiosoreticulatum" to Schrader and Fenner's S. pupa and P. filiformis Zones, suggesting that an unnamed radiolarian unit and at least part of "Unit with Pseudodictyophimus sp." should be correlative with the Site 908 material.

\section{Site 913}

Site 913 radiolarian recovery includes a middle Miocene assemblage from Core 151-913B-19W, and middle Eocene to earliest Oligocene assemblages from Cores 151-913B-23R to 32R. Preservation of the faunas ranges from moderate to good in Cores 151-913B-23R and 24R; the fauna shows significant mechanical abrasion but little chemical dissolution. Good preservation continues downsection to the top of Core 151-913B-27R (Section 2); the remainder of Core $27 \mathrm{R}$ contains poorly preserved radiolarians, and Core $28 \mathrm{R}$ and the top of Core 29R are essentially barren of radiolarians. Sporadic occurrences of radiolarians are present from Sections 151-913B-29R-4 to $32 \mathrm{R}-3$, but these specimens are rare, partially clay infilled and recrystallized. Diversity of the assemblage is lowest at the top of the biosiliceous succession in Cores 913B-23R and 24R (top) and in the lowermost part of the succession. While the latter is due to poor preservation, the upper low-diversity interval is attributed to environmental factors (see discussion above). Diversity is highest from Sections 151-913B-24R-3 to 27R-2.

The composition of the radiolarian fauna at Site 913 has several species in common with the Paleogene Norwegian-Greenland Sea material drilled on Leg 38, and yet a number of easily identifiable forms present in the Leg 38 material are missing at Site 913, suggesting endemism even within the Norwegian-Greenland Sea. This is not unlike the Neogene situation, where zonations established for the Norwegian margin (Goll and Bjørklund, 1989), cannot be fully applied to the Iceland Plateau (Myhre, Thiede, Firth, et al., 1995). The causes of this endemism in the Neogene are likely due to paleoceanographic influences, such as periodic influxes of warmer North Atlantic water on the eastern side of the ocean basin, which create different environmental conditions and thus recognizably different faunas within the region (Goll and Bjørklund, 1989). It is a little more surprising, however, that such endemism might exist within the smaller, narrower, and younger ocean basin of the Paleogene Norwegian-Greenland Sea.

Fifty-six species-level taxa have been identified and described for Site 913 herein (Table 1). The most abundant groups present at Site 913 include the artostrobiids (genus Siphocampe), whose full range in morphology on the Greenland margin needs detailed study. Be- cause of their diversity, these radiolarians may ultimately provide better biostratigraphic constraints for the Eocene and early Oligocene. Unnamed genera and species of lithelids are rare to very abundant above the base of Core 151-913B-27R. Spumellarians in general are far less common than nassellarians; the only species or groups reaching "common" (11-20 specimens per slide) or "abundant" levels among the spumellarians (20-50 specimens/slide) are the Actinomma(?) spp. B group, Stylatractus sp. A, Stylodictya targaeformis (Clark and Campbell) and Heterosestrum sexispinatum rotundum (Clark and Campbell). Among the more prominent nassellarians (in addition to artostrobiids) are several species of Lophocyrtis, which are mostly broken in this material, but nonetheless show morphologic variation upsection which may prove to have biostratigraphic utility in better preserved material. Other common to abundant nassellarians are Artostrobus quadriporus, Corythospyris palmipodiscus, Tetrapyle(?) sp. A, Botryocampe sp., and Botrystrobus joides. Some species, such as $B$. joides, appear in multiple short but stratigraphically separated intervals, while others, such as A. quadriporus and Siphocampe imbricata become more abundant in the cores for intervals of 5-7 m, then appear only sporadically in the remainder of the section (Table 1). Species-specific environmental reasons for such short-term influxes and floods are unknown at this time.

The following observations about the relationships between the Bjørklund (1976) and Dzinoridze et al. (1978) biostratigraphic zonations and radiolarians at Site 913 can be made:

1. The lowermost Oligocene zone of Bjørklund (1976), Lithomitra sp. A Zone, has an undefined base and its relationship to the Eocene/Oligocene boundary is unknown. This zone cannot be recognized at Site 913 .

2. The "late Eocene" Calocyclas talwanii and Lophocorys norvegiensis Zones of Bjørklund (1976) occur in the lowermost part of Site 913, Sections 151-913B-30R-CC to 32R-2. Bjørklund and Kellogg (1972) broadly defined the L. norvegiensis zone in Vema Core $28-43$ as being "...delimited by the range of Lophocorys norvegiensis....Calocyclas talwanii and Stylodictya variabilis are both found throughout the entire section studied..." (p. 393). However, as defined by Bjørklund in 1976 (p. 1104) from Leg 38 material, the top of the Calocyclas talwanii Zone is recognized by the last occurrences of $C$. talwanii and Phacodiscus testatus coincident with the first occurrence of $L$. norvegiensis. Data presented for Site 338 (Bjørklund, 1976 , tables 8 and 23) indicates an overlap in the occurrences of these species, not a clear coincidence of first and last occurrences. Thus, the distinction between the two zones needs clarification, but they can be recognized. The uppermost occurrence of $L$. norvegiensis is unknown at Site 338 due to poor preservation and an overlying unconformity; similarly, its uppermost occurrence is lost due to poor preservation at Site 913.

The C. talwanii and L. norvegiensis Zones were originally recognized at Sites 338 (Cores 338-25 to 20) and 341, and calibrated to the late Eocene by Bjørklund (1976) on the basis of silicoflagellates and Schrader and Fenner's (1976) diatom study. Fenner (1985) revised the diatom biostratigraphy, and re-calibrated the same diatom zones to the middle Eocene. Further, she distinguished a hiatus between the middle Eocene and early Oligocene at Site 338. If the diatom recalibrations are followed, C. talwanii and L. norvegiensis Zones from Site 338 should be reassigned to the middle Eocene. However, inasmuch as the uppermost range of $L$. norvegiensis has not been determined either at Site 338 or 913 , the L. norvegiensis Zone could possibly range into the early late Eocene. Dinoflagellate correlations in this study do suggest that at Site 913, these two zones (or at least the $L$. norvegiensis Zone) extend into the early late Eocene (Firth, this volume). 
3. Dzinoridze et al. (1978) identified five radiolarian "units" in the Leg 38 material which they assigned to the middle-late Eocene, and two to the early Oligocene (Stratum I-VII). Because of differences in taxonomic concepts, species ranges and the absence of many marker species in Site 913, correlation to their zonation is very limited. In general, it appears that Cores 151-913B-31R (CC) and 32R are assignable to their Stratum I, "radiolarian unit with Tripodiscium(?) tumulosa" based on the presence of C. talwanii. Core 151-913B-30R with L. norvegiensis in the absence of $C$. talwanii is assignable to either Stratum II or III; preservation in this core is too poor to refine the stratigraphy any further. Core 151-913B-29R to Section 151913B-27R-4 are unassignable to any of the Dzinoridze et al. stratums due to poor preservation and lack of corresponding species. However, the assemblage in Section 151-913B-27R3 to at least the base of Core 151-913B-26R (and probably higher) is assignable to Stratum V, "radiolarian unit with Theocyrtis litos ' $\mathrm{Cr}$ "' based on the co-occurrence of Theocyrtis litos "Cr" (=Theocyrtis litos group herein) and Stylodictya targaeformis. Stratum V was identified by Dzinoridze et al. (1978) from Site 339, Cores 10 to 12. Finally, Dzinoridze et al.'s Stratum VI is unnamed and unrecognized based on radiolarians; Stratum VII cannot be recognized based on the species listed.

Constraints on the ages of Cores 151-913B-23R to 27R, above the $C$. talwanii and $L$. norvegiensis Zones, are difficult to achieve based on radiolarians alone. Correlations with known occurrences of individual species in other regions (e.g., as demonstrated by Dzinoridze et al., 1978) are helpful to a small extent, but still result in very broad age ranges. Local comparisons between Site 913 and the Leg 38 sites indicate the following. Site 338 contains a number of species similar to 913 , but these tend to be either very long-ranging forms or those species restricted to the lowermost part of 913 (Cores 151-913B-30R to $32 \mathrm{R}$, the $L$. norvegiensis and $C$. talwanii Zones). Above Section 151-913B-27R-4, Site 913 does have several species in common with Site 339, including Stylodictya aculeata, Artostrobus quadriporus, Cornutella sp. aff. C. californica, Lophocyrtis andriashevi, Peripyramis sp. aff. P. magnifica, and Siphocampe minuta. Based on unpublished detailed diatom and silicoflagellate stratigraphy, P. Ciesielski and A. Amigo (pers. comms., 1995) have determined that faunas from Site 339 lie stratigraphically within the unconformity at Site 338 ; i.e., in the latest middle Eocene or late Eocene to earliest Oligocene. If correct, Cores 151-913B-27 and younger at Site 913 may represent an interval of approximately the same age.

In summary, the above accumulated data suggests the following: (1) the lowermost assemblages at Site 913 (Cores 151-913B-31R and lower with C. talwanii) are middle Eocene; (2) Core 151-913B-30R (uppermost occurrences of $L$. norvegiensis) is middle Eocene to early late Eocene; (3) assemblages in Sections 151-913B-27R-5 to 151913B-24R-5 are similar to Site 339 and may represent part of the Site 338 unzoned interval indicated by Fenner (1985); herein this interval is assigned to the middle? late Eocene; and (4) the presence of species better known from Oligocene sections in Section 151-913B-24R-5 and higher (e.g., Pseudodictyomitra platycephalus) indicates a possible range for this interval of late Eocene to earliest Oligocene, although the data is poorly constrained.

Calibration with dinoflagellates recovered in Cores 151-913B$20 \mathrm{R}$ to $36 \mathrm{R}$ provides the following stratigraphic interpretation (Firth, this volume; Fig. 2): Cores 151-913B-34R to $36 \mathrm{R}$ are assigned to the middle Eocene; Cores 913B-33R to $29 \mathrm{R}$ are middle to late Eocene; Core 913B-28R to Section 913B-24R-2 is late Eocene; Sections 913B-24R-1 to -20R-3 are approximately at the Eocene/Oligocene boundary (late? Eocene-early Oligocene); and Section 913B-20R-2 and younger is definite Oligocene. This is in close agreement with the radiolarian data, although the dinoflagellate Eocene/Oligocene boundary is placed slightly higher. Firth (pers. comm., 1995) has not- ed that the dinoflagellate species used to mark the top of the Priabonian in high latitudes probably extend above the last occurrence of Hantkenina, Tethyan marker for the Eocene/Oligocene boundary at its stratotype. If true, then the "true" Eocene/Oligocene boundary may be slightly lower than indicated by the dinoflagellate data.

\section{SYSTEMATICS}

Taxonomic notes have been compiled for species identified at Sites 908 and 913. Brief descriptions are included for those simply named "sp. A," "spp. group," etc. Species with formalized names are also discussed where controversy over the species concept exists. Leg 151 radiolarian faunas are dominated by artostrobiids (predominantly Siphocampe), lithelids, spongurids (and other spongy radiolarians), and actinommids. Most members of these groups are unnamed species, forms whose morphologic construction is poorly understood (e.g., lithelids), and species generally not regarded as useful for biostratigraphy. However, among these more common forms are occurrences of less abundant but distinctive species, which may prove to be valuable stratigraphically. Prominent among these species are members of the genera Pseudodictyophimus and Lophocyrtis.

All occurrence and abundance information is presented on Tables 1 (Hole 908A) and 2 (Hole 913B). Abundances are recorded per slide as follows: $\mathrm{S}=$ single, 1 specimen; $R=$ rare, $2-4$ specimens; $F=$ few, $5-10$ specimens; $C=$ common, 11-20 specimens; $\mathrm{A}=$ abundant, $20-50$ specimens, and $\mathrm{VA}=$ very abundant, $>50$ specimens. Preservation is recorded as $\mathrm{P}=$ poor, $\mathrm{M}=$ moderate, and $\mathrm{G}=$ good; poor preservation indicates that specimens are corroded, clay-filled, and/or broken, moderate preservation indicates that specimens are only slightly corroded and broken, and good preservation refers to samples with specimens that are largely unbroken and have no indications of dissolution. Occurrences other than Leg 151 sites are listed below or on Table 3. Synonymies are not necessarily complete, but include the most significant literature references to known species.

\section{SPUMELLARIA}

Actinomma sp. cf. A. holtedahli Bjørklund (Plate 1, Figs. 1, 2)

Remarks: Actinomma holtedahli Bjørklund (1976, p. 1121, pl. 20, figs. 8, 9) is neither described nor illustrated as having any external spines and has a medullary shell with spongy meshwork. The form illustrated herein has at least one thin cylindrical spine extending beyond the outermost cortical shell, one sturdy triradiate spine extending from the surface of the test (visible at different levels of focus) and a latticed medullary shell. This is more similar to a form described as A. sp. cf. A. holtedahli by Abelmann (1990, p. 690, pl. 1, figs. $4 a, b$ ) from the Oligocene of Antarctica, and may be ancestral to $A$. holtedahli Bjørklund in the Norwegian-Greenland Sea.

Occurrence: Rare in Section 151-913B-24R-5.

\section{Actinomma sp. A \\ (Plate 1, Fig. 6)}

Remarks: Actinomma sp. A is a relatively small species characterized by a spherical cortical shell and at least one medullary shell. The medullary shell is connected to the cortical shell by multiple, thin, cylindrical beams. The cortical shell itself is relatively thick, with six to eight circular to subcircular pores across its diameter. Numerous primary and secondary thin, cylindrical spines extend from the cortical shell; longest spines up to three-fourths the diameter of the shell.

Occurrence: Very rare to few in Sections 151-913B-27R-2 to 24R-4.

Actinomma(?) spp. B group

(Plate 1, Figs. 3, 4, 9, 12)

Remarks: These specimens are questionably assigned to Actinomma because of the loosely arranged latticework of the cortical shell in some specimens, and of the medullary shell of all specimens. Pores of the cortical shell usually circular to subcircular, irregularly arranged, and variably sized. Up to eleven primary or secondary spines visible on these specimens; spines extremely thin, cylindrical, straight or gently curved. Longest well-preserved spines are longer than the diameter of the cortical shell.

Specimens from Site 908 are slightly better preserved than those at 913B and generally have larger pores and fewer spines.

Occurrence: Rare to common in Sections 151-913B-26R-5 to 24R-4; rare in Sections 151-908A-22X-2 and 32X-6. 
Actinomma sp. C

(Plate 1, Fig. 5)

Remarks: This form is uniquely recognizable by its rectangular (nearly square) outer medullary shell and polygonal inner medullary (=primary) shell. It is rare in sediments at Site 908, but has been seen in early Oligocene assemblages from the Kerguelen Plateau (Leg 119; J.-P. Caulet, pers. comm., 1994).

Occurrence: Very rare and sporadic in Sections 151-908A-23X-3 to $32 \mathrm{X}-2$; early Oligocene of Antarctica (Kerguelen Plateau).

\section{Actinomma sp. D \\ (Plate 2, Figs. 15, 16)}

Hexalonche sp. Bjørklund 1976, pl. 19, fig. 3, 4 ?

Occurrence: Section 151-913B-24R-4; also present at Site 338 (Core 17. $\mathrm{CC}$; late? Oligocene) in the Norwegian-Greenland Sea.

\section{Heterosestrum sexispinatum rotundum (Clark and Campbell)} (Plate 1, Figs. 10, 11)

Heterosestrum sexispinatum rotundum Clark and Campbell 1945, p. 21, pl. 3, fig. 9.

Heterosestrum tschujenkoi (Lipman) group Dzinoridze et al., 1978, pl. 24, figs. 4,5 only.

Remarks: $H$. sexispinatum rotundum Clark and Campbell (1945) was described from the Eocene Kreyenhagen Formation of California along the western side of the San Joaquin Valley.

The most similar forms described from the Norwegian-Greenland Sea are Heterosestrum tschujenkoi (Lipman) group and Heterosestrum(?) sp. "sph." in Dzinoridze et al. (1978, pl. 24, figs. 1-5 and pl. 24, fig. 6/pl. 35, figs. 5, 6, respectively). At least three of these specimens, Figs. 1, 2, and 6, differ by having at least one more "ring" or medullary shell. The original definition of Heterosestrum denotes the presence of only two medullary shells, therefore either their forms should be questionably assigned to Heterosestrum, or the definition of this genus requires emendation. Dzinoridze et al.'s figure 3 on plate 24 appears to be a member of the type species, Heterosestrum sexispinatum (Clark and Campbell, 1942, p. 45, pl. 3, fig. 7).

Occurrence: Common in Section 151-913B-27R-5; see Table 3 for other occurrences.

\section{Hexacontium hexactis(?) (Stöhr)}

(Plate 1, Figs. 7, 8)

Actinomma hexactis Stöhr 1880, p. 91, pl. II, fig. 7.

Hexacontium hexactis (Stöhr) Dumitrica, 1978, p. 236, pl. 1, fig. 12.

Remarks: This specimen is questionably assigned to $H$. hexactis because the forms illustrated by Stöhr (1880) and Dumitrica (1978) are Miocene in age and have slightly larger pores than the specimen figured herein.

Occurrence: Single specimen in Core 151-913B-25R.

Hexacontium sp.

(Plate 2, Figs. 1, 2)

Remarks: This form is characterized by a relatively thin cortical shell with large, regular pores.

Occurrence: Rare in Cores 151-908A-21X and 22X.

\section{Lithelius sp. aff. L. nautiloides Popofsky}

(Plate 2, Fig. 3)

Remarks: This specimen has fewer whorls which are more loosely coiled than $L$ nautiloides Popofsky (1908), resulting in a more irregular external outline. Kling (1973) used the genus Spirema (Haeckel) for similar forms, but excluded the use of that name to specimens which had a smooth outer wall lacking radial spines. The forms found herein do have thin radial spines penetrating the external wall.

Occurrence: Rare in Sections 151-908A-20X-5 and 22X-3.

Lithelid gen. et spp. indet.

(Plate 2, Figs. 4-6, 12, 14, 17)

Remarks: This large group is currently under study by I. Popova and D. Lazarus (Popova and Lazarus, pers. comms., 1994; 1995). All possess an internal structure composed of 3-dimensional whorls wrapping around the cen- tral portion of the test in more than one plane and direction. As a consequence, diagnosis of these morphotypes requires viewing the specimens from different angles, inasmuch as one angle may produce a simple "bulls-eye" type pattern and another produce a view of the whorl coiling outward from the center of the test.

Specimens of this type have been referred to in the literature as Larcopyle, Larcospira, and Pylospira. It is likely that there is significant overlap with the genus Lithelius as well. Tests with similar structure but denser, spongier meshworks have been included herein under "Spongurus(?)," but they also may be related. Full understanding of this group awaits completion of detailed taxonomic studies.

Occurrence: Rare to very abundant throughout Paleogene sections at Sites 908 and 913.

\section{Porodiscus(?) sp. \\ (Plate 2, Fig. 7)}

Porodiscus? sp. Lazarus and Pallant, 1989, p. 368, pl. 8, fig. 20 only.

Remarks: This morphotype differs from Stylotrochus charlestonensis (Clark and Campbell) figured by Sanfilippo and Riedel (1973) by having more circular central rings and external spines with broader, more blade-like bases that narrow to a point within a short distance from the test.

Occurrence: Single specimen in Section 151-913B-26R-2. Also known from the Labrador Sea, Core 105-647A-20-2 (early Oligocene).

\section{Prunopyle(?) sp. aff. P. haysi Chen \\ (Plate 2, Figs. 8, 9)}

Remarks: This morphotype differs from $P$. haysi Chen in having a very weakly developed pylome and subcircular to polygonal, rather than hexagonal, aligned pore frames. Pores become more irregularly arranged towards the center of the test.

Use of the generic name Prunopyle has been questioned by some workers. Petrushevskaya (1975) preferred Ommatodiscus from Stöhr (1880). Russian workers have established the genus Spiromultitumica for egg-shaped (as opposed to disc-shaped) forms with Ommatodiscus-like test structure (I. Popova, pers. comm., 1994).

Occurrence: Single specimens from Cores 151-908A-21X to 28X.

\section{Prunopyle(?) sp.}

(Plate 2, Fig. 13)

Remarks: These specimens are characterized by having a circular test in plan view. In general, the rings are slightly farther apart than in $P$. haysi (e.g., Chen, 1975, pl. 9, fig. 4), the pylome is weakly developed, if present at all, and the aligned pore frames are polygonal to subcircular.

Occurrence: Very rare to few specimens per sample from Sections 151913B-24R-3 to $27 \mathrm{R}-5$.

\section{Sphaerostylus cristatus Blueford group}

(Plate 3, Figs. 6, 7)

Sphaerostylus cristatus group Lazarus and Pallant, 1989, pl. 6, figs. 16-19. Sphaerostylus cristatus Blueford, 1982 (part), pl. 1, fig. 1.

?Xiphostylus minimum Mamedov, 1969, pl. 1, fig. 1.

?Stylosphaera (Stylosphaerantha) minor minor Clark and Campbell, 1942, pl. 5 , fig. 1, 2, 2a.

Remarks: Blueford (1982, p. 199-200) named this species for spumellarians with two concentric shells (outer shell with small, circular, equal-sized pores, closely packed), and two unequal conical spines. As noted by Lazarus and Pallant (1989, p. 364), this is a very large grouping of specimens with generally similar shells which may or may not be related. The specimen figured herein is more like Blueford's paratype (pl. 5, fig. 9), which lacks thorny spines on the surface of the cortical shell.

Clark and Campbell (1942) figured a similar form as Stylosphaera minor minor from the Eocene of California. S. minor minor is distinguished from $S$. cristatus by having equal-length spines; unfortunately, the forms discovered herein have at least one broken spine per specimen and thus no comparison to that species can be made. Petrushevskaya (1979) does not figure her specimens assigned to Stylosphaera minor Clark and Campbell, but notes their occurrence at Site 338 (Core 26), Site 340 (Cores 6 and 9) and Site 339 (Core 12).

Occurrence: Sections 151-913B-26R-1 and 27R-4; see Table 3 for other occurrences. 
Spongocore sp.

(Plate 3, Fig. 14)

Amphymenium splendiarmatum Clark and Campbell group, Petrushevskaya, 1975, pl. 7, fig. 1.

?Spongocore group Mullineaux and Westberg-Smith, 1986, pl. 1, fig. 13. Spongocore spp. Lazarus and Pallant, 1989, p. 367, pl. 8, figs. 1, 2.

Remarks: The form figured herein is similar to some morphotypes assigned to Amphymenium splendiarmatum Clark and Campbell (1942). It differs from the type specimens by having a broader test with larger pores that inflates at its distal ends and is slightly curved. These are considered intraspecific differences by some authors. In addition to the single form illustrated by Petrushevskaya from Leg 29 (above), other specimens assigned to A. splendiarmatum have been recorded from DSDP Leg 10 material (Sanfilippo and Riedel, 1973) and the Rockall Plateau (Westberg-Smith and Riedel, 1984).

Occurrence: Sections 151-913B-24R-1 and 2 only; see Table 3 for other occurrences.

\section{Spongotrochus americanus Kozlova and Gorbovets}

(Plate 3, Fig. 1)

Spongotrochus americanus Kozlova and Gorbovets, 1966, p. 88.

Remarks: Kozlova and Gorbovets (1966) note that S. americanus is similar to Clark and Campbell's (1942) Spongodiscus communis. The only apparent differences are that the rings are better defined and more pronounced in $S$. communis. In contrast, the test of $S$. americanus has a spongier appearance.

Occurrence: Cores 151-908A-22X to 29X; see Table 3.

Spongurus(?) spp. A group

(Plate 2, Figs. 10, 11; Plate 3, Fig. 15)

Remarks: These specimens have a similar appearance to Spongurus cauleti Goll and Bjørklund (1989), but are smaller, have tighter whorls, denser meshwork and lack the stout lattice bars radiating from the central region as described for that species. Short spines do extend from the pylome region on one end of the test in this species group.

Occurrence: Rare to common in Sections 151-913B-24R-4 to 27R-5.

\section{Spongurus(?) spp. B group}

(Plate 3, Figs. 10, 11)

Remarks: These specimens differ from $S .($ ?) spp. A group by having looser, less dense whorls and smaller size. This group and other similar forms (e.g., "Lithelid gen. et sp. indet, herein) are under study by I. Popova and D. Lazarus (I. Popova, pers. comm., 1994).

Occurrence: Very rare and sporadic in Sections 151-909A-26X-3 to $30 \mathrm{X}-3$.

\section{Spongurus spp. C group \\ (Plate 3, Figs. 12, 16)}

Remarks: These forms are composed of a dense, spongy meshwork, and have no regular internal structure discernible. Some specimens have short spines extending from the periphery; others have a "spiny" surface texture.

Occurrence: Sections 151-913B-25R-6 to 27R-5.

\section{Stylodictya aculeata Jørgensen}

$$
\text { (Plate 3, Fig. 5) }
$$

Stylodictya aculeata Jørgensen 1905, p. 119, pl. 10, fig. 41

Stylodictya stellata Bailey group Petrushevskaya, 1975, p. 576, pl. 6, fig. 9. Stylodictya stellata Bailey group Dzinoridze et al., 1978, pl. 25, fig. 1 .

Occurrence: Core 151-913B-24R-1. Also present at Site 339 (Core 12) in the Norwegian-Greenland Sea.

\section{Stylodictya validispina Jørgensen group} (Plate 3, Fig. 17)

Stylodictya validispina Jørgensen 1905, p. 119, pl. 10, fig. 40.

Remarks: This group encompasses a wide variety of similar morphotypes. Efforts to distinguish between some of these different subgroups can be found in Boltovskoy and Vrba (1988).

Occurrence: Wash Core 151-913B-19W. Worldwide, Miocene to Recent.
Stylodictya targaeformis (Clark and Campbell)

(Plate 3, Fig. 13)

Staurodictya targaeformis Clark and Campbell 1942, p. 43, pl. 3, fig. 6.

Stylodictya targaeformis (Clark and Campbell) Petrushevskaya and Kozlova,

1972, p. 526, pl. 18, fig. 9; Petrushevskaya, 1975, p. 576, pl. 6, figs. $7,8$.

Stylodictya targaeformis (Clark and Campbell) rosella Kozlova, Dzinoridze et al., 1978, pl. 25, fig. 3 .

Occurrence: Sections 151-913B-24R-4 to 27R-2. Cosmopolitan, with a full range of middle Eocene to early Miocene (J.-P. Caulet, pers. comm. 1994).

\section{Stylatractus sp. A}

(Plate 3, Figs. 2-4)

Stylatractid sp. E Lazarus and Pallant, 1989, pl. 6, figs. 21, 22, 28.

Remarks: These forms are similar to those described by Lazarus and Pallant (1989, p. 364), with the exceptions that all of these forms possess a moderately to very well-developed third three-bladed spine extending from the medullary shell. Further, the angle between the third spine and the smaller axial spine is not as acute, approaching $90^{\circ}$ in some specimens.

Dzinoridze et al. (1978) present an illustration with affinities to this form from Site 339 (Core 7; pl. 22, fig. 4). They assign that specimen to Amphisphaera spinulosa (Ehrenberg), but other specimens assigned to $A$. spinulosa (e.g., Dzinoridze et al., pl. 22, fig 5; see also Petrushevskaya, 1979, figs. 236 237) are not the same as this form, possessing multiple radial beams and spines extending from the cortical shell.

Occurrence: Rare to common, but sporadic, in Sections 151-913B-24R3 to $26 \mathrm{R}-3$. Hole $647 \mathrm{~A}$ in the Labrador Sea, Oligocene to early Miocene.

\section{Stylatractus sp. B \\ (Plate 3, Figs. 8, 9)}

Remarks: The closest form to this illustrated thus far from the Norwegian-Greenland Sea is Amphisphaera(?) spinulosa Ehrenberg (in Dzinoridze et al., 1978, pl. 22, fig. 9, 8?) which appears to have two medullary shells and smooth, rather than triradiate, spines.

Occurrence: Very rare in Sections 151-913B-25R-1 to 26R-1.

$$
\begin{array}{r}
\text { Tetrapyle(?) sp. A } \\
\text { (Plate 4, Figs. 1, 7) }
\end{array}
$$

Remarks: These specimens are similar to Tetrapyle(?) spp. described from the Labrador Sea by Lazarus and Pallant (1989), but are less ellipsoidal and have a greater number of radial beams connecting the outermost medullary shell to the cortical wall. Many of these beams extend through and beyond the cortical wall as short spines.

Occurrence: Rare to common, Sections 151-913B-24R-3 to 27R-5.

$$
\begin{gathered}
\text { Tetrapyle(?) sp. B } \\
\text { (Plate 4, Fig. 17) }
\end{gathered}
$$

\section{Phorticium sp. Bjørklund, 1976, pl. 20, figs. 4-6.}

Remarks: Tetrapyle(?) sp. B is characterized by its thick, sturdy outer cortical wall, girdle bands with large, circular to subcircular pores, and radial beams which widen as they extend from the medullary shell to their point of attachment along the cortical wall. The outline of the cortical shell is flattened and irregular; the medullary shell is ellipsoidal. Several of the radial beams and parts of the girdle attachments extend through the cortical wall, forming short spines on the exterior of the test.

Occurrence: Rare in Sections 151-908A-21X-1 to 34X-4. Site 338, Cores 19 to 21 .

\section{NASSELLARIA}

\section{Amphipternis sp.}

(Plate 4, Fig. 19)

Remarks: Amphipternis Foreman was established for amphipyndacids with cephalic structures that descend into the thoracic cavity and do not form a separate chamber, as is typical of the type genus Amphipyndax. Foreman chose Amphipternis clava (Ehrenberg) as the type species (Foreman, 1973, p. 430). Although difficult to see on this specimen, there do not appear to be two cephalic chambers. 

70-72.

Occurrence: Single specimen discovered in Sample 151-908A-20X-5; Antarctissa robusta Petrushevskaya

(Plate 4, Figs. 10, 15

Antarctissa robusta Petrushevskaya, 1975, p. 591, pl. 11, figs. 21, 22; Lazarus and Pallant, 1989, p. 358, pl. 1, figs. 20-22.

Antarctissa(?) capitata Popofsky group Petrushevskaya, 1975, pl. 11, fig. 24. ?Antarctissa equiceps Campbell and Clark group Petrushevskaya, 1975, pl. 11 , figs. 23 and 25 .

Antarctissa antedenticulata Chen, 1975, pl. 18, figs. 1 and 2.

Occurrence: Wash Core 151-913B-19W (middle Miocene). See Table 3 for other occurrences.

\section{Artostrobus quadriporus Bjørklund}

(Plate 4, Fig. 12)

Artostrobus quadriporus Bjørklund, 1976, pl. 23, figs. 15-21.

Lithamphora sp. aff. Corocalyptra kruegeri Popofsky, Dzinoridze et al., 1978, pl. 32, fig. 12? 13-15.

Lithamphora quadripora (Bjørklund) Petrushevskaya, 1979, p. 149, figs. 358 , 479-481, 536

not?Artostrobus quadriporus Bjørklund, Lazarus and Pallant, 1989, p. 362 , pl. 5, figs. 16, 17.

Remarks: As noted by Lazarus and Pallant (1989, p. 362), a form similar to A. quadriporus Bjørklund was described by Bailey (1856, p. 4, pl. I, fig. 5a, b) as Cornutella? annulata B (type species of Artostrobus Haeckel) in sediments collected from the Sea of Kamchatka. The latter species is described as "...elongated digitiform or somewhat conical, with rounded apex and terminal spine...[pores] four to six being visible at once in each ring."

Forms figured from Leg 38 material by Bjørklund (1976) are more broadly subconical and shorter than Bailey's forms, do have four to five pores per transverse row, but only weakly developed apical and external spines. Bjørklund's specimens appear to have a minimum of three segments; it is not easy to distinguish the number of segments in Bailey's forms. In contrast, the morphotype illustrated by Lazarus and Pallant from the Labrador Sea has an elongate two-segmented cylindrical test with three pores visible per row, a very well developed apical horn, and two well-developed external spines or "wings" extending from the cephalic skeletal elements. All three of these forms are no doubt related, but inasmuch as this author has only seen morphotypes similar to Bjørklund's figured specimens in the Norwegian-Greenland $\mathrm{Sea}, A$. quadriporus herein is considered distinctive from the Labrador Sea morphotypes.

Occurrence: Rare to abundant in Sections 151-913B-24R-4 to 26R-3. See Table 3 for other occurrences.

\section{Artostrobus(?) sp.}

(Plate 4, Figs. 13, 14)

Remarks: These morphotypes are questionably assigned to Artostrobus inasmuch as they also bear a small resemblance to the genus Eurystomoskevos Caulet (1991, p. 536). They differ from the latter by having a weakly distinct, rather than indistinct, cephalis, and a thorax which flares only slightly at its terminus. Primary lateral and dorsal spines in the specimens from Site 913 cannot be seen extending through the walls except on rare, better preserved specimens. These differences may be very minor, but further study on wellpreserved specimens is needed.

A form similar to this was figured by Clark and Campbell (1942) as Lithomelissa (Acromelissa) acutispina Clark and Campbell (p. 69, pl. 9, fig. 21). Their morphotype, however, does not flare distally and has more numerous, smaller pores. Although they describe their morphotype as having "free lateral wings," they do not illustrate the internal structure and it is impossible to determine if the wings extend from the thorax wall or are extensions of primary spines.

Occurrence: Sections 151-913B-24R-4 to 26R-3. Also present in Sample 38-338-28-3; 130-133 cm, from the Norwegian-Greenland Sea (Hull, pers. obs., 1994).

Botryocampe sp.

(Plate 4, Fig. 8)
Remarks: These specimens are characterized by their large multi-lobed cephalis. The thorax is broken in many specimens, but appears to be one half the size of the cephalis or smaller in most samples.

Occurrence: Sections 151-913B-25R-6 to Core 151-913B-27R-5.

\section{Botryopera(?) pseudoantarctissa Petrushevskaya} (Plate 4, Figs. 2-4)

Botryopera(?) pseudoantarctissa Petrushevskaya, 1979, p. 124, figs. 331338,471

Occurrence: Sections 151-913B-25R-7 to 26R-1. Also present at Site 343 (Core 5) in the Norwegian-Greenland Sea and at Site 338 (Sample 38338-23-6; 104-106 cm; Hull, pers. obs., 1994).

Botryostrobus joides Petrushevskaya group (Plate 4, Figs. 5, 6, 20)

Botryostrobus joides Petrushevskaya, 1975, p. 585, pl. 10, fig. 37; Bjørklund, 1976, pl. 23, figs. 7-14; Dzinoridze et al., 1978, pl. 29, fig. 8; Caulet, 1991 , p. 537.

Botryostrobus sp. B Dzinoridze et al., 1978, pl. 32, fig. 29 only (not fig. 28). Botryostrobus joides Petrushevskaya narratus Petrushevskaya 1979, p. 148 , fig. 361.

Remarks: Within this group are forms with various numbers, sizes and shapes of segments. Also included are several different types of apical "horns," which range from single broad, rounded or sharply pointed apical horns to what is better referred to as a "crown of thorns" covering the surface of the cephalis and at least the apical portion of the thorax.

The type species of Botrystrobus joides is described by Petrushevskaya (1975), who notes that the "...surface of the cephalothorax is rather rough" (p. 585). Her figured specimen is cut off directly at the top, thus it is impossible to see what, if any, type of horn was present. Illustrated herein from Section 913B-24R-1 (earliest Oligocene), is a specimen that lacks a true horn but has a thickened apical surface that may be described as "rather rough," and thus is also included in this species. At Site 913B, stratigraphically older assemblages show increasing complexity, from a rough, hornless apical surface to a single horn, then finally to the "crown of thorns."

Occurrence: Occurs sporadically in Sections 151-913B-24R-1 to 32R-3. See Table 3 for other occurrences.

\section{Botryostrobus sp. aff. B. kerguelensis Caulet} (Plate 4, Fig. 18)

Remarks: The specimen figured herein shares its small size, rough-surfaced shell, short vertical horn and obliquely upward-directed vertical tube with $B$. kerguelensis Caulet, which ranges from the Eocene to early Miocene of the Kerguelen Plateau (Caulet, 1991, p. 535). It differs by having a broader test that becomes more inflated distally, lending the test a more conical, rather than cylindrical, appearance. Strictures are not well developed, and wellaligned transverse pore rows do not become apparent until the abdominal and subsequent segments.

Two other similar morphotypes from the northern hemisphere have been observed. A specimen from early Oligocene sediments of the Labrador Sea (647A-21-2; 13-16 cm; Hull, pers. obs. of D. Lazarus collection, 1994) is nearly identical to the form illustrated herein. A related species with a much broader thorax is present in Site 338 sediments in the Norwegian-Greenland Sea (Sample 338-29-3; 129-131, middle Eocene; Hull, pers. obs. of Microfossil Reference Collection, Scripps Institute, 1994).

Occurrence: Core 151-913B-25R-1, and 25R-5). See Table 3 for other occurrences.

\section{Calocyclas talwanii Bjørklund and Kellogg} (Plate 4, Figs. 11, 16)

Calocyclas talwanii Bjørklund and Kellogg, 1972, pl. 1, fig. 1; Bjørklund, 1976, pl. 21, figs. 1-3.

Clathrocyclas(?) extensa (Clark and Campbell) talwanii (Bjørklund and Kellogg) Dzinoridze et al., 1978, pl. 27, figs. 1, 2; pl. 34, figs. 8-10.

Remarks: The specimens discovered in this study are very poorly preserved, derived from the base of the biosilica-bearing interval at Site 913. Calocyclas talwanii differs from Calocyclas extensa Clark and Campbell by possessing a broader and longer thorax. C. talwanii does, however, bear close 
resemblance to the subspecies Calocyclas (Calocycletta) extensa contracta Clark and Campbell (1942, pl. 8, figs. 15, 16). This subspecies of $C$. extensa (documented previously from both California and the Norwegian-Greenland Sea) has the same general test outline as the holotype of $C$. talwanii, a long, stout apical horn, and possesses an abdomen that constricts in the distal third of the test, a characteristic of both Clark and Campbell's subspecies and $C$. talwanii.

Occurrence: Rare specimens in Cores 151-913B-31R to 32R. See Table 3 for additional occurrences.

$$
\begin{aligned}
& \text { Ceratocyrtis sp. cf. C. cucullaris (Ehrenberg) } \\
& \text { (Plate 4, Fig. 9) }
\end{aligned}
$$

Remarks: This morphotype differs from C. cucullaris (Ehrenberg, 1875, taf. 2, fig. 7) by having a weakly developed collar and slightly flared thorax, and by lacking a distinctive apical horn and more uniform-sized pores, as in the type species.

Occurrence: Section 151-913B-26R-1.

\section{Ceratocyrtis mashae Bjørklund}

(Plate 5, Figs. 3, 4)

Ceratocyrtis mashae Bjørklund, 1976, p. 1125, pl. 17, figs. 1-5; Abelmann, 1990 , p. 694 , pl. 4 , figs. 15 a, b, c).

Occurrence: Single specimen in Section 151-908A-30X-2. See Table 3 for other occurrences.

\section{Ceratocyrtis stigi (Bjørklund)}

(Plate 5, Figs. 1, 2)

Lithomelissa sp. C Chen, 1975, p. 458, pl. 11, figs. 3?, 4.

Lithomelissa stigi Bjørklund, 1976, p. 1125, pl. 15, figs. 12-17.

Ceratocyrtis panicula Petrushevskaya in Petrushevskaya and Kozlova, 1972, p. 115, fig. 289.

Ceratocyrtis stigi (Bjørklund) Nigrini and Lombari, 1984, p. N13, pl. 15, fig. 7; Abelmann, 1990, p. 694, pl. 4, fig. 12;

es.

Occurrence: Section 151-908A-22X-1. See Table 3 for other occurrenc-

\section{Cornutella clathrata Ehrenberg}

(Plate 5, Fig. 13)

Cornutella clathrata Ehrenberg, 1838 , p. $129 ; 1844$, p. $77 ; 1847$, p. $42 ; 1854$ a, pl. 22, figs. 39a-c; 1854b, p. 1183; Abelmann, 1990, p. 696, pl. 8, fig. 8 . Cornutella clathrata alpha Ehrenberg, 1858, p. 31

Cornutella curvata Haeckel, 1887, p. 1183.

Cornutella profunda Ehrenberg group Petrushevskaya, 1975, p. 587, pl. 13, fig. 33 only.

Cornutella sp. Bjørklund, 1976, pl. 15, fig. 23.

Occurrence: Wash Core 151-913B-19W; middle Miocene. Site 338, Section 8-3 (middle Miocene) in the Norwegian-Greenland Sea. In Antarctica: Sites 689,690, late middle Miocene and younger.

\section{Cornutella sp. aff. C. californica Campbell and Clark} (Plate 5, Fig. 6)

Cornutella sp. aff. C. californica Campbell and Clark, Bjørklund, 1976, pl. 23, figs. 23, 24; Dzinoridze et al., 1978, pl. 32, fig. 30; Petrushevskaya, 1979, figs. $261-263,535$.

Remarks: This form was incorrectly referred to as $C$. sp. aff. C. californica Clark and Campbell (1942), by Bjørklund (1976) and Dzinoridze et al. (1978). The nominal species, Cornutella californica, was named by Campbell and Clark (1944) from Upper Cretaceous assemblages collected near Tesla, California.

Occurrence: Sections 151-913B-24R-2 to 27R-3. Also Sites 339 (Cores 11 and 12 ) and 340 (Core 3 ) in the Norwegian-Greenland Sea.

\section{Cornutella profunda Ehrenberg group} (Plate 5, Fig. 17)

Cornutella clathrata? beta profunda, Ehrenberg, 1854a, p. 241; 1854b, p. 60; Bailey, 1856, p. 6, fig. 23; Dzinoridze et al., 1978, pl. 26, fig. 8. Cornutella profunda Ehrenberg, 1858, p. 31; 1862, pl. 17, fig. 5 .
Remarks: A number of different morphotypes are described in the literature under the species name "Cornutella profunda" Ehrenberg. Although the type species was described from Quaternary sediments, the definition of $C$. clathrata? beta profunda (in Ehrenberg, 1854a, p. 241; translation in Foreman and Riedel, 1972) is written broadly enough to include this morphotype. The characteristic distinguishing this form from $C$. sp. aff. $C$. californica is the more inflated apical portion of the test.

Occurrence: Sections 151-913B-24R-4 to 26R-2. Site 339, Core 12-3 in the Norwegian-Greenland Sea.

\section{Cornutella sp. \\ (Plate 5, Fig. 7)}

Remarks: These specimens are distinguished by their very slender elongated tests and, in well-preserved specimens, extremely long apical horns.

Occurrence: Core 151-913B-27R (Section 3 only).

$$
\begin{gathered}
\text { Corythospyris palmipodiscus (Petrushevskaya) } \\
\text { (Plate 5. Fig. 14) }
\end{gathered}
$$

Ceratospyris sp. Bjørklund, 1976, pl. 23, fig. 22.

Triceraspyris palmipodiscus Petrushevskaya, 1979, p. 156-157, figs. 249, 475.

Remarks: C. palmipodiscus is the most common trissocyclid recovered from Site 913 on the eastern Greenland margin. There are a number of small variations within the group, but all are considered intraspecific herein.

There are close similarities between the tests of $C$. palmipodiscus (Petrushevskaya) and $C$. fiscella Goll that require further study to determine whether or not these morphotypes may in fact be the same species (R.M. Goll, pers. comm., 1995). In general, Petrushevskaya's species description is based largely on external features, whereas Goll's trissocyclid taxonomy relies strongly on detailed study of the external and internal structure from different views of the test.

Occurrence: Sections 151-913B-24R-5 to 27R-5; late Eocene to early Oligocene. Core 151-908A-23X; late early Oligocene to early late Oligocene. See Table 3 for other occurrences.

\section{Cycladophora sp. cf. C. conica Lombari and Lazarus (Plate 5, Fig. 15)}

Remarks: $C$. sp. cf. $C$. conica appears to have a more pronounced collar stricture and curves gently inwards towards the central axis of the test on the most distal part of the thorax. The nominal species, $C$. conica (Lombari and Lazarus, 1988, p. 105-106, pl. 3, figs. 1-16) ranges from the early Oligocene (Leg 119) to Miocene.

Occurrence: Section 151-908A-33X-1

\section{Eucyrtidium(?) sp.}

(Plate 5, Fig. 5)

Remarks: This is an undescribed species from the Eocene of the Norwegian-Greenland Sea. The test is small, with three (possibly four) segments. Cephalis rounded with a spike-like apical horn; thorax and abdomen increasing rapidly in width to form a broadly conical test. Pores do not appear to be aligned either in transverse or longitudinal rows. It is questionably assigned to Eucyrtidium herein.

Occurrence: Single specimen from Section 151-913B-32R-3.

$$
\begin{aligned}
& \text { Lipmanella sp. } \\
& \text { (Plate 5, Fig. 10) }
\end{aligned}
$$

Lipmanella sp. aff. L. insectum (Haeckel) Petrushevskaya, 1979, p. 119, fig. 319 only.

Remarks: Lipmanella sp. herein is characterized by: (1) the lack of a stricture between the cephalis and thorax; (2) steeply sloping shoulders of the thorax; (3) well-developed "wings" on both sides of the test; and (4) a weakly developed lumbar stricture.

Occurrence: Section 151-908A-31X-CC

Lithomelissa sp.

(Plate 5, Figs. 8, 9 ) 
Remarks: This species of Lithomelissa is distinguished by its well-developed lateral spines. The closest form figured from the Norwegian-Greenland Sea is Clathromitra sp. in Petrushevskaya (1979, p. 117, fig. 303), which differs in having less robust spines which are longer and directed downward at a steeper angle.

Occurrence: Sections 151-908A-30X-5 and 32X-2.

Lophocyrtis andriashevi (Petrushevskaya)

(Plate 5, Figs. 11, 12, 16)

Theocyrtis andriashevi Petrushevskaya 1979, p. 145, figs. 392 and 525.

Remarks: The generic assignment of this and subsequent species has been made to the genus Lophocyrtis as emended by Sanfilippo (1990). Her new definition includes a structurally diverse group of radiolarians, principally from the southern high latitudes to tropical regions, which are related phylogenetically. By her definition, "This genus comprises Lophocyrtis jacchia and all of its descendants. Most of its members have three segments with the pores of the thorax regularly quincuncially arranged and many have an apical horn, three feet and the third segment closed. However, the structural diversity of the forms constituting this lineage...precludes a definition based on morphological features" (Sanfilippo, 1990, p. 298-300). Use of the genus name herein is based on the premise that the morphotypes herein are related to that lineage. However, further study of better preserved specimens from the northern high latitudes is needed.

L. andriashevi was described in 1979 by Petrushevskaya (p. 145, in Russian) for forms having an inflated lower thorax, long apical horn, cylindrical to barrel-shaped thorax, lumbar stricture but a smooth transition between the thorax and cephalis. Other characteristics include number of pores per row, sizes of pores, and measurements of the test itself. However, Petrushevskaya also illustrated two morphotypes (fig. 392 and 525) with very differently shaped thoraces.

The specimen illustrated herein is most similar to her Figure 392, having a campanulate and relatively long thorax. The second specimen (in Petrushevskaya, Figure 525) has a shorter, compressed campanulate shape, and may be more similar to some specimens assigned to Clark and Campbell's (1945) Theocyrtis litos. Petrushevskaya's only differentiation between andriashevi and litos (p. 145, in Russian), is that the latter is characterized by larger dimensions and "certain other details."

Occurrence: Sections 151-913B-25R-3 to 25R-7; also known from Site 339 . Core $12(-3)$ in the Norwegian-Greenland Sea.

$$
\begin{gathered}
\text { Lophocyrtis litos (Clark and Campbell) group } \\
\text { (Plate 6, Fig. 10) }
\end{gathered}
$$

Calocyclas litos Clark and Campbell, 1945, p. 44, pl. 6, figs. 13, 20.

Calocyclas sp. Bjørklund, 1976, pl. 22, fig. 1, 2.

Theocyrtis litos (Clark and Campbell) forma Cr, Dzinoridze et al., 1978, pl. 28 , fig. 1.

Theocyrtis litos (Clark and Campbell) forma U, Dzinoridze et al., 1978, pl. 28, fig. $2, ? 11$.

Theocyrtis litos (Clark and Campbell) Dzinoridze et al., 1978, pl. 28, fig. 6.

Theocyrtis sp. Dzinoridze et al., 1978, pl. 28, fig. 7.

Theocyrtis litos (Clark and Campbell) forma A, Dzinoridze et al., 1978, pl. 28, fig. 10.

Theocyrtis litos (Clark and Campbell) Petrushevskaya, 1979, p. 145, figs. 391, 522-524.

Remarks: Lumped together within this group are two morphotypes that might be considered end members with numerous morphological variations in between. The two end members are best illustrated by the type specimens in Clark and Campbell (1945, pl. 6, figs. 13, 20), which have an asymmetrical, conically shaped thorax and cephalis, and "Theocyrtis litos (Clark and Campbell) forma Cr" in Dzinoridze et al. (pl. 28, fig. 1), which is only slightly asymmetric and whose thorax is much more campanulate in outline. Because the two forms do appear to grade into one another and because preservation of these forms in the Leg 151 material is not exemplary, no attempt to separate them is made herein.

Occurrence: Sections 151-913B-27R-1 to 27R-3. See Table 3 for other occurrences.

Lophocyrtis norvegiensis (Bjørklund and Kellogg)

(Plate 6, Figs. 11, 12)

Lophocorys norvegiensis Bjørklund and Kellogg, 1972, p. 388, pl. 1, figs. 2, 7; Bjørklund, 1976, pl. 21, fig. 11.
Lophocorys(?) norvegiensis Bjørklund and Kellogg, Dzinoridze et al., 1978, pl. 28, figs. 17, 18; pl. 34, figs. 2, 3 .

Artobotrys norvegiensis (Bjørklund and Kellogg) Petrushevskaya, 1979, figs. $394,395$.

Lophocyrtis norvegiensis (Bjørklund and Kellogg) Westberg-Smith and Riedel, 1984, p. 493, pl. 6, fig. 7.

Remarks: L. norvegiensis differs from Lophocyrtis biaurita (Ehrenberg) in its test size ( $L$. norvegiensis is larger) and pore size and density ( $L$. norvegiensis has larger and more numerous pores; Bjørklund and Kellogg, 1972, p. 388-389). As noted by Bjørklund and Kellogg (1972) and other workers (A. Sanfilippo, pers. comm., 1995), these criteria may be ecologically controlled and therefore not suitable for distinguishing separate species. Both forms cooccur and are distinguished from one another on the Rockall Plateau (Westberg-Smith and Riedel, 1984; Leg 81) and in the Norwegian-Greenland Sea (Dzinoridze et al., 1978, pl. 28, fig. 12). Paleogeographically their distributions do have some differences, however, with $L$. norvegiensis sensu Bjørklund and Kellogg being more typical of colder waters in the northern hemisphere. Additional coring and greater age control of Paleogene sediments from the Norwegian-Greenland Sea is necessary to determine whether this species separation has any stratigraphic value. If not, both forms should be lumped together as a single species, Lophocyrtis biaurita.

A more complex problem concerning these morphotypes is the generic assignment. Although L. norvegiensis was originally assigned to Lophocorys, this species is not closely related to the type species of Lophocorys ( $L$. cribosa Rüst, 1885, pl. 37, fig. 7). For this reason, Petrushevskaya (1979) placed $L$. norvegiensis in the genus Artobotrys Petrushevskaya (1971). Other workers (e.g., A. Sanfilippo, pers. comm., 1994, 1995) prefer Lophocyrtis, as used herein (see "Remarks" under $L$, andriashevi above). Similar forms have been described in the literature, including Lophoconus titanothericeraos Clark and Campbell (1942), a more robust 3-segmented form, and Lophophaena (Lophophaenula) auriculaleporis Clark and Campbell (1942). Both species are from the Eocene of California; the former also has been reported from the Kerguelen Plateau by Takemura (1992).

Occurrence: Cores 151-913B-30R (CC) to 32R (-2). See Table 3 for other occurrences.

\section{Lophocyrtis semipolita (Clark and Campbell) group} (Plate 6, Figs. 8, 9)

Calocyclas semipolita Clark and Campbell, 1942, p. 83, pl. 8, fig. 12, 14, $17-$ $19,22,23 ; 1945$, pl. 6, fig. 12, 14+?; Petrushevskaya, 1979, figs. 390 , ?526.

Calocyclas semipolita Clark and Campbell group Caulet, 1991, p. 537.

Remarks: This species is distinctive from other species of this genus by its knoblike cephalis separated from the relatively small thorax by a well-developed stricture. The specimens discovered herein are very close to morphotypes illustrated by Caulet (1991, p. 529-530, 532, pl. 4, fig. 9) near the Eocene/Oligocene boundary on the Kerguelen Plateau. Unfortunately, Leg 151 specimens are broken distally; thus, closure of the terminal segment, which indicates transition into $C$. asperum in the latest Eocene, cannot be determined.

Occurrence: Sections 151-913B-25R-2 to 26R-2. See Table 3 for other occurrences.

\section{Lophocyrtis sp.}

(Plate 6, Fig. 12)

Remarks: This form is distinguished by its very elongate thorax and rounded shoulders. Apical horn is short and tapers distally; stricture between thorax and abdomen is weakly developed.

Very similar forms have been seen in (1) the late Eocene Carpocanistrum azyx Zone in Barbados; (2) at Site 149, Core 32, Section 2 (late Eocene); and (3) from the middle Eocene at Site 738B (Core 17-2) in Antarctica (A. Sanfilippo, pers. comm., 1994).

Occurrence: Section 151-913B-25R-CC.

$$
\text { Lophophaena clevei Petrushevskaya }
$$
(Plate 6, Fig. 6)

Dictyocephalus sp. Cleve, 1899, p. 20, pl. II, fig. 1

Lithomelissa(?) laticeps Jørgensen, Hülsemann, 1963, p. 27, fig. 18

Lophophaena clevei Petrushevskaya, 1971, p. 107-109, pl. 57, fig. 1; Petrushevskaya, 1979 , p. $126-128$, figs. $350-353$.

Lophophaena spp. Petrushevskaya, 1971, pl. 56, figs. 9, 10, 15, in Petrushevskaya 1979 , p. 126 
Peromelissa(?) Petrushevskaya, 1971, pl. 45, fig. 10, in Petrushevskaya 1979, p. 126.

Occurrence: Cores 151-913B-26R-1 to 27R-3. Present at Sites 338, 339, 340 in the Norwegian-Greenland Sea. Worldwide.

\section{Lophophaena macrencephala Clark and Campbell}

(Plate 6, Fig. 14)

Lophophaena (Lophophaenula) macrencephala Clark and Campbell, 1945 , p. 41, pl. 7, figs. 6-9.

Lophophaena macrencephala Clark and Campbell group Dzinoridze et al., 1978, pl. 29, fig. 20.

Lophophaena macrencephala Clark and Campbell, Petrushevskaya, 1979 , p. 127 , figs. $348,349$.

Occurrence: Cores 151-913B-27R-3 to 27R-5. See Table 3 for other occurrences.

\section{Nassellarian gen. et sp. indet.}

(Plate 6, Fig. 13)

Remarks: The morphotypes identified herein as Nassellarian gen. et. sp. indet. are large, relatively indistinct nassellarians. Only two specimens have been found, both with the internal structure largely obscured. They appear to be two-segmented forms with a large, rounded cephalis having a single robust apical horn (triradiate) and one lateral spine extending through the test wall. Collar stricture is developed on only one side of the test, lending it an overall asymmetric appearance. Thorax is elongate, broad, and cylindrical on these specimens, and terminates in an open aperture. Pores are subcircular to ovate in outline, becoming progressively larger from the cephalis to the thorax. Pores are randomly arranged, not aligned.

Occurrence: Section 151-913B-24R-4.

\section{Peripyramis magnifica (Clark and Campbell)}

$$
\text { (Plate 6, Fig. 4) }
$$

Sethopyramis (Cephalopyramis) magnifica Clark and Campbell, 1942, p. 72 , pl. 8, figs. $1,5,9$.

Peripyramis magnifica (Clark and Campbell) Bjørklund, 1976, pl. 22, fig. 14 only.

Peripyramis sp. aff. $P$, magnifica (Clark and Campbell) group Dzinoridze et al., 1978, pl. 26, no. 1 .

Occurrence: Rare in Sections 151-913B-24R-4 to 27R-5. Also present at Site 339 (Core 12-2 and -3) in the Norwegian-Greenland Sea, in the middle to late Eocene of California and elsewhere worldwide.

\section{Peripyramis sp. aff. P. magnifica (Clark and Campbell)}

\section{(Plate 6, Fig. 5)}

Peripyramis magnifica (Clark and Campbell) Bjørklund, 1976, pl. 22 fig. 13 only.

?Peripyramis quadratella (Ehrenberg) Dzinoridze et al., 1978, pl. 26, fig. 3.

Peripyramis sp. aff. magnifica Clark and Campbell group Dzinoridze et al., 1978, pl. 31 , fig. 3 only.

Remarks: This morphotype is distinguished by having a broadly conical test with rectangular openings between longitudinal and transverse bars.

Occurrence: Section 151-913B-27R-1. Elsewhere in the NorwegianGreenland Sea, Site 339 (Core 12) and possibly Site 340 (Dzinoridze et al., 1978).

\section{?Pseudodictyophimus horrida Petrushevskaya}

(Plate 6, Fig. 1)

?Spongomelissa dili Chen, 1974 , p. 488 , pl. 3, figs. $8,9$.

Corythomelissa horrida Petrushevskaya, 1975, p. 590, pl. 11, fig. 14, 15; pl. 21, fig. 9; ?Takemura 1992, p. 744, pl. 3, fig. 14.

Pseudodictyophimus horrida Petrushevskaya, 1979, p. 120, figs. 305, 306.

Remarks: The specimen figured herein is partially broken at its base and lacks an apical horn (which may also be broken), making identification questionable. However, at least one other specimen has been observed that does show closure in the thorax, more like the type specimens of $P$. horrida.

Occurrence: Rare in Section 151-908A-32X-4. P. horrida is known from Site 338 (Cores -7, -8, -21), and in sediments from Antarctica, Site 278, late Oligocene to late Miocene.

\section{Pseudodictyophimus platycephalus (Haeckel)}

(Plate 6, Figs. 2, 3)

Dictyophimus platycephalus Haeckel, 1887, p. 1198, pl. 60, fig. 5.

Pseudodictyophimus sp. aff. P. gracilipes (Bailey) Bjørklund, 1976, pl. 16, fig. 1 only.

Pseudodictyophimus platycephalus (Haeckel) Petrushevskaya, 1979, fig. 307. Occurrence: Section 151-9813B-24R-4; Cores 151-908A-26X to 32X. See Table 3 for other occurrences.

\section{Pseudodictyophimus sp. A \\ (Plate 6, Fig. 7)}

Remarks: This morphotype is similar to $P$. gracilipes (Bailey), but is distinguished by its sturdy apical horn, which in well-preserved specimens is as long or longer than the thorax and cephalis combined. Three feet are circular in axial section, straight, and approximately the length of the thorax. Pores are subcircular to ovate, increasing in size from the cephalis to the distal portion of the thorax.

Petrushevskaya (1979) figured another morphotype similar to this specimen, which she assigned to the species $P$. bicornis (p. 117, fig. 310). This form differs by having a less spherical cephalis, broader test, and straighter feet that always extend from the base of the thorax.

Occurrence: Sections 151-913B-24R-4 and 5.

\section{Pseudodictyophimus sp. B}

(Plate 7, Figs. 4, 9)

Remarks: $P$. sp. B is distinguished by a long, robust, triradiate apical horn, asymmetrically placed on one side of the cephalis. Horn is massive at base, tapering distally. Thorax broad with three straight triradiate feet extending for a very short distance beyond the test. Wall of thorax is composed of large circular to subcircular pores with very thin pore frames, allowing for easy viewing of the internal skeletal elements.

Occurrence: Sections 151-908A-30X-2 to $32 \mathrm{X}-6$.

\section{Pseudodictyophimus sp. C}

(Plate 7, Figs. 7, 10)

Remarks: These differ from other species of Pseudodictyophimus by their three curved feet which extend very slightly beyond the distal edge of the thorax. Two horns present; apical horn longer in well-preserved specimens and generally more robust. $P$. sp. C is distinguished from $P$. sp. B by having a shorter and less massive horn and more rounded, less flaring thorax.

Occurrence: Very rare and sporadic from Cores 151-908A-23X to 32X.

$$
\begin{aligned}
& \text { Pseudodictyophimus(?) sp. D } \\
& \text { (Plate 7, Figs. 8, 11) }
\end{aligned}
$$

Remarks: This unusual morphotype is distinctive, but rare. The cephalis is capped with a long, sturdy, triradiate apical horn which is equal to the length of the thorax. Thorax is broad, composed of subcircular to ovate pores, and has a "multilobed" appearance. Feet appear to be straight, extending only a short distance beyond the thorax.

Occurrence: Single specimen from Core 151-908A-33X.

Genus SIPHOCAMPE Haeckel, emend. Nigrini; emend. herein

Type species: Siphocampe annulosa Haeckel, 1887, p. 1500.

Emended definition: As in Nigrini (1977, p. 254), but including artostrobiids with apical horns.

Remarks: Unlike tropical forms of Siphocampe, which do not possess apical horns (C. Nigrini, pers. comm., 1995), many of the high-latitude species observed in this study do have short apical horns, typically up to threefourths the length of the cephalis or less. It is difficult to discern the presence of vertical tubes in many of these forms, although they may be strongly reduced in size.

Range: Paleocene to Holocene.

\section{Siphocampe acephala (Ehrenberg)} (Plate 7, Figs. 1-3)

Eucyrtidium acephalum Ehrenberg, 1875, p. 70, pl. 11, fig. 5. 
Eucyrtidium? obstipum Ehrenberg, 1875, p. 70, pl. 11, fig. 17.

Lithomitra acephala (Ehrenberg) Bütschli, 1882, p. 529; Haeckel, 1887, p. 1484.

Siphocampe acephala (Ehrenberg) Nigrini, 1977, p. 254, pl. 3, fig. 5; Lazarus and Pallant, 1989, p. 363, pl. 6, figs. 10, 11; Takemura, 1992, p. 743, pl. 6, fig. 9.

Lithomitra sp. Bjørklund, 1976, pl. 23, figs. 1-3.

Lithomitra(?) sp. P Dzinoridze et al., 1978, pl. 29, figs. 3, 4; pl. 32, figs. 2-3; ?6-7; pl. 33, figs. 2,$3 ; 4$ ?

Lithomitra(?) elegans Ehrenberg group Dzinoridze et al., 1978, pl. 32, fig. 18-20.

Lithomitrella elizabethae (Clark and Campbell) plicata Petrushevskaya, 1979 , p. 153 , figs. $483-486,540-544$.

Lithomitrella elizabethae (Clark and Campbell) Petrushevskaya, 1979, p. 150, fig. 488.

Remarks: Petrushevskaya (1979) distinguished $L$ elizabethae from $S$. acephala by the former's more elongated test with smaller pores. These differences are considered minor intraspecific variations herein, and the two species are placed in synonymy.

Occurrences: Sections 151-913B-23R-1 through 27R-3; possibly lower. Other high-latitude occurrences include Sites 338 and 340 in the NorwegianGreenland Sea, Barbados (in Dzinoridze et al. 1978), Labrador Sea (Oligocene to early Miocene), and the Kerguelen Plateau (middle Eocene to Oligocene)

Siphocampe arachnea (Ehrenberg) group

(Plate 8, Fig. 12)

Lithocampe lineata Ehrenberg, 1838, p. 130 (partim).

Eucyrtidium lineatum arachneum Ehrenberg, 1861, p. 299 (partim).

Lithomitra arachnea (Ehrenberg) Riedel, 1958, p. 242, pl. 4, figs. 7, 8 .

Remarks: See Nigrini, 1977, p. 255 for complete early synonymy and discussion of related morphotypes.

Occurrence: Core 151-913B-19W; middle Miocene. Worldwide in Oligocene to Holocene sediments.

Siphocampe elizabethae (Clark and Campbell)

(Plate 8, Fig. 4)

Lithomitra elizabethae Clark and Campbell, 1942, p. 92, pl. 9, fig. 18.

Lithomitra sp. cf. L. elizabethae Clark and Campbell, Nigrini 1974, p. 1070 , pl. $1 \mathrm{M}$, figs. 14-17; pl. 4, figs. $6,7$.

Siphocampe elizabethae (Clark and Campbell) Nigrini, 1977, p. 256, pl. 3, fig. 6.

Lithomitra(?) sp. aff. Lithocampe minuta Clark and Campbell, Dzinoridze et al., 1978, pl. 29, fig. 6 .

not Lithomitrella elizabethae (Clark and Campbell) plicata Petrushevskaya, 1979 , p. 153 , figs. $418,419,483-486,540-544$.

Remarks: The concept of this species as discussed by Nigrini (1977, p. 256) is followed herein.

Occurrence: Sections 151-913B-24R-5 to 25R-6. Worldwide, early to late Eocene.

\section{Siphocampe imbricata (Ehrenberg) group}

(Plate 8, Fig. 13)

Eucyrtidium imbricatus Ehrenberg, 1873, p. 231; 1875, pl. 11, fig. 22. Lithomitra imbricata (Ehrenberg) group Petrushevskaya and Kozlova, 1972, p. 539, pl. 24, figs. 2-5.

Siphocampe imbricata (Ehrenberg) Nigrini, 1977, p. 255; Caulet, 1991. pl. 3 , fig. 13.

Remarks: S. imbricata has been identified herein in the sense of Petrushevskaya and Kozlova (1972), who assign siphocampids attaining their maximum test width in the sixth or seventh segments to this species.

Occurrence: Sections 151-913B-24R-1 to 27R-1; most abundant in the base of Core 25R and top $1 \mathrm{~m}$ of Core 26. Also present in Sample 151-908A20X-5; 70-72. As defined herein, Eocene to Oligocene worldwide.

Siphocampe minuta (Clark and Campbell) (Plate 8, Figs. 7-9)

Lithocampe (Lithocampula) minuta Clark and Campbell, 1942, p. 93, pl. 9, fig. 17.
Theocampe minuta (Clark and Campbell) Petrushevskaya, 1975, pl. 26, figs. 5,6 .

Lithomitra(?) minuta (Clark and Campbell) Dzinoridze et al., 1978, pl. 32. figs. 22-24.

Lithomitrella minuta (Clark and Campbell) Petrushevskaya, 1979, p. 154, figs. 412,$413 ; 478$ ?

Remarks: Siphocampe minuta was described in 1942 by Clark and Campbell (=Lithomitra minuta), and bears close resemblance to Lithomitra urnula, described at the same time by the same authors. Unfortunately the single illustration of the type specimen is of moderate quality at best, and $S$. urnula, as illustrated, may be a broken specimen. Thus, even the written descriptions may not give accurate pictures of the morphotypic variation of these species. As defined by Clark and Campbell, $S$. minuta is characterized by a 5 -segmented test and a constricted aperture; $S$. urnula has three segments and does not constrict distally.

In this study, $S$. minuta is used for morphotypes similar to Clark and Campbell's minuta, but including tests composed of three segments. The cephalis is small, rounded, set slightly downward into the thorax and placed just off the central axis of the test, giving the specimens a slightly asymmetric aspect. Thorax is broadly bell-shaped, stricture between thorax and abdomen generally better-developed on one side of the test. Abdomen slightly larger than thorax, expanding to greatest dimension of test, then constricting gently towards the aperture.

In some respects, this description is closer to that given by Clark and Campbell for Lithomitra urnula, with the exception that the aperture is constricted. However, if the type $L$. urnula is broken, that test bears closer resemblance to $S$. acephala, and the species name urnula may be unnecessary. Thus, because of their constricted aperture and general outline, these morphotypes are assigned to $S$. minuta. This conclusion also was reached by Petrushevskaya (1979; figs. 412, 413), who assigned three-segmented forms of this type to the species minuta.

Occurrence: Sections 151-913B-26R-6 to 29R-4. See Table 3 for other occurrences.

Siphocampe sp. cf. S. minuta (Clark and Campbell) (Plate 8, Figs. 1-3)

Remarks: $S$. sp. cf. $S$. minuta differs from the nominal species by possessing a more slender test and better developed stricture between the cephalis and thorax.

Occurrence: Cores 151-913B-27R-1 to 27R-5. Hole 647A, Core 17 from the Labrador Sea (Hull, pers. obs. of D. Lazarus collection, 1994).

\section{Siphocampe septata Petrushevskaya}

(Plate 7, Figs. 5, 6)

Lithomitrella septata Petrushevskaya, 1979, p. 152-153, figs. 415-416; 482

Occurrence: Sections 151-913B-23R-1 to 25R-4. Also present in Sample 151-908A-29X-7, 2-5 cm. See Table 3 for other occurrences.

\section{Siphocampe stathmeporoides Petrushevskaya (Plate 8, Fig. 14)}

Artostrobus sp. Cr Petrushevskaya, 1975, pl. 10, fig. 1.

Artostrobus? pusillum (Ehrenberg) Dzinoridze et al., 1978, pl. 32, fig. 9 Siphocampe stathmeporoides Petrushevskaya, 1979, pl. 150-152, figs. 410,411 .

Remarks: The most characteristic features of these species are its elongate subcylindrical test with a well-developed axobat extending more than halfway through the test in well-preserved specimens.

Occurrence: Sections 151-913B-23R-1 to 27R-3. See Table 3 for other occurrences.

Siphocampe sp. aff. S. stathmeporoides Petrushevskaya (Plate 8, Fig. 15)

Remarks: This morphotype has a more cylindrical and bullet-shaped test than is described for the type specimens of $S$. stathmeporoides. This differentiation is at least partly due to the extreme thickening of the test wall on the thorax and abdomen in this morphotype, a feature that may be ecologically controlled.

Occurrence: Sections 151-913B-24R-1 to 25R-1. 
Siphocampe sp. A

(Plate 8, Figs. 10, 11)

Remarks: Species A is characterized by the very conical apical portion of the test (cephalis and upper part of thorax), which terminates in a short, sharp apical horn. Horn extends from the "free" apical spine of the cephalic skeletal elements; its base is thickened to cover the upper half of the surface of the cephalis. Cephalis is large, approximately one-third the size of the thorax. Test reaches maximum thickness in the center of the test, and is composed of large circular to subcircular pores with polygonal pore frames.

Occurrence: Sections 151-913B-24R-1 and 27R-1. Sample 105-647A19-1, 96-100 cm, Oligocene to early Miocene of the Labrador Sea (Hull, pers. obs. of D. Lazarus collection, 1994).

Siphocampe sp. B

(Plate 8, Figs. 5, 6)

Remarks: Siphocampe sp. B represents another morphotype of Siphocampe which has a distinctive apical horn. In contrast to $S$. sp. A, these specimens have thinner, spike-like horns which appear to develop from the apical spine in close proximity to one side of the cephalic wall. The thorax is longer and more cylindrical; aperture is constricted, terminating in a smooth rim.

Occurrence: Sections 151-913B-24R-2 to 27R-1.

\section{ACKNOWLEDGMENTS}

My great thanks to a number of colleagues who helped in many aspects of this project by making their slide collections, time, knowledge, and in several cases the guest bedroom available to me: Andrea Abelmann, Kjell Bjørklund, Jean-Pierre Caulet, Bob Goll, Dave Lazarus, Catherine Nigrini, Irina Popova, and Annika Sanfilippo. Reviews by Kjell Bjørklund and Jean-Pierre Caulet aided in improving this manuscript, and I thank them for their time and effort. I also thank the entire crew of Leg 151, co-chiefs Annik Myhre and Jörn Thiede, and my shipboard biostratigraphy colleagues John Firth, Nalan Koç, Lisa Osterman, Reed Scherer, Dorothee Spiegler, and Sato Tokiyuki for all of their efforts in making Leg 151 a successful cruise. This project is funded by the U.S. Science Support Program, through Texas A\&M Research Foundation (USSSP \#151-20796b) and supported by the use of research facilities at The University of Texas at Dallas. This project also benefited from the Microfossil Reference Centers at ODP Headquarters in College Station, TX (John Firth, curator) and Scripps Institute at La Jolla, CA (A. Sanfilippo, curator).

\section{REFERENCES}

Abelmann, A., 1990. Oligocene to middle Miocene radiolarian stratigraphy of southern high latitudes from Leg 113, Sites 689-690, Maud Rise. In Barker, P.F., Kennett, J.P., et al., Proc. ODP, Sci. Results, 113: College Station, TX (Ocean Drilling Program), 675-708.

Aubry, M.-P., 1992. Late Paleogene calcareous nannoplankton evolution: a tale of climatic deterioration. In Prothero, D.R., and Berggren, W.A. (Eds.), Eocene-Oligocene Climatic and Biotic Evolution: Princeton, NJ (Princeton Univ. Press), 272-309.

Bailey, J.W., 1856. Notice of microscopic forms found in the soundings of the Sea of Kamtschatka-with a plate. Am. J. Sci., 22:1-6.

Barron, J., 1985. Diatom biostratigraphy of the CESAR 6 core, Alpha Ridge, Arctic Ocean. In Jackson, J.R., Blasco, S., and Mudie, P.J. (Eds.), Initial Geological Report on CESAR-The Canadian Expedition to Study the Alpha Ridge. Geol. Surv. Can., 84-22:137-148.

Barron, J., Larsen, B., et al., 1989. Proc. ODP, Init. Repts., 119: College Station, TX (Ocean Drilling Program).

Baldauf, J., 1992. Middle Eocene through early Miocene diatom floral turnover. In Prothero, D.R., and Berggren, W.A. (Eds.), Eocene-Oligocene Climatic and Biotic Evolution: Princeton (Princeton Univ. Press), 310326.

Benson, R.N., 1972. Radiolaria, Leg 12, Deep Sea Drilling Project. In Laughton, A.S., and Berggren, W.A., et al., Init. Repts. DSDP, 12: Washington (U.S. Govt. Printing Office), 1085-1113.
Berggren, W.A., and Prothero, D., 1992. Eocene-Oligocene climatic and biotic evolution: an overview. In Prothero, D.R., and Berggren, W.A. (Eds.), Eocene-Oligocene Climatic and Biotic Evolution: Princeton (Princeton Univ. Press), 1-28.

Berggren, W.A., and Schnitker, D., 1983. Cenozoic marine environments in the North Atlantic and Norwegian-Greenland Sea. In Bott, M.H.P., Saxov, S., Talwani, M., and Thiede, J. (Eds.), Structure and Development of the Greenland-Scotland Ridge. NATO Conf. Ser. IV, New York (Plenum), 495-548.

Bjørklund, K., and Kellogg, D.E., 1972. Five new Eocene radiolarian species from the Norwegian Sea. Micropaleontology, 13:386-396.

Bjørklund, K.R., 1976. Radiolaria from the Norwegian Sea, Leg 38 of the Deep Sea Drilling Project. In Talwani, M., Udintsev, G., et al., Init. Repts. DSDP, 38: Washington (U.S. Govt. Printing Office), 1101-1168.

Blueford, J., 1982. Miocene actinommid Radiolaria from the equatorial Pacific. Micropaleontology, 28:189-213.

Boersma, A., Premoli Silva, I., and Shackleton, N.J., 1987. Atlantic Eocene planktonic foraminiferal paleohydrographic indicators and stable isotope paleoceanography. Paleoceanography, 2:287-331.

Bohrmann, G., and Stein, R., 1989. Biogenic silica at ODP Site 647 in the southern Labrador Sea: occurrence, diagenesis, and paleoceanographic implications. In Srivastava, S.P., Arthur, M.A., Clement, B., et al., Proc. ODP, Sci. Results, 105: College Station, TX (Ocean Drilling Program), $155-170$.

Boltovskoy, D., and Vrba, A., 1988. Classification and geographic distribution of Stylodictya-type radiolarians. Micropaleontology, 34:332-340.

Brinkhuis, H., 1992. Late Paleogene dinoflagellate cysts with special reference to the Eocene/Oligocene boundary. In Prothero, D.R., and Berggren, W.A. (Eds.), Eocene-Oligocene Climatic and Biotic Evolution: Princeton (Princeton Univ. Press), 327-340.

Bütschli, O., 1882. Beiträge zur Kenntnis der Radiolarienskelette, insbesondere der der Cyrtida. Z. Wiss. Zool., 360:485-540.

Campbell, A.S., and Clark, B.L., 1944. Radiolaria from Upper Cretaceous of middle California. Spec. Pap.-Geol. Soc. Am., 57:1-61.

Cande, S.C., and Kent, D.V., 1992. A new geomagnetic polarity time scale for the Late Cretaceous and Cenozoic. J. Geophys. Res., 97:1391713951.

Casey, R.E., 1993. Radiolaria. In Lipps, J.H. (Ed.), Fossil Prokaryotes and Protists: Boston (Blackwell Scientific), 249-284.

Caulet, J.-P., 1991. Radiolarians from the Kerguelen Plateau, Leg 119. In Barron, J., Larsen, B., et al., Proc. ODP, Sci. Results, 119: College Station, TX (Ocean Drilling Program), 513-546.

Chen, P.-H., 1974. Some new Tertiary radiolaria from Antarctic deep-sea sediments. Micropaleontology, 20:480-492.

1975. Antarctic radiolaria. In Hayes, D.E., Frakes, L.A., et al., Init. Repts. DSDP, 28: Washington (U.S. Govt. Printing Office), 437513.

Clark, B.L., and Campbell, A.S., 1942. Eocene radiolarian faunas from the Mt. Diablo area, California. Spec. Pap.-Geol. Soc. Am., 39:1-112.

, 1945. Radiolaria from the Kreyenhagen Formation near Los Banos, California. Mem.-Geol. Soc. Am., 101:1-66.

Cleve, P.T., 1899. Plankton collected by the Swedish Expedition to Spitzbergen in 1898. Handl. Kgl. Svenska Vetensk.-Akad., 32:1-51.

Dell'Agnese, D., and Clark, D.L., 1994. Siliceous microfossils from the warm Late Cretaceous and early Cenozoic Arctic Ocean. J. Paleontol., 68:31-46

Dumitrica, P., 1978. Badenian Radiolaria from Central Paratethys. In Brestenska, E. (Ed.), Chronostratigraphie und Neostratotypen, Miozan der Zentralen Paratethys: 6:231-261.

Dzinoridze, R.N., Jousé, A.P., Koroleva-Golikova, G.S., Kozlova, G.E., Nagaeva, G.S., Petrushevskaya, M.G., and Strelnikova, N.I., 1978. Diatom and radiolarian Cenozoic stratigraphy, Norwegian Basin; DSDP Leg 38. In Talwani, M., Udintsev, G., et al., Init. Repts. DSDP, 38, 39, 40, 41 (Suppl.): Washington (U.S. Govt. Printing Office), 289-427.

Ehrenberg, C.G., 1838. Über die Bildung der Kreidefelsen und des Kreidemergels durch sichtbare Organismen. Abh. Kgl. Preuss. (Akad. Wiss. Berlin), 59-147.

1844. Über zwei neue Lager von Gebirgsmassen aus Infusorien als Meeres-Absatz in Nord-Amerika und eine Vergleichung derselben mit den organischen Kreide-Gebilden in Europa und Afrika. K. Preuss. Akad. Wiss. Berlin, Berichte, 57-97.

, 1847. Über eine halibiolithische, von Herrn R. Schomburgk entdeckte, vorherrschend aus mikroskopischen Polycystinen gebildete, 
Gebirgsmasse von Barbados. K. Preuss. Akad. Wiss. Berlin, Bericht, Jahre 1846:382-385

1854a. Die systematiche Charakteristik der neuen mikroskopischen Organismen des tiefen Atlantischen Oceans. K. Preuss. Akad. Wiss. Berlin, Berichte, Jahre 1854:236-250.

- 1854b. Mikrogeologie: Das Erden und Felsen schaffende Wirken des unsichtbar kleines selbständigen Lebens auf der Erde: Leipzig (Leopold Voss).

, 1858. Kurze Characteristik der 9 neuen Genera und der 105 neuen Species des agaischen Meeres und des Tiefgrundes des Mittel-Meeres. $K$. Preuss. Akad. Wiss. Berlin, Monatsberichte, 1858:10-40.

$\longrightarrow$, 1861. Uber den Tiefgrund des stillen Oceans zwischen Californien und den Sandwich-Inseln aus bis 15600' Tiefe nach Lieut. Brooke. $K$. Preuss. Akad. Wiss. Berlin, Monatsberichte, 1860:819-833.

1862. Über die Tiefgrund-Verhältnisse des Oceans am Eingange der Davisstrasse und bei Island. K. Preuss. Akad. Wiss. Berlin, Monatsberichte, 1861:275-315.

1873. Grössere Felsproben des Polycystinen-Mergels von Barbados mit weiteren Erläuterungen. K. Preuss. Akad. Wiss. Berlin, Monatsberichte, Jahre 1873:213-263

1875. Fortsetzung der mikrogeologischen Studien als GesammtUebersicht der mikroskopischen Paläontologie gleichartig analysirter Gebirgsarten der Erde, mit specieller Rücksicht auf den PolycystinenMergel von Barbados. Abh. K. Akad. Wiss. Berlin, Jahre 1875:1-225.

Ehrmann, W.U., and Thiede, J., 1985. History of Mesozoic and Cenozoic sediment fluxes to the North Atlantic Ocean. Contrib. Sedimentol., 15:1109.

Eldholm, O., and Myhre, A.M., 1977. Hovgaard Fracture Zone. AArb., Nor Polarinst., 1976:195-208.

Eldholm, O., and Thiede, J., 1980. Cenozoic continental separation between Europe and Greenland. Palaeogeogr., Palaeoclimatol., Palaeoecol. $30: 243-259$.

Fenner, J., 1985. Late Cretaceous to Oligocene planktic diatoms. In Bolli, H.M., Saunders, J.B., and Perch-Nielsen, K. (Eds.), Plankton Stratigraphy: Cambridge (Cambridge Univ. Press), 713-762.

Foreman, H.P., 1973. Radiolaria of Leg 10 with systematics and ranges for the families Amphipyndacidae, Artostrobiidae, and Theoperidae. In Worzel, J.L., Bryant, W., et al., Init. Repts. DSDP, 10: Washington (U.S. Govt. Printing Office), 407-474.

Foreman, H.P., and Riedel, W.R., 1972. Catalogue of polycystine Radiolaria. Am. Mus. Nat. Hist., Spec. Publ., Ser. 1, Vol. 1.

Goll, R.M., 1978. Five Trissocyclid Radiolaria from Site 338. In Talwani, M., Udintsev, G., et al., Init. Repts. DSDP, 38, 39, 40, 41 (Suppl.): Washington (U.S. Govt. Printing Office), 177-191.

1989. A synthesis of Norwegian Sea biostratigraphies: ODP Leg 104 on the Vøring Plateau. In Eldholm, O., Thiede, J., Taylor, E., et al., Proc. ODP, Sci. Results, 104: College Station, TX (Ocean Drilling Program), 777-826.

Goll, R.M., and Bjørklund, K.R., 1989. A new radiolarian biostratigraphy for the Neogene of the Norwegian Sea: ODP Leg 104. In Eldholm, O. Thiede, J., Taylor, E., et al., Proc. ODP, Sci. Results, 104: College Station, TX (Ocean Drilling Program), 697-737.

Grønlie, G., and Talwani, M., 1982. The free-air gravity field of the Norwegian-Greenland Sea and adjacent areas. Earth Evol. Ser., 2:79-103.

Haeckel, E., 1887. Report on the Radiolaria collected by H.M.S. Challenger during the years 1873-1876. Rep. Sci. Results Voy. H.M.S. Challenger, 1873-1876, Zool., 18:1-1803.

Haq, B.U., Hardenbol, J., and Vail, P.R., 1987. Chronology of fluctuating sea levels since the Triassic. Science, 235:1156-1167.

Hülsemann, K., 1963. Radiolaria in plankton from the Arctic Drifting Station T-3, including the description of three new species. Arct. Inst. N. Am. Tech. Pap. Arct., 13:1-52.

Johnson, G.L., and Eckhoff, O.B., 1966. Bathymetry of the North Greenland Sea. Deep Sea Res. Part A, 13:1161-1173.

Johnson, G.L., and Schneider, E.D., 1969. Depositional ridges in the North Atlantic. Earth Planet. Sci. Lett., 6:416-422.

Jørgensen, E., 1905. The protist plankton and the diatoms in bottom samples. Bergens Mus. Skr., 49-151.

Kaminski, M.A., 1988. Cenozoic deep-water agglutinated foraminifera in the North Atlantic [Ph.D. thesis]. Woods Hole Oceanogr. Inst./Mass. Inst. Technol., Joint Program in Oceanography.

Keller, G., Herbert, T., Dorsey, R., D'Hondt, S., Johnsson, M., and Chi, W.R., 1987. Global distribution of late Paleogene hiatuses. Geology, 15:199203.
Kling, S.A., 1973. Radiolaria from the eastern North Pacific, Deep Sea Drilling Project, Leg 18. In Kulm, L.D., von Huene, R., et al., Init. Repts. DSDP, 18: Washington (U.S. Govt. Printing Office), 617-671.

Kozlova, G.E., and Gorbovets, A.N., 1966. Radiolyarii verkhnemelovykh i verkhneeotsenovykh otlozhenii Zapadno-Sibirskoi Nizmennosti [Radiolaria of the Upper Cretaceous and upper Eocene of the west Siberian Lowland]. Tr. Vses. Neft. Nauchno-Issled. Geologorazved. Inst., 248:1159.

Kristoffersen, Y., 1990. On the tectonic evolution and paleoceanographic significance of the Fram Strait gateway. In Bleil, U., and Thiede, J. (Eds.), Geological History of the Polar Oceans: Arctic versus Antarctic. NATO ASI Ser., Ser. C, 308:63-76.

Lawver, L.A., Müller, R.D., Srivastava, S.P., and Roest, W., 1990. The opening of the Arctic Ocean. In Bleil, U., and Thiede, J. (Eds.), Geological History of the Polar Oceans: Arctic versus Antarctic: Dordrecht (Kluwer Academic Publ.), 29-62.

Lazarus, D., and Pallant, A., 1989. Oligocene and Neogene radiolarians from the Labrador Sea, ODP Leg 105. In Srivastava, S.P., Arthur, M.A., Clement, B., et al., Proc. ODP, Sci. Results, 105: College Station, TX (Ocean Drilling Program), 349-380.

Lombari, G., and Lazarus, D.B., 1988. Neogene cycladophorid radiolarians from North Atlantic, Antarctic, and North Pacific deep-sea sediments. Micropaleontology, 34:97-135.

Mamedov, N.A., 1969. New representatives of Eocene radiolarians in Azerbaidzhan. In Vialov, O.S. (Ed.), Fossil and Recent Radiolarians: Lvov (Izd. Lvovskogo Univ.), 94-101.

McGowran, B., Moss, G., and Beecroft, A., 1992. Late Eocene and early Oligocene in southern Australia: local neritic signals of global and oceanic changes. In Prothero, D.R., and Berggren, W.A. (Eds.), Eocene-Oligocene Climatic and Biotic Evolution: Princeton (Princeton Univ. Press), 178-201.

Miller, K.G., and Fairbanks, R.G., 1983. Evidence for Oligocene-middle Miocene abyssal circulation changes in the western North Atlantic. Nature, 306:250-253.

Miller, K.G., Fairbanks, R.G., and Mountain, G.S., 1987. Tertiary oxygen isotope synthesis, sea-level history, and continental margin erosion. Paleoceanography, 2:1-19.

Miller, K.G., Gradstein, F.M., and Berggren, W.A., 1982. Late Cretaceous to early Tertiary agglutinated benthic foraminifera in the Labrador Sea. Micropaleontology, 28:1-30.

Miller, K.G., and Tucholke, B.E., 1983. Development of Cenozoic abyssal circulation south of the Greenland-Scotland Ridge. In Bott, M., Saxov, S., Talwani, M., and Thiede, J. (Eds.), Structure and Development of the Greenland-Scotland Ridge: New Methods and Concepts: New York (Plenum), 549-590.

Moore, T.C., Jr., van Andel, T.H., Sancetta, C., and Pisias, N., 1978. Cenozoic hiatuses in the pelagic sediments. Micropaleontology, 24:113-138.

Müller, C., 1976. Tertiary and Quaternary calcareous nannoplankton in the Norwegian-Greenland Sea, DSDP, Leg 38. In Talwani, M., Udintsev, G., et al., Init. Repts. DSDP, 38: Washington (U.S. Govt. Printing Office), 823-841.

Mullineaux, L.S., and Westberg-Smith, M.J., 1986. Radiolarians as paleoceanographic indicators in the Miocene Monterey Formation, upper Newport Bay, California. Micropaleontology, 32:48-70.

Myhre, A.M., and Eldholm, O., 1988. The western Svalbard margin $\left(74^{\circ}-\right.$ $80^{\circ}$ N). Mar. Pet. Geol., 5:134-156.

Myhre, A.M., Eldholm, O., Faleide, J.I., Skogseid, J., Gudlaugsson, S.T., Planke, S., Stuevold, L.M., and Vaagnes, E., 1992. Norway-Svalbard continental margin: structural and stratigraphical styles. In Poag, C.W., and de Graciansky, P.C. (Eds.), Geologic Evolution of Atlantic Continental Rises: New York (Van Nostrand Reinhold), 157-185.

Myhre, A.M., Eldholm, O., and Sundvor, E., 1982. The margin between Senja and Spitsbergen fracture zones: implication from plate tectonics. Tectonophysics, 89:33-50.

Myhre, A.M., Thiede, J., Firth, J.V., et al., 1995. Proc. ODP, Init. Repts., 151: College Station, TX (Ocean Drilling Program).

Nigrini, C., 1974. Cenozoic Radiolaria from the Arabian Sea, DSDP Leg 23. In Davies, T.A., Luyendyk, B.P., et al., Init. Repts. DSDP, 26: Washington (U.S. Govt. Printing Office), 1051-1121.

, 1977. Tropical Cenozoic Artostrobiidae (Radiolaria). Micropaleontology, 23:241-269.

Nigrini, C., and Lombari, G., 1984. A Guide to Miocene Radiolaria. Spec. Publ. Cushman Found. Foraminiferal Res., 22. 
Petrushevskaya, M., 1979. Evolution of Radiolaria in the Norwegian-Greenland basin. In Strelkov, A.A., and Petrushevskaya, M.G. (Eds.), The History of the Microplankton of the Norwegian Sea (on the Deep Sea Drilling Materials). Explorations of the Fauna of the Sea, Acad. Sci. USSR, Zool. Inst., 23:86-157.

Petrushevskaya, M.G., 1971. Radiolyarii Nassellaria v planktone Mirovogo Okeana (Radiolarians of the Ocean). Issled. Fauny Morei, 9:1-294.

-, 1975. Cenozoic radiolarians of the Antarctic, Leg 29, DSDP. In Kennett, J.P., Houtz, R.E., et al., Init. Repts. DSDP, 29: Washington (U.S. Govt. Printing Office), 541-675.

Petrushevskaya, M.G., and Kozlova, G.E., 1972. Radiolaria, Leg 14, Deep Sea Drilling Project. In Hayes, D.E., Pimm, A.C., et al., Init. Repts. DSDP, 14: Washington (U.S. Govt. Printing Office), 495-648.

Popofsky, A., 1908. Die Radiolarien der Antarktis (mit Ausnahme der Tripyleen) (Radiolaria from the Antarctic (Tripylida excepted)). Disch. Sudpolar-Exped,, 1901-1903, 14 (Zool, vol. 6):217-416.

Premoli-Silva, I., Coccioni, R., and Montanari, A. (Eds.), 1988. The Eocene/ Oligocene Boundary in the March-Umbria Basin (Italy). Spec. Publ. Int. Subcommission on Paleogene Stratigr., Eocene/Oligocene Boundary Meeting, Ancona, 1987.

Prothero, D.R., 1994. The Eocene-Oligocene Transition: Paradise Lost: New York (Columbia Univ. Press).

Riech, V., and von Rad, U., 1979. Silica diagenesis in the Atlantic Ocean: diagenetic potential and transformations. In Talwani, M., et al. (Eds.), $M$. Ewing Ser., 3:315-340.

Riedel, W.R., 1958. Radiolaria in Antarctic sediments. Rep. B.A.N.Z. Antarct. Res. Exped., Ser. B, 6:217-255.

Riedel, W.R., and Sanfilippo, A., 1986. Radiolarian events and the EoceneOligocene boundary. In Pomerol, C., and Premoli-Silva, I. (Eds.), Terminal Eocene Events: Amsterdam (Elsevier), 253-257.

Roberts, D.G., 1975. Marine geology of the Rockall Plateau and Trough. Philos. Trans. R. Soc. London, 278:447-509.

Ruddiman, W.F., 1972. Sediment redistribution on the Reykjanes Ridge: seismic evidence. Geol. Soc. Am. Bull., 83:2039-2062.

Rüst, D., 1885. Beitrage zur Kenntniss der fossilen Radiolarien aus Gesteinen des Jura. Palaeontographica, 31:269-321.

Saito, T., Burckle, L.H., and Horn, D.R., 1967. Paleocene core from the Norwegian basin. Nature, 216:357-359.

Sanfilippo, A., 1990. Origin of the subgenera Cyclampterium, Paralampterium, and Sciadiopeplus from Lophocyrtis (Lophocyrtis) (Radiolaria, Theoperidae). Mar. Micropaleontol, 15:287-312.

Sanfilippo, A., and Riedel, W.R., 1973. Cenozoic Radiolaria (exclusive of theoperids, artostrobiids and amphipyndacids) from the Gulf of Mexico, Deep Sea Drilling Project Leg 10. In Worzel, J.L., Bryant, W., et al., Init. Repts. DSDP, 10: Washington (U.S. Govt. Printing Office), 475-611.

Sanfilippo, A., Westberg-Smith, M.J., and Riedel, W.R., 1985. Cenozoic radiolaria. In Bolli, H.M., Saunders, J.B., and Perch-Nielsen, K. (Eds.), Plankton Stratigraphy: Cambridge (Cambridge Univ. Press), 631-712.

Schrader, H.-J., and Fenner, J., 1976. Norwegian Sea Cenozoic diatom biostratigraphy and taxonomy. In Talwani, M., Udintsev, G., et al., Init. Repts. DSDP, 38: Washington (U.S. Govt. Printing Office), 921-1099.
Srivastava, S.P., Arthur, M., Clement, B., et al., 1987. Proc. ODP, Init. Repts., 105: College Station, TX (Ocean Drilling Program).

Stöhr, E., 1880. Die Radiolarienfauna der Tripoli von Grotte, Provinz Girgenti in Sicilien (The radiolarian fauna of the Tripoli of Grotte, Girgenti Province, Sicily). Paleontographica, 26:69-124.

Sundvor, E., and Eldholm, O., 1979. The western and northern margin off Svalbard. Tectonophysics, 59:239-250.

Takemura, A., 1992. Radiolarian Paleogene biostratigraphy in the southern Indian Ocean, Leg 120. In Wise, S.W., Jr., Shlich, R., et al., Proc. ODP, Sci. Results, 120: College Station, TX (Ocean Drilling Program), 735756.

Talwani, M., and Eldholm, O., 1977. Evolution of the Norwegian-Greenland Sea. Geol. Soc. Am. Bull., 88:969-999.

Talwani, M., Udintsev, G., et al., 1976. Init. Repts. DSDP, 38: Washington (U.S. Govt. Printing Office).

Thiede, J., Eldholm, O., and Taylor, E., 1989. Variability of Cenozoic Norwegian-Greenland Sea paleoceanography and Northern Hemisphere paleoclimate: synthesis of paleoenvironmental studies of ODP Leg 104, Vøring Plateau, Norwegian continental margin. In Eldholm, O., Thiede, J., Taylor, E., et al., Proc. ODP, Sci. Results, 104: College Station, TX (Ocean Drilling Program), 1067-1118.

Thiede, J., Pfirman, S., Schenke, H.-W., and Reil, W., 1990b. Bathymetry of Molloy Deep: Fram Strait between Svalbard and Greenland. Mar. Geophys. Res., 12:197-214.

Thomas, E., 1992. Middle Eocene-late Oligocene bathyal benthic foraminifera (Weddell Sea): faunal changes and implications for ocean circulation. In Prothero, D.R., and Berggren, W.A. (Eds.), Eocene-Oligocene Climatic and Biotic Evolution: Princeton (Princeton Univ. Press), 245271.

Vogt, P.R., 1986. Seafloor topography, sediments, and paleoenvironments. In Hurdle, B.G. (Ed.), The Nordic Seas: New York (Springer-Verlag), 237412.

Westberg-Smith, M.J., and Riedel, W.R., 1984. Radiolarians from the western margin of the Rockall Plateau: Deep Sea Drilling Project Leg 81. In Roberts, D.G., Schnitker, D., et al., Init. Repts. DSDP, 81: Washington (U.S. Govt. Printing Office), 479-501.

Wold, C.N., Hay, W.W., Dullo, W.-C., Wolf, T.C.W., and Bruns, P., 1993. Oligozäne Paläo-ozeanographie des Grönland-Schottland-Rückens. Geowiss., 11:353-359.

Zachos, J.C., Lohmann, K.C., Walker, J.C.G., and Wise, S.W., Jr., 1993. Abrupt climate change and transient climates during the Paleogene: a marine perspective. J. Geol., 101:191-213.

Date of initial receipt: 30 June 1995

Date of acceptance: 6 December 1995

Ms 151SR-103 


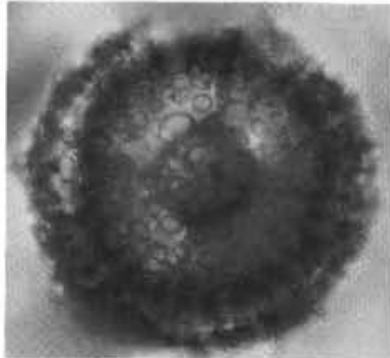

1

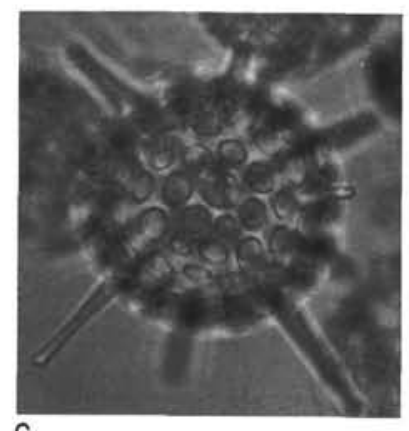

6

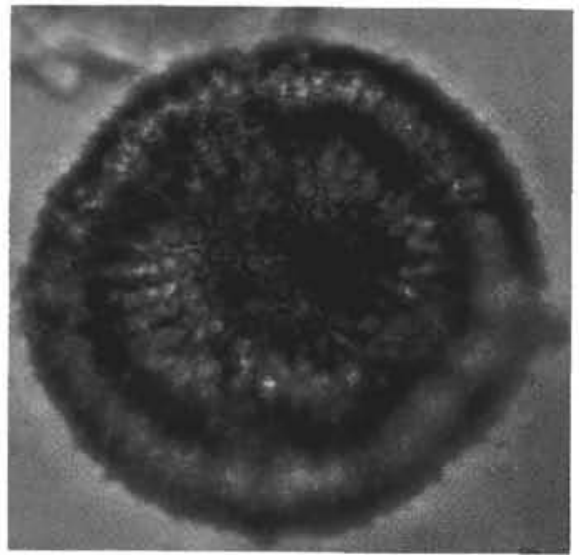

10

2

7
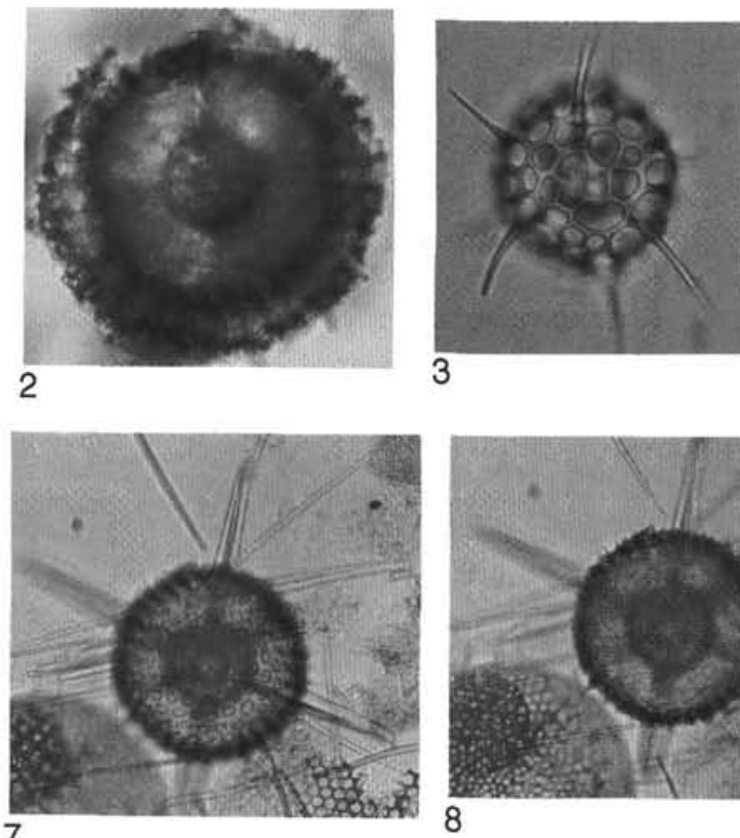

3

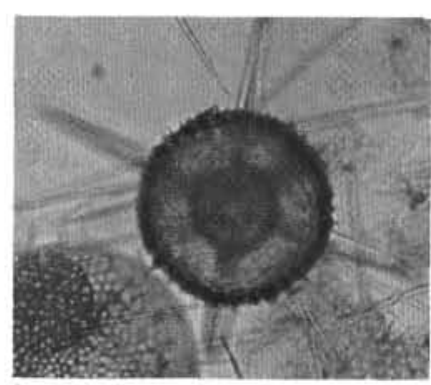

8

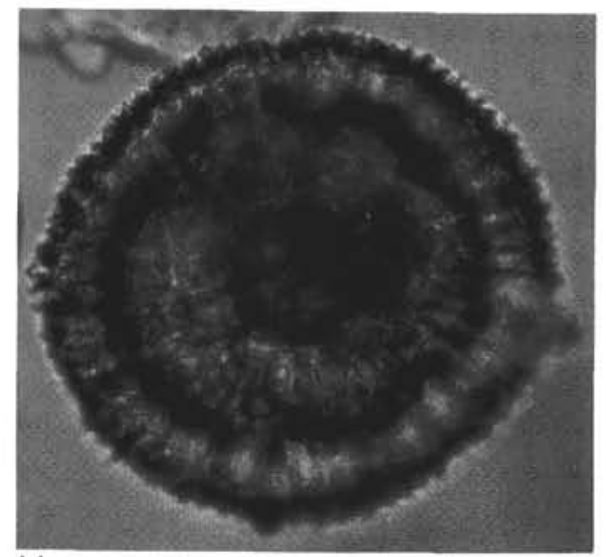

11
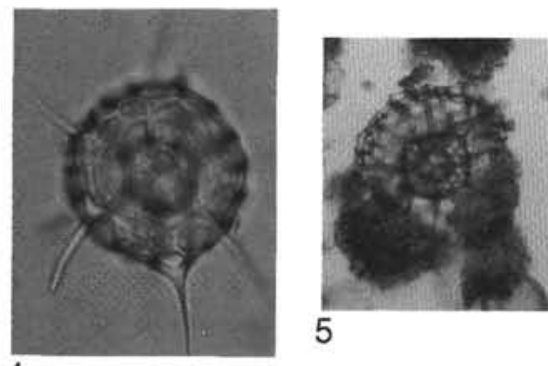

5
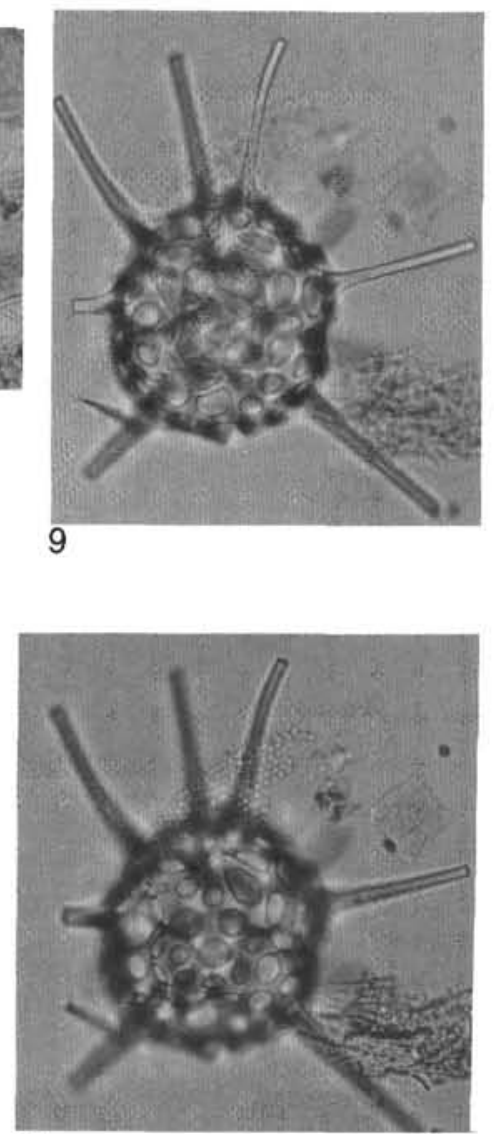

12

Plate 1. 1, 2. Actinomma sp. cf. A. holtedahli, 151-913B-24R-5, 37-41 cm; 2-S47/4 (England Finder position), 50×, 50×. 3, 4. Actinomma(?) sp. B, 151-908A$32 \mathrm{X}-6,126-128 \mathrm{~cm} ; 2-\mathrm{N} 20 / 3,25 \times, 25 \times .5$. Actinomma sp. C, 151-908A-23X-3, 117-119 cm; 2-L29/3, 10×. 6. Actinomma sp. A, 151-913B-26R-2, 15-17 cm; 1-F40/3, 100×. 7, 8. Hexacontium hexactis, 151-913B-25R-6, 46-48 cm; 1-S42/2, 50×, 50×. 9, 12. Actinomma(?) sp. B, 151-913B-25R-7, 1-O10/3, 100×, $100 \times .10,11$. Heterosestrum sexispinatum rotundum, 151-913B-27R-5, 5-7 cm; 1-W40/1, 50X, 50X. 


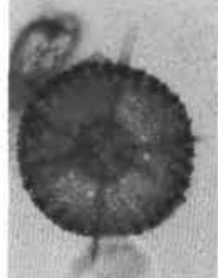

1

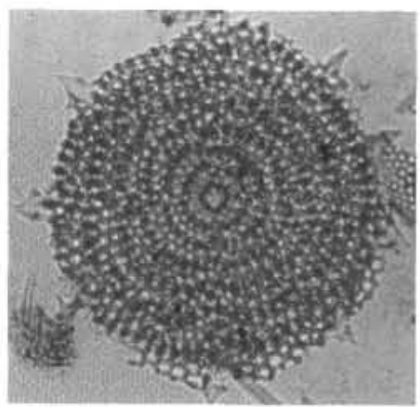

7

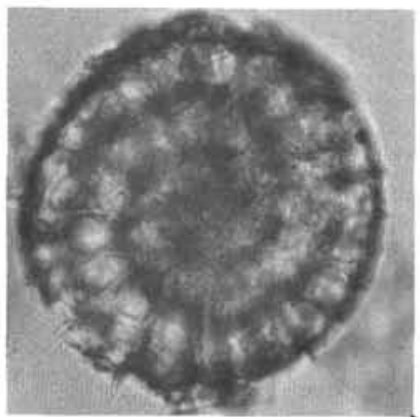

12

2

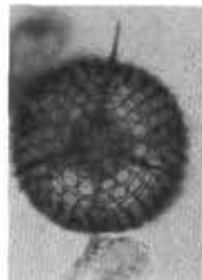

3

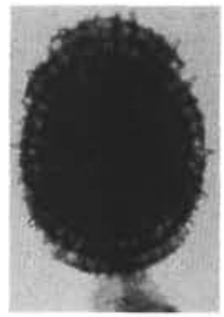

8

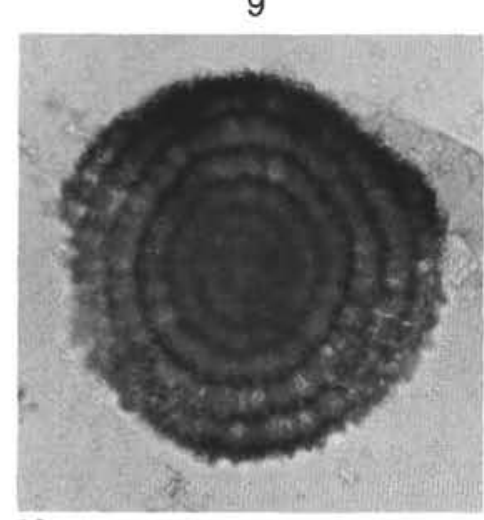

13

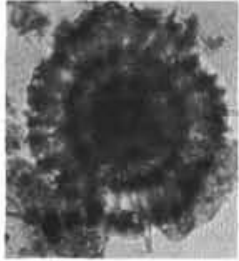

3

4

9
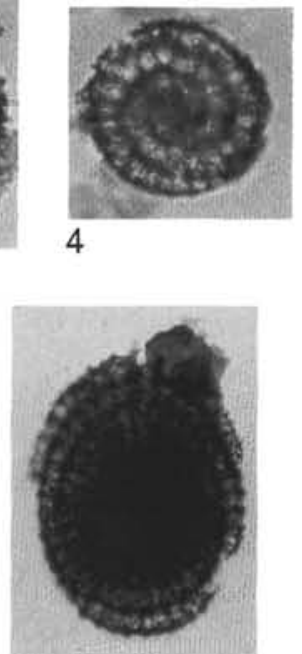$$
8
$$

16

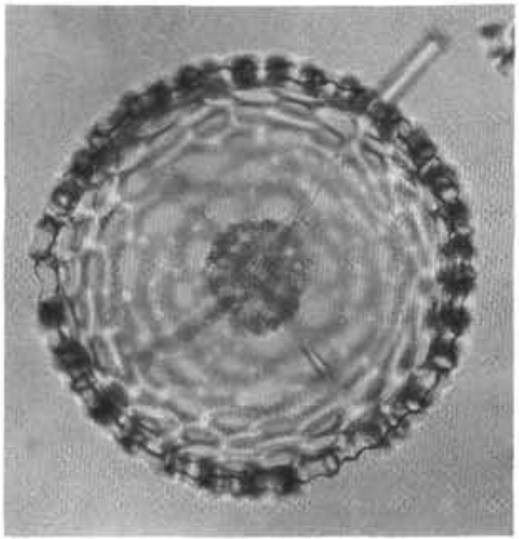

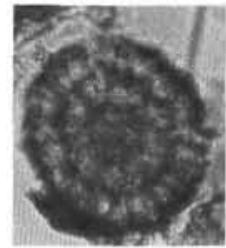

5

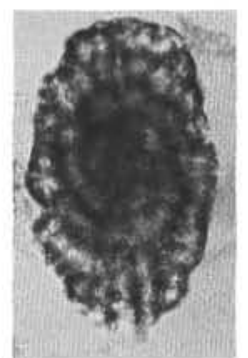

10

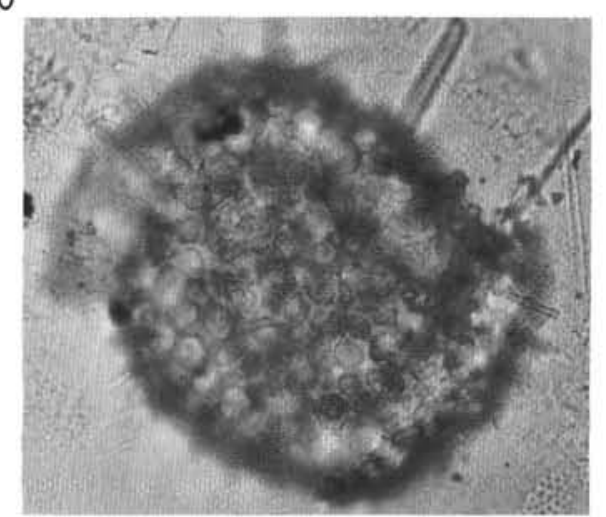

14

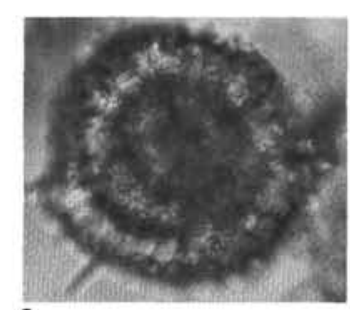

6

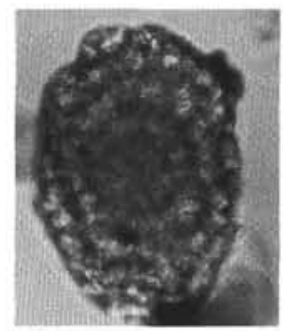

11

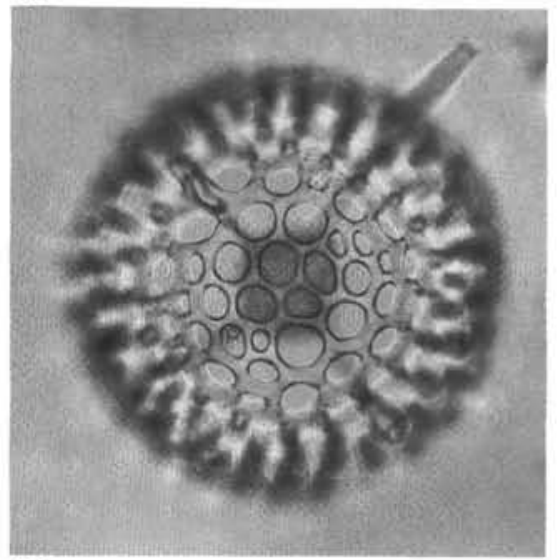

15

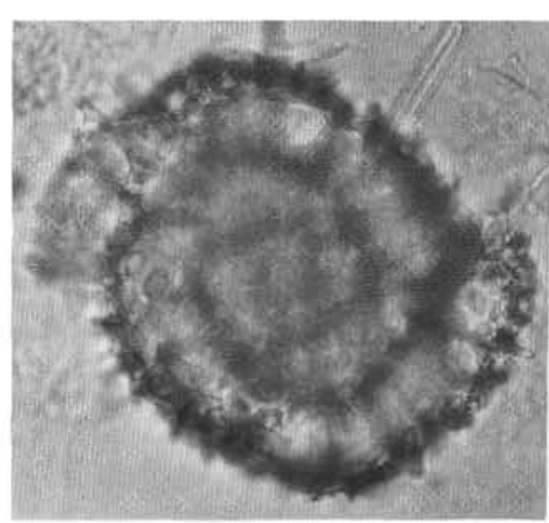

17

Plate 2. 1, 2. Hexacontium sp., 151-908A-22X-1, 94-96 cm; 2-R56/C (England Finder position), 10×, 10X. 3. Lithelius sp. aff. L. nautiloides, 151-908A-20X-5, 70-72 cm; 1-S35/C, 50×. 4-6. Lithelid gen. et spp. indet.: 4, 5, 151-913B-25R-4, 85-87 cm; 6, 151-913B-26R-1, 81-83 cm; all 50×. 7. Porodiscus(?) sp., 151913B-26R-2, 15-17 cm; 1-B35/1, 50X. 8. Prunopyle sp. aff. P. haysi, 151-908A-28X-5, 92-95 cm; 2-J36/C, 10X. 9. P. sp. aff. P. haysi, 151-908A-22X-1, 94-96 cm; 2-P63/C, 10×. 10, 11. Spongurus(?) spp. A group, 151-913B-26R-1, 81-83 cm; 1-X47/1, 50×, 50×. 12. Lithelid gen. et sp. indet., 151-913B-25R-4, 85-87 cm, 100×. 13. Prunopyle(?) sp., 151-913B-27R-5, 71-74 cm; 1-J12/4, 100×. 14, 17. Lithelid gen. et sp. indet., 151-913B-27R-1, 91-93 cm; 1-R29/C, 100×, 100×. 15, 16. Actinomma sp. D, 151-913B-24R-4, 69-71 cm; 3-G31/C, 100×, 100×. 


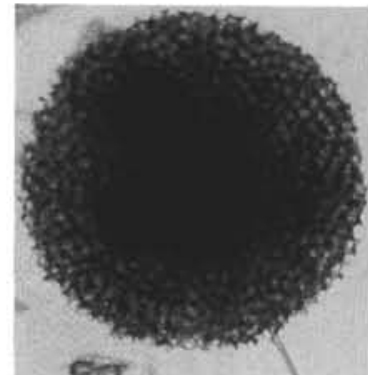

1

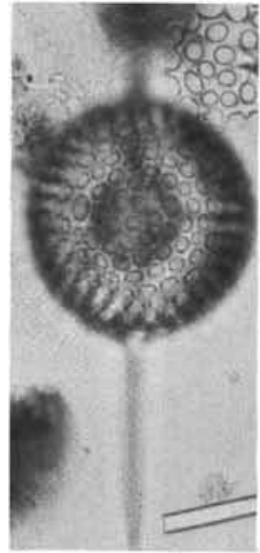

6

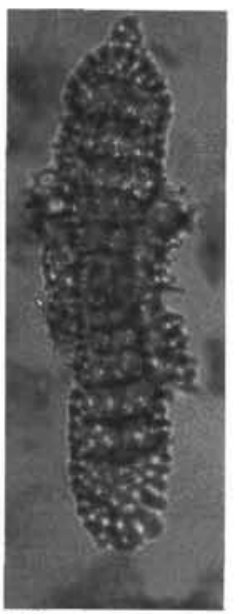

14

15

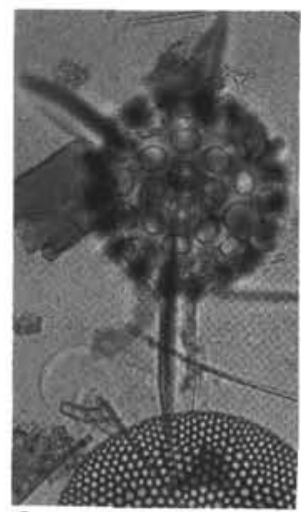

2
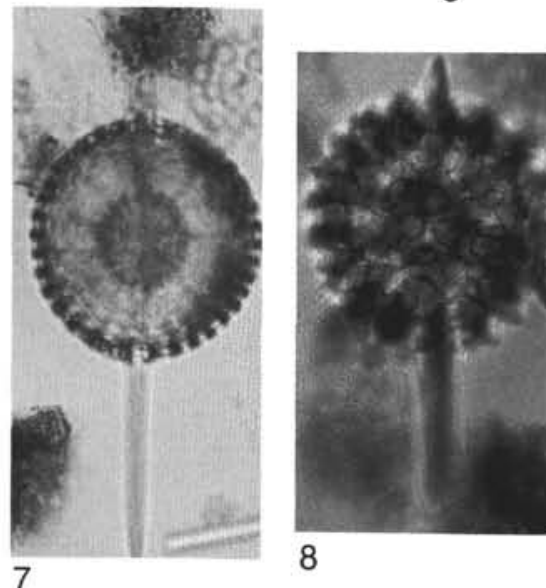

8

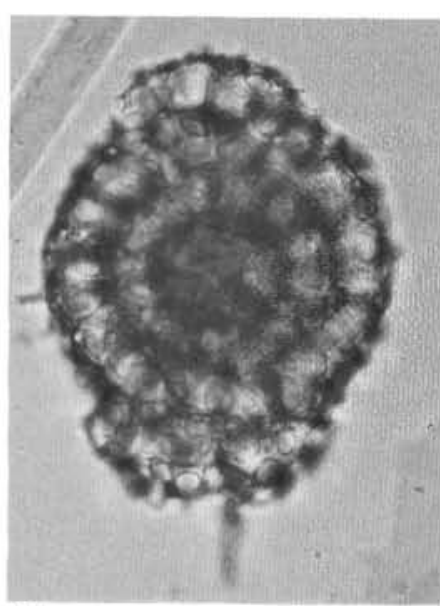

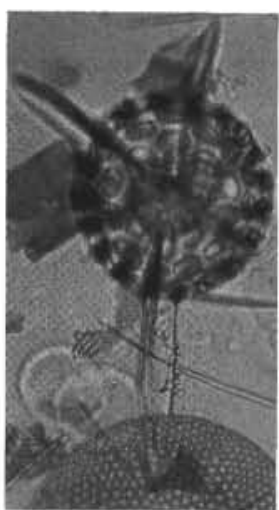

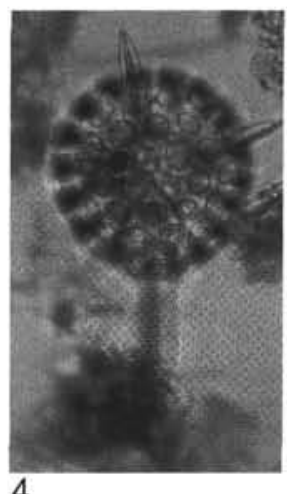

4

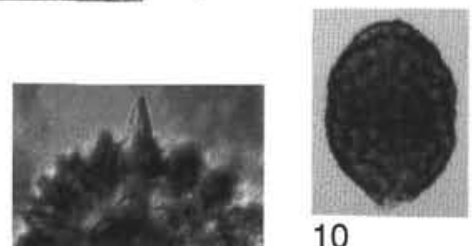

10

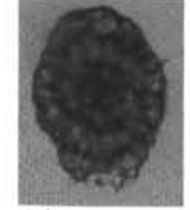

11

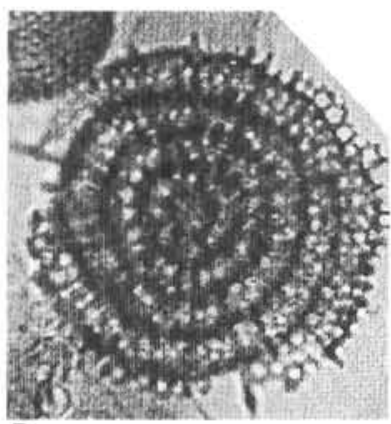

5
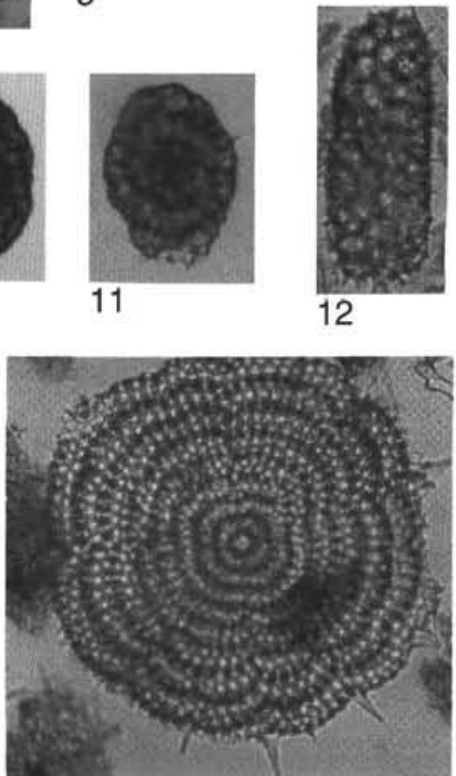

13

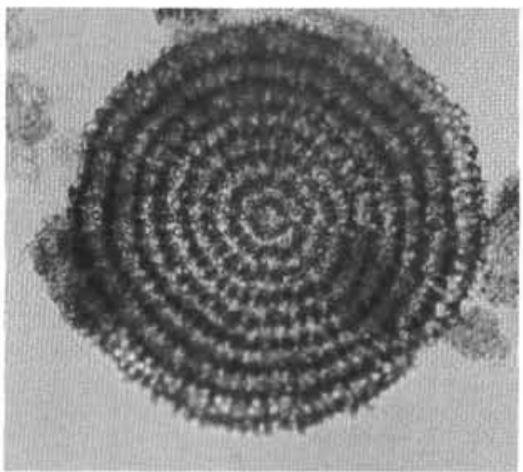

17

Plate 3. 1. Spongotrochus america, 2, 3. Stylatractus $\mathrm{sp}$. A, 151-913B-26R-2, 118-121 cm; 50×, 50×. 4. Stylatractus sp. A, 151-913B-26R-1, 81-83 cm; 1-E26/ C, 50×. 5. Stylodictya aculeata, 151-913B-24R-1, 140-142 cm; 1-Q23/C, 160×. 6, 7. Sphaerostylus cristatus group, 151-913B-27R-4, 34-36 cm; 2-M44/C, $50 \times, 50 \times .8$, 9. Stylatractus sp. B, 151-913B-26R-1, 81-83 cm; 2-M24/2, 50×, 50×. 10. Spongurus(?) spp. B group, 151-908A-21X-1, 119-121 cm; 10×. 11. Spongurus(?) spp. B group, 151-908A-26X-3, 99-100 cm; 1-J11/C, 10X. 12. Spongurus spp. C group, 151-913B-26R-2, 118-121 cm; 1-G38/2, 50X. 13. Stylodictya targaeformis, 151-913B-24R-4, 69-71 cm; 1-N25/C, 50×. 14. Spongocore sp., 151-913B-24R-2, 120-122 cm; 1-M27/C, 100X. 15. Spongurus(?) spp. A group, 151-913B-26R-1, 81-83 cm; 1-X47/1, 100×. 16. Spongurus spp. C group, 151-913B-26R-3, 10-12 cm; 1-X27/1, 100×. 17. Stylodictya validispina, 151-913B-19W-4, 139-142 cm; 1-P32/2, 50X. 


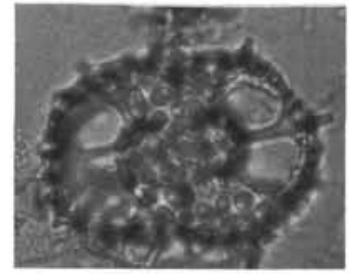

1

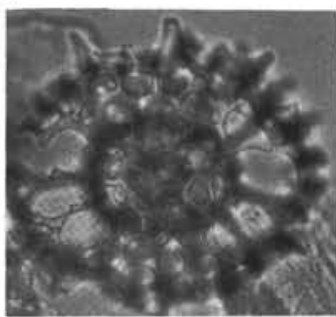

7

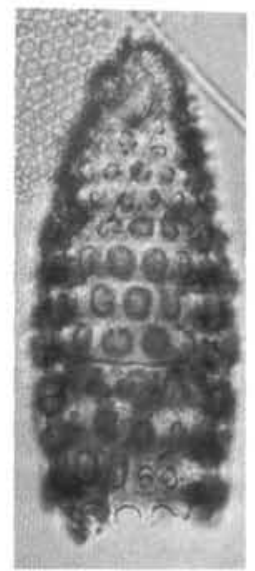

12

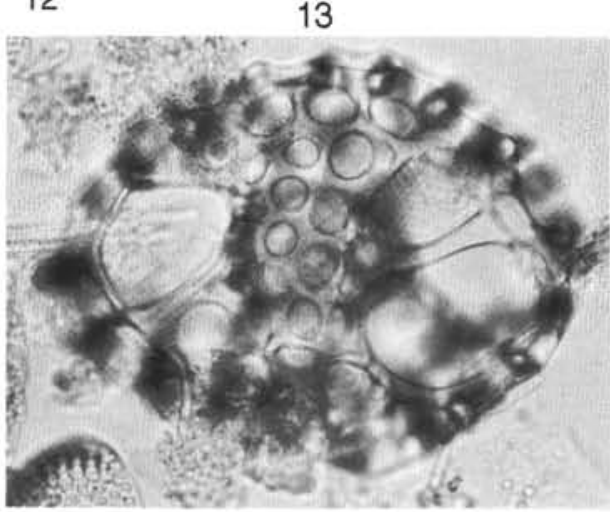

17

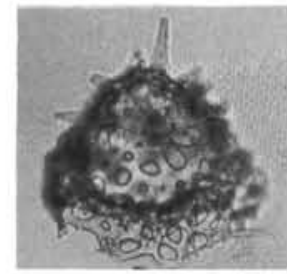

2

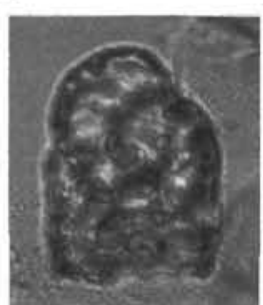

8

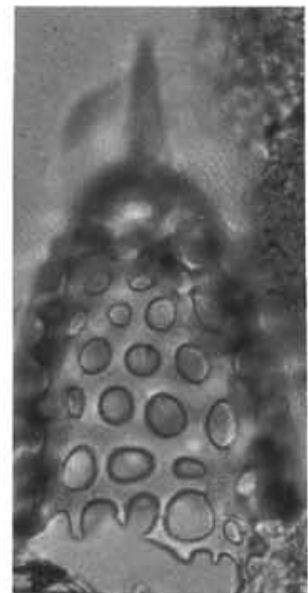

13

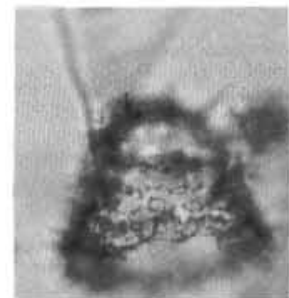

3

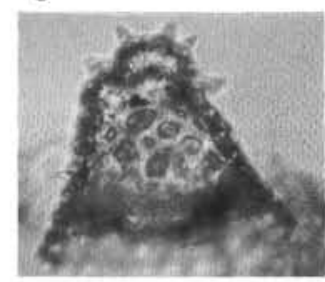

9

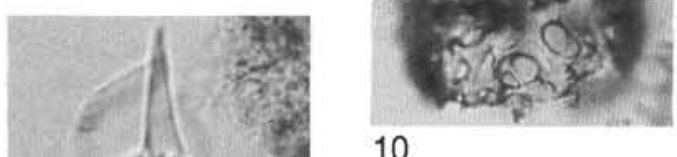

10

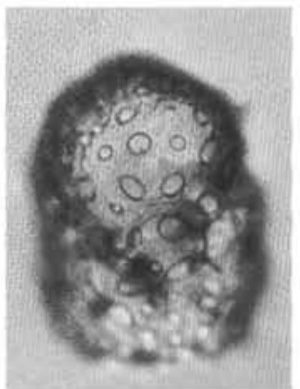

15

14

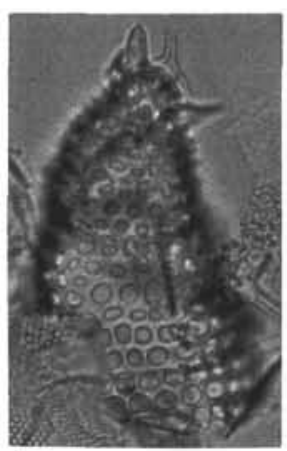

18

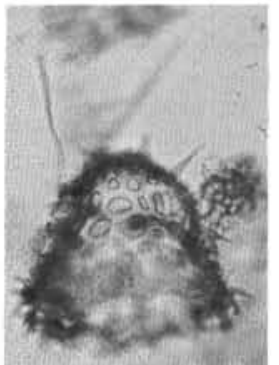

4
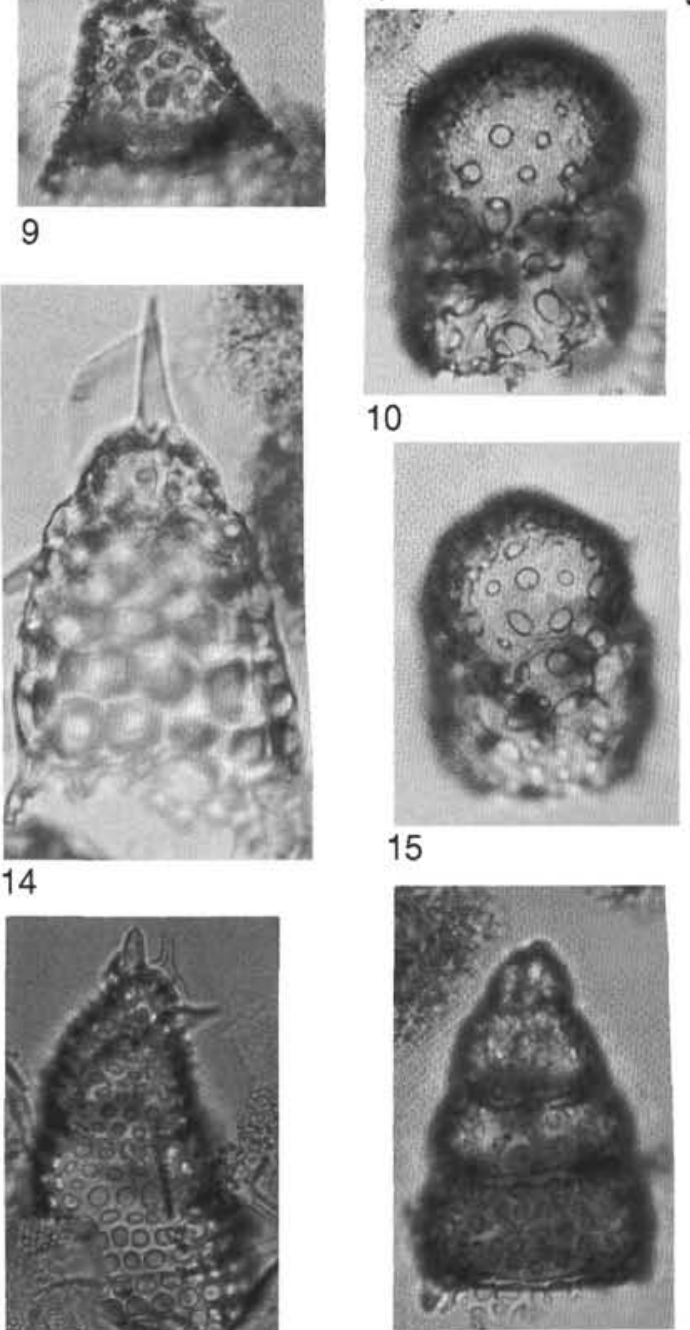

19

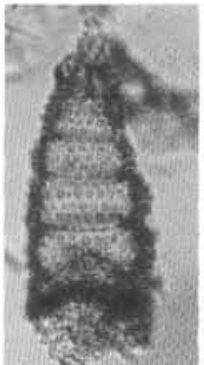

5

5
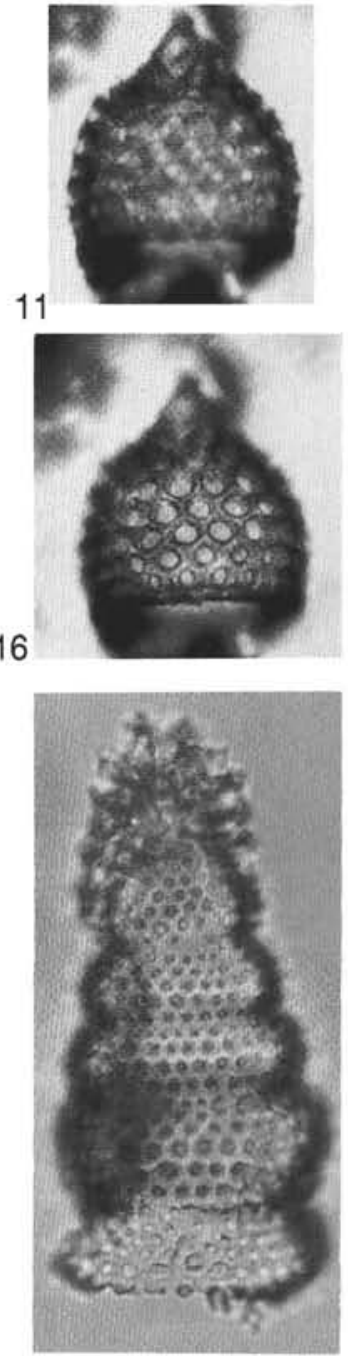

20

Plate 4. 1. Tetrapyle(?) sp. A, 151-913B-27R-2, 72-74 cm; 1-L34/2 (England Finder position), 100×. 2. Botryopera(?) pseudoantarctissa, 151-913B-25R-7, 5-7 cm; 1-C19/C, 100×. 3, 4. Botryopera(?) pseudoantarctissa, 151-913B-26R-1, 81-83 cm; 1-H33/1, 100×, 100×. 5. Botryostrobus joides, 151-913B-25R4, 85-87 cm; 1-V31/C, 50×. 6. B. joides, 151-913B-24R-1, 140-142 cm; 2-L23/2, 50×. 7. Tetrapyle(?) sp. A, 151-913B-24R-3, 108-110 cm; 1-C22/C, 100X. 8. Botryocampe sp., 151-913B-26R-2, 15-17 cm; 1-J26/4, 100×. 9. Ceratocyrtis sp. cf. C. cucullaris, 151-913B-26R-1, 81-83 cm; 2-E36/2, 50X. 10. Antarctissa robusta, 151-913B-19W-4, 139-142 cm; 1-H26/C, 100×. 11, 16. Calocyclas talwanii, 151-913B-32R-CC; 25×, 25×. 12. Artostrobus quadriporus, 151913B-25R-6, 46-48 cm; 2-U31/C, 100×. 13, 14. Artostrobus(?) sp. 151-913B-26R-3, 10-12 cm; 1-K26/C, 100×, 100X. 15. Antarctissa robusta, 151-913B19W-4, 139-142 cm; 1-F22/C, 100×. 17. Tetrapyle(?) sp. B, 151-908A-23X-4, 120-122 cm; 2-O31/2, 100×. 18. Botryostrobus sp. aff. B. kerguelensis, 151913B-25R-1, 26-28 cm; 2-H40/2, 50×. 19. Amphipternis sp., 151-908A-20X-5, 70-72 cm; 100×. 20. B. joides, 151-913B-27R-4, 34-36 cm; 1-H26/C, 100X. 


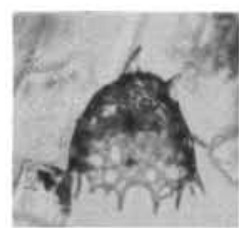

1

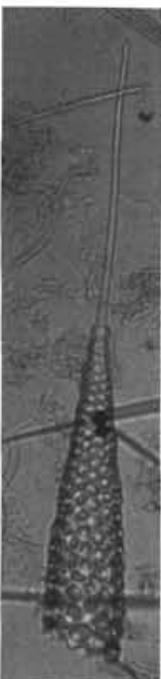

7

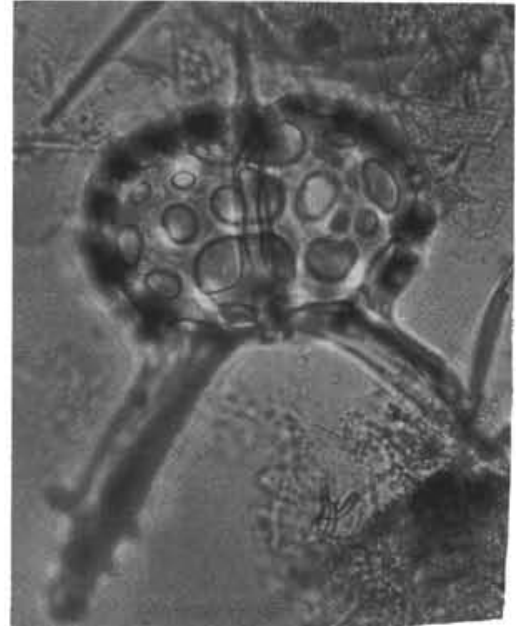

14

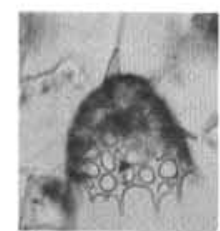

2

8

9
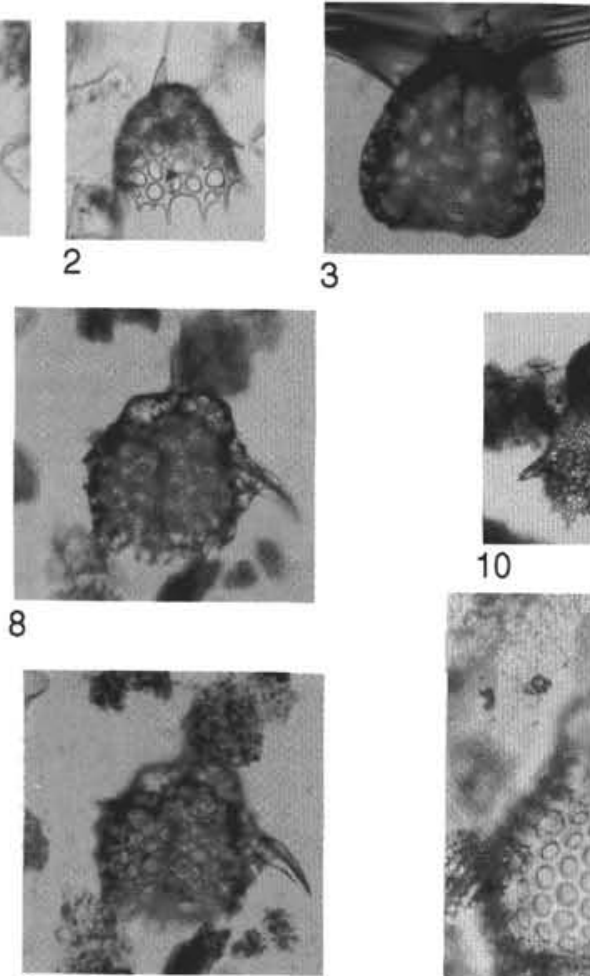

3

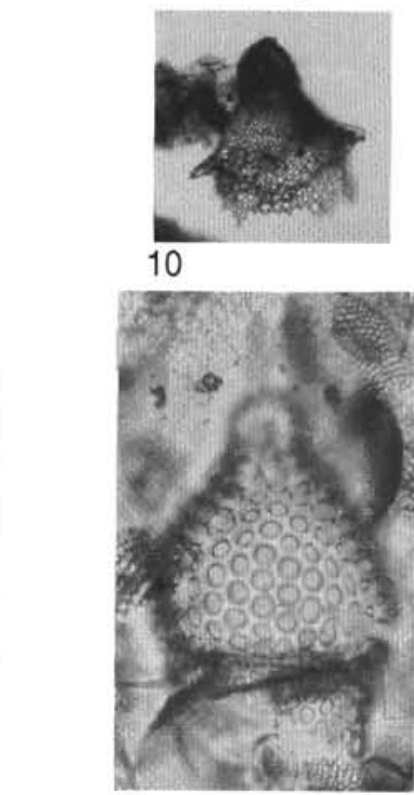

11

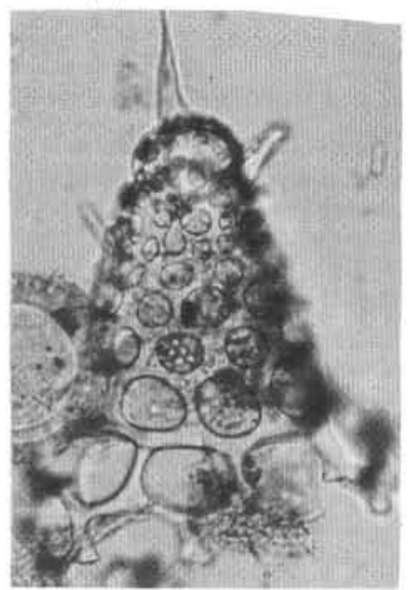

15

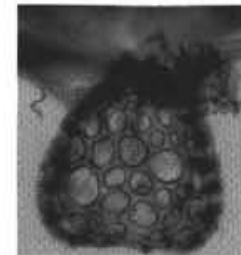

4

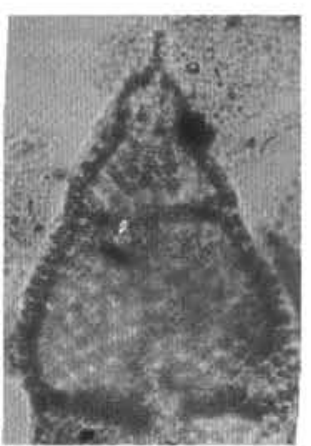

5

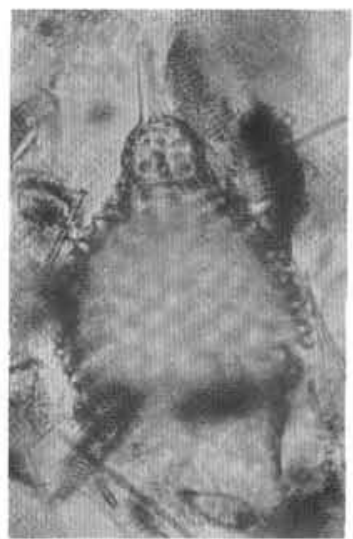

12

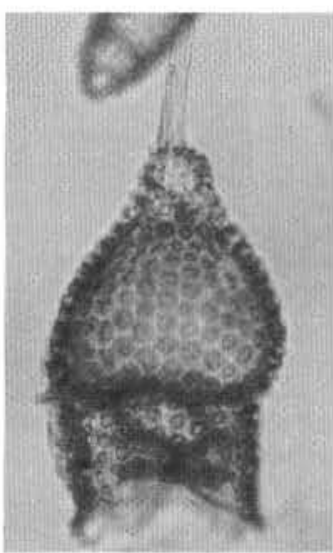

16

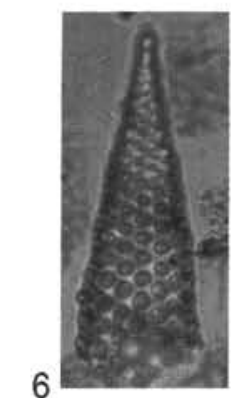

13
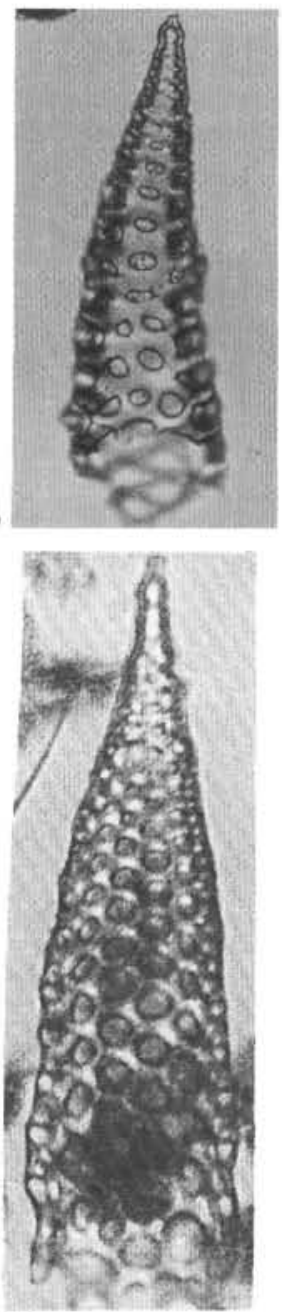

17

Plate 5. 1, 2. Ceratocyrtis stigi, 151-908A-22X-1, 94-96 cm; 1-R51/C (England Finder position), 10×, 10X. 3, 4. Ceratocyrtis mashae, 151-908A-30X-2, 113$115 \mathrm{~cm} ; 2-C 42 / 1,10 \times, 10 \times .5$. Eucyrtidium sp., 151-913B-32R-3, 70-74 cm; 1-S31/2, 50X. 6. Cornutella sp. aff. C. californica, 151-913B-26R-2, 15-17 cm; 1E14/2, 50×. 7. Cornutella sp., 151-913B-27R-3, 25-27 cm; 2-E46/2, 50×. 8, 9. Lithomelissa sp., 151-908A-30X-5, 113-117 cm; 3-F38/4, 10×, 10X. 10. Lipmanella sp., 151-908A-31X-CC; 10×. 11, 12. Lophocyrtis andriashevi, 151-913B-25R-7, 5-7 cm; 1-M33/1, 50×, 50×. 13. Cornutella clathrata, 151-913B19W-4, 139-142 cm; 1-Q24/2, 100×. 14. Corythospyris palmipodiscus, 151-913B-25R-7, 5-7 cm; 2-H28/4, 100×. 15. Cycladophora sp. cf. C. conica, 151908A-33X-1, 128-130 cm; 1-J23/C, 100X. 16. Lophocyrtis andriashevi, 151-913B-24R-5, 37-41 cm; 2-P47/4, 50×. 17. Cornutella profunda group, 151-913B$24 \mathrm{R}-4,69-71 \mathrm{~cm} ; 3-\mathrm{J} 18 / 2,160 \times$. 


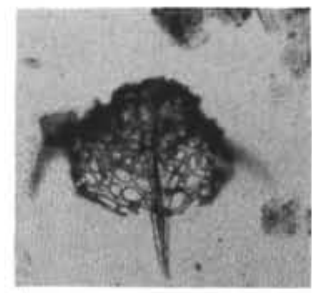

1

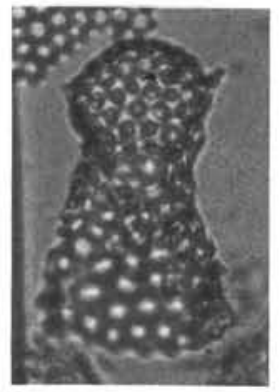

6

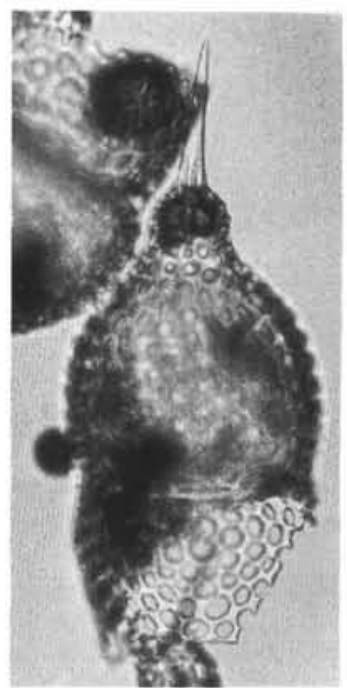

12

7

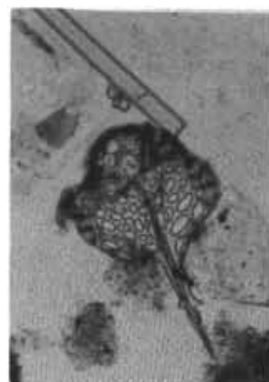

2
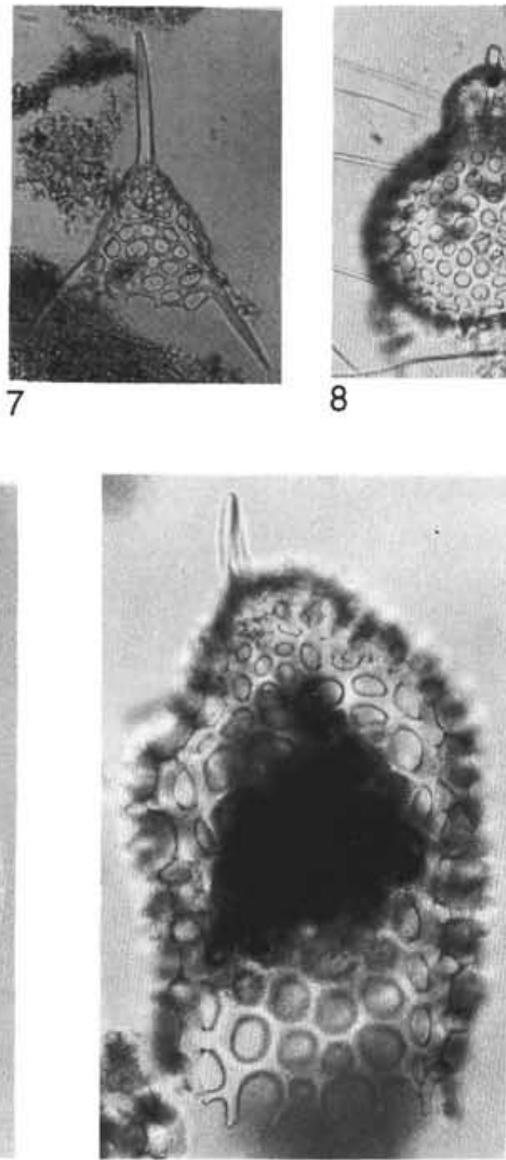

13

8
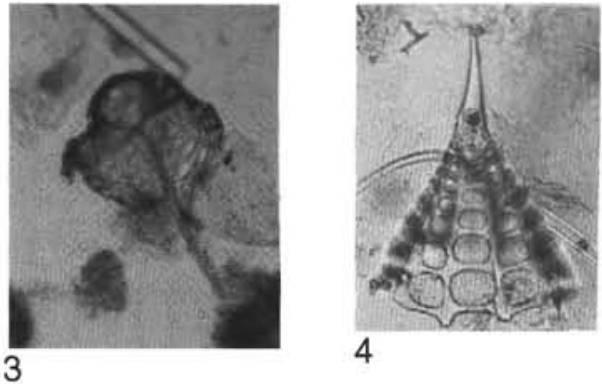

4
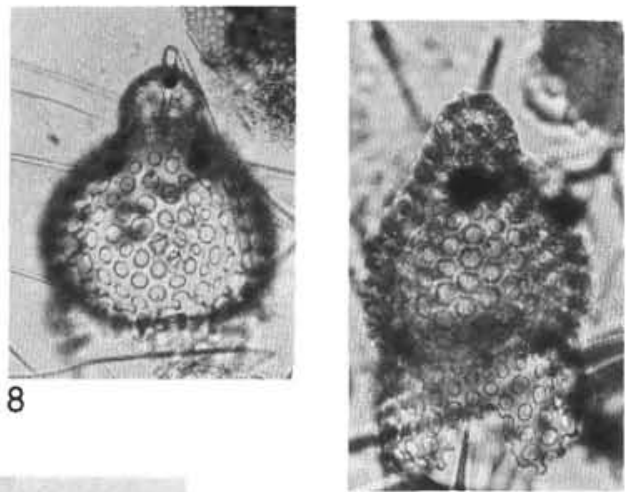

9

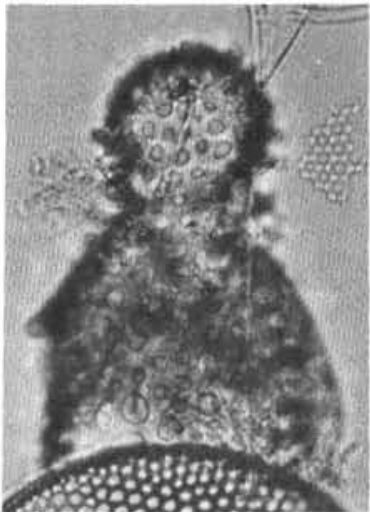

14

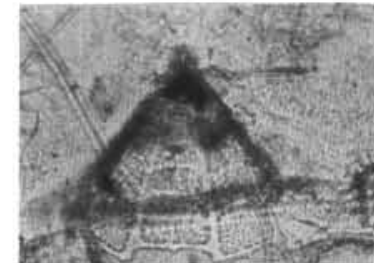

5

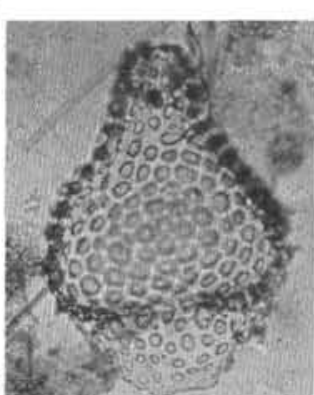

10

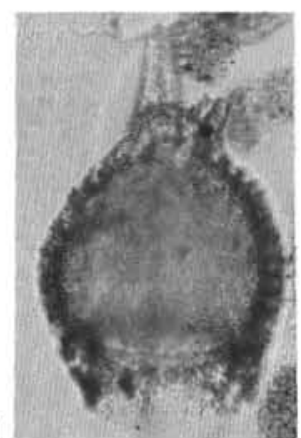

11

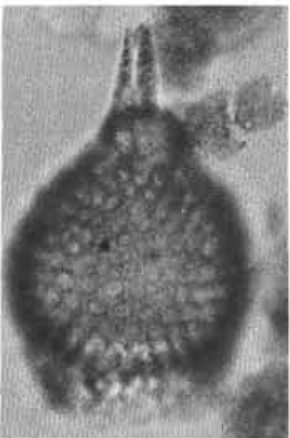

15

Plate 6. 1. ?Pseudodictyophimus horrida, 151-908A-32X-4, 131-133 cm; 1-W33/1 (England Finder position), 10X. 2, 3. Pseudodictyophimus platycephalus, 151-908A-26X-2, 82-84 cm; 3-H44/1, 100×, 100×. 4. Peripyramis magnifica, 151-913B-27R-1, 91-93 cm; 1-S29/C, 50×. 5. Peripyramis sp. aff. P. magnifica, 151-913B-27R-1, 91-93 cm; 2-M32/2, 50×. 6. Lophophaena clevei, 151-913B-27R-3, 71-73 cm; 1-O23/1, 100×. 7. Pseudodictyophimus sp. A, 151-913B24R-4, 69-71 cm; 3-U31/4, 50×. 8. Lophocyrtis semipolita group, 151-913B-26R-1, 90-93 cm; 1-J42/C, 50X. 9. L. semipolita group, 151-913B-26R-2, 118$121 \mathrm{~cm} ; 1-\mathrm{M} 32 / \mathrm{C}, 50 \times .10$. Lophocyrtis litos group, 151-913B-27R-1, 91-93 cm; 1-R30/2, 50X. 11, 15. Lophocyrtis norvegiensis, 151-913B-32R-2, 65-68 cm; 1-M30/C, 50×, 50×. 12. Lophocyrtis sp., 151-913B-25R-CC; 50×. 13. Nassellarian gen. et sp. indet., 151-913B-24R-4, 69-71 cm; 3-O23/C, 50×. 14. Lophophaena macrencephala, 151-913B-27R-3, 25-27 cm; 2-V44/2, 100X. 


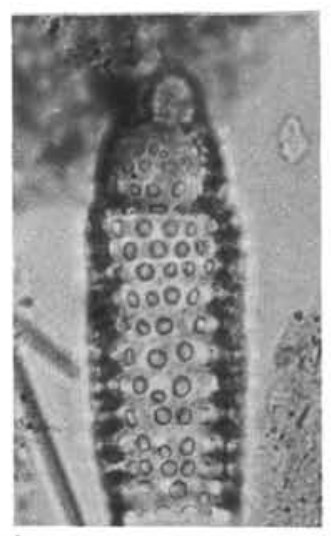

1

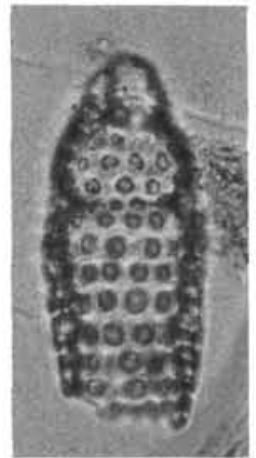

5

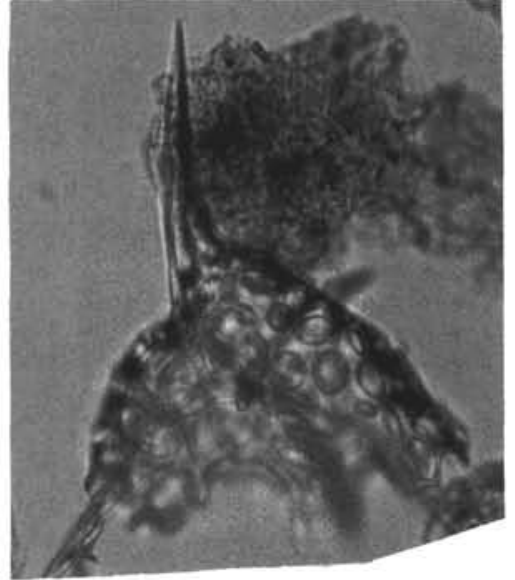

9

2

6
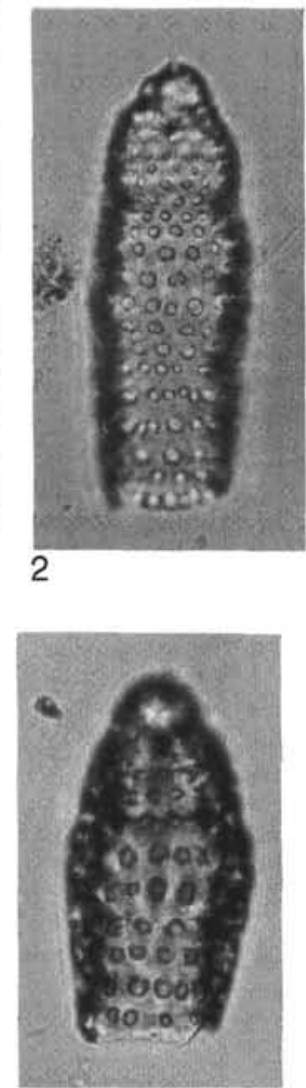

7

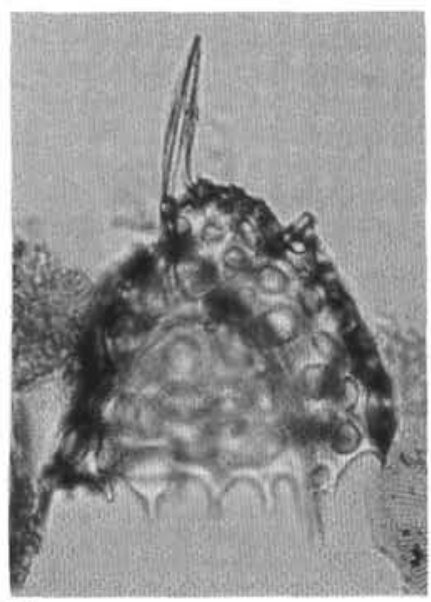

10

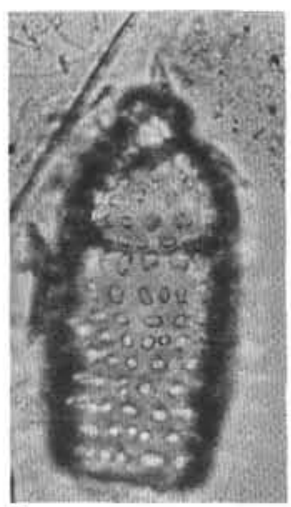

3
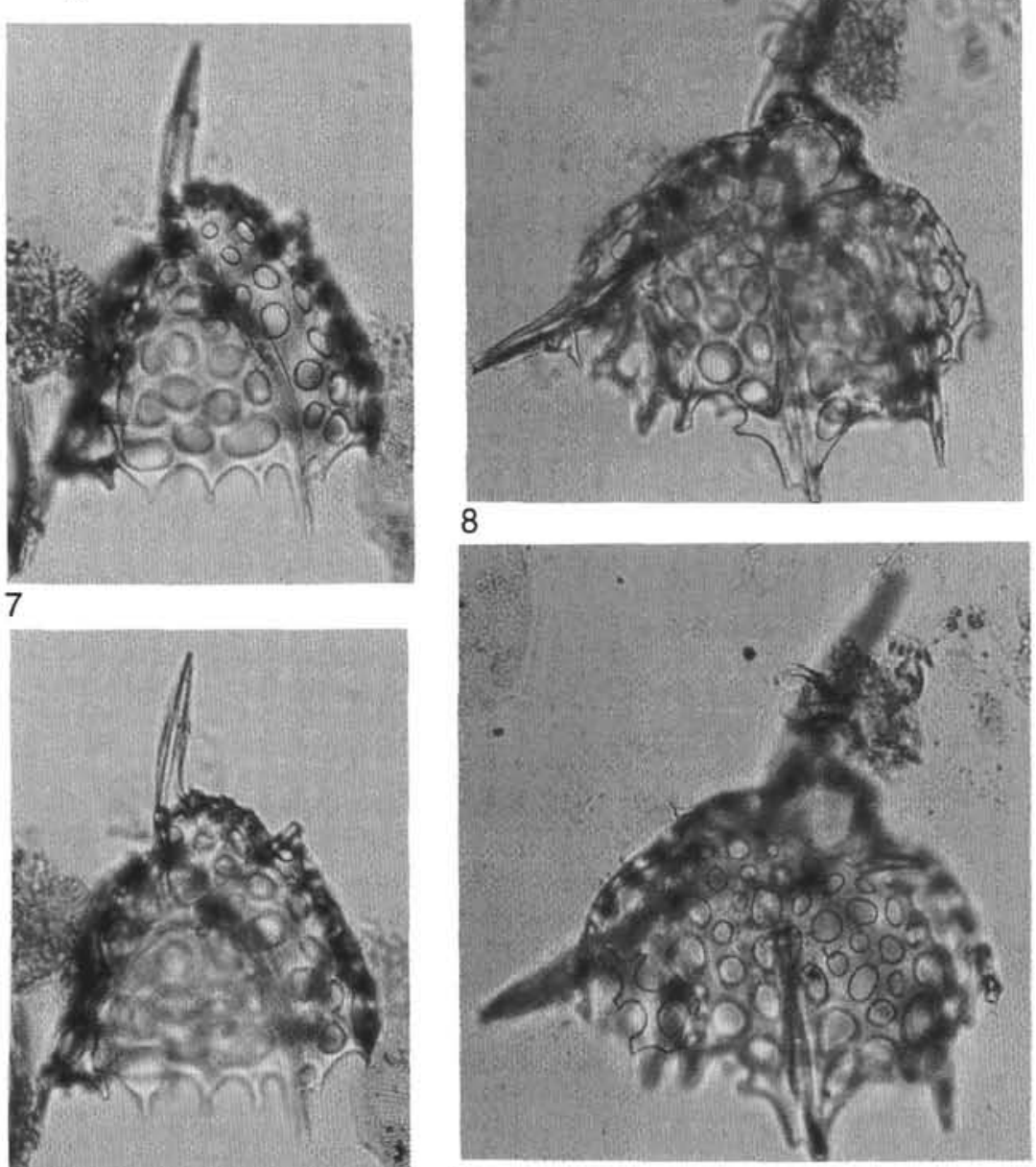

11

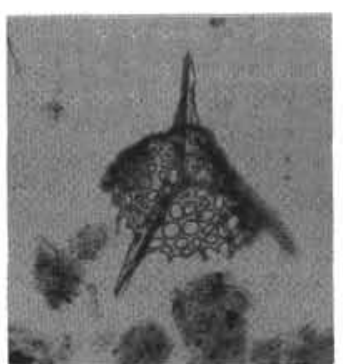

4

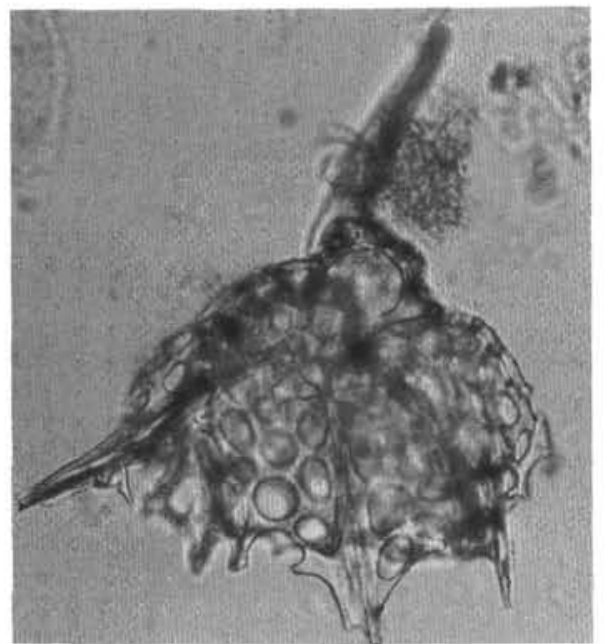

8

Plate 7. 1. Siphocampe acephala, 151-913B-26R-3, 10-12 cm; 1-M26/2 (England Finder position), 100X. 2. S. acephala, 151-913B-23R-1, 73-75 cm; 1-S18/3, 100×. 3. S. acephala, 151-913B-27R-1, 91-93 cm; 1-R27/2, 100×. 4. Pseudodictyophimus sp. B, 151-908A-32X-5, 135-137 cm; 2-015/1, 10X. 5. Siphocampe septata, 151-913B-23R-1, 73-75 cm; 1-O27/C, 100×. 6. S. septata, 151-908A-29X-7, 2-5 cm; 1-O47/C, 100×. 7, 10. Pseudodictyophimus sp. C, 151-908A$30 \mathrm{X}-2,113-115 \mathrm{~cm} ; 1-\mathrm{K} 37 / 3,100 \times, 100 \times .8$, 11. Pseudodictyophimus(?) sp. D, 151-908A-33X-1, 128-130 cm; 3-N45/4, 100×, 100×. 9. Pseudodictyophimus sp. B, 151-908A-32X-6, 126-128 cm; 1-M44/3, 100X. 


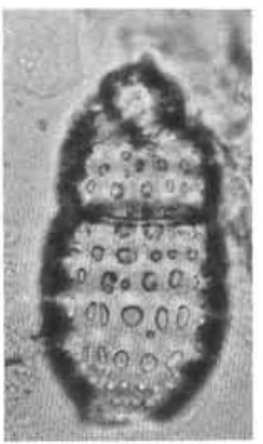

1

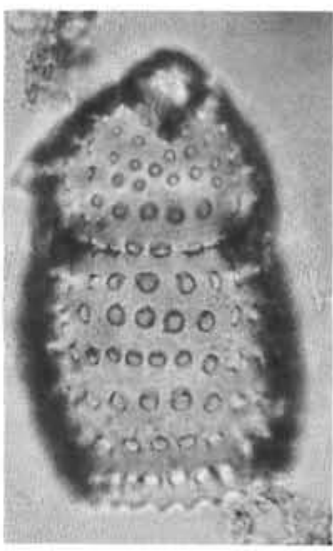

7

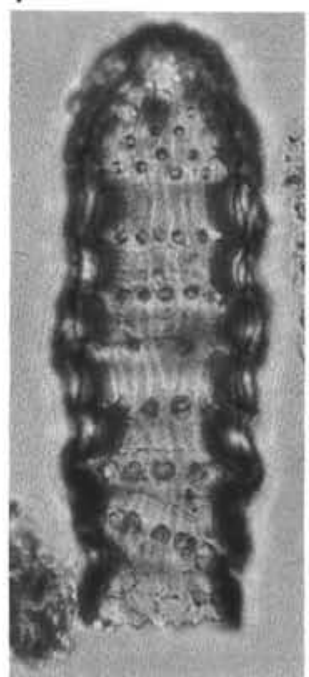

12

2
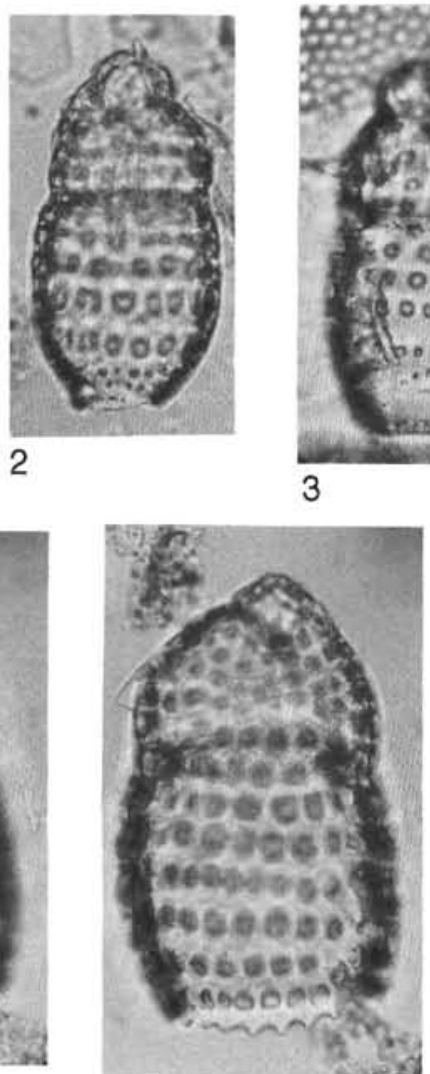

8

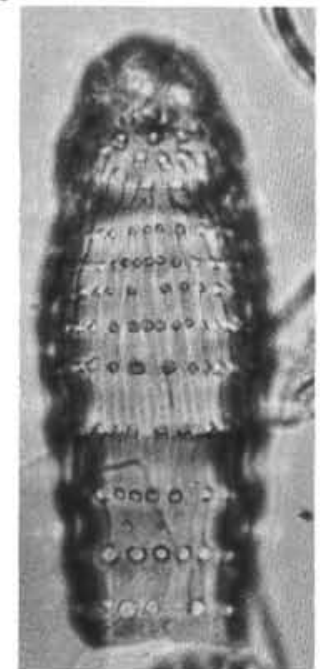

13

3
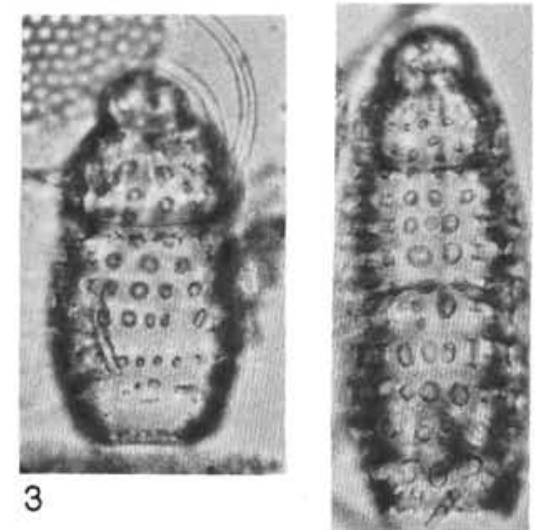

4

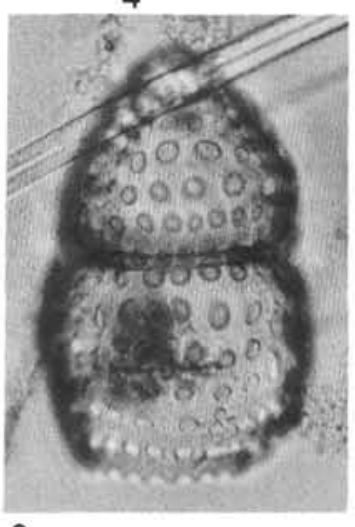

9

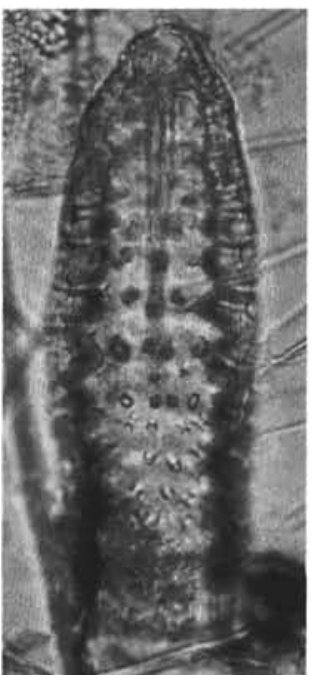

14

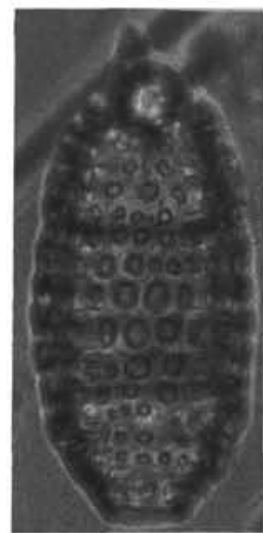

5

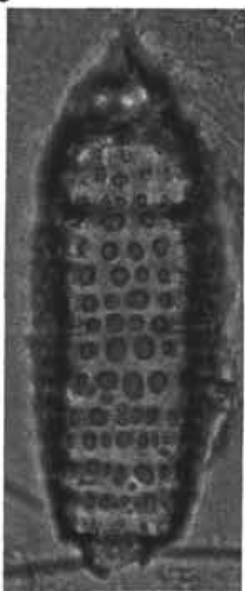

10

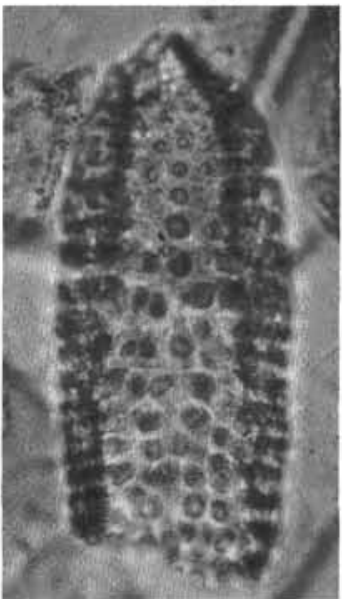

15

Plate 8. 1, 2. Siphocampe sp. cf. S. minuta, 151-913B-27R-1, 91-93 cm; 1-P28/3 (England Finder position), 100×, 100×. 3. S. sp. cf. S. minuta, 151-913B-27R3, 25-27 cm; 2-P30/1, 100×. 4. Siphocampe elizabethae, 151-913B-25R-6, 46-48 cm; 1-L25/2, 100X. 5, 6. Siphocampe sp. B, 151-913B-26R-1, 81-83 cm; 2F19/C, 100X, 100×. 7, 8. Siphocampe minuta, 151-913B-27R-4, 34-36 cm; 1-H48/1, 100X, 100X. 9. Siphocampe minuta, 151-913B-27R-4, 34-36 cm; 1-J32/2, $100 \times .10$, 11. Stylatractus sp. A, 151-913B-27R-4, 91-93 cm; 1-M33/3, 100×, 100×. 12. Siphocampe arachnea, 151-913B-19W-5, 70-75 cm; 1-J26/3, 100×. 13. Siphocampe imbricata, 151-913B-26R-1, 90-93 cm; 2-Q27/C, 100X. 14. Siphocampe stathmeporoides, 151-913B-26R-2, 118-121; 1-L17/3, 100X. 15. Siphocampe sp. aff. S. stathmeporoides, 151-913B-24R-1, 140-142 cm; 2-R37/1, 100X. 